\title{
Mari Seppälä
}

\section{Biogas Production from High-Yielding Energy Crops in Boreal Conditions}
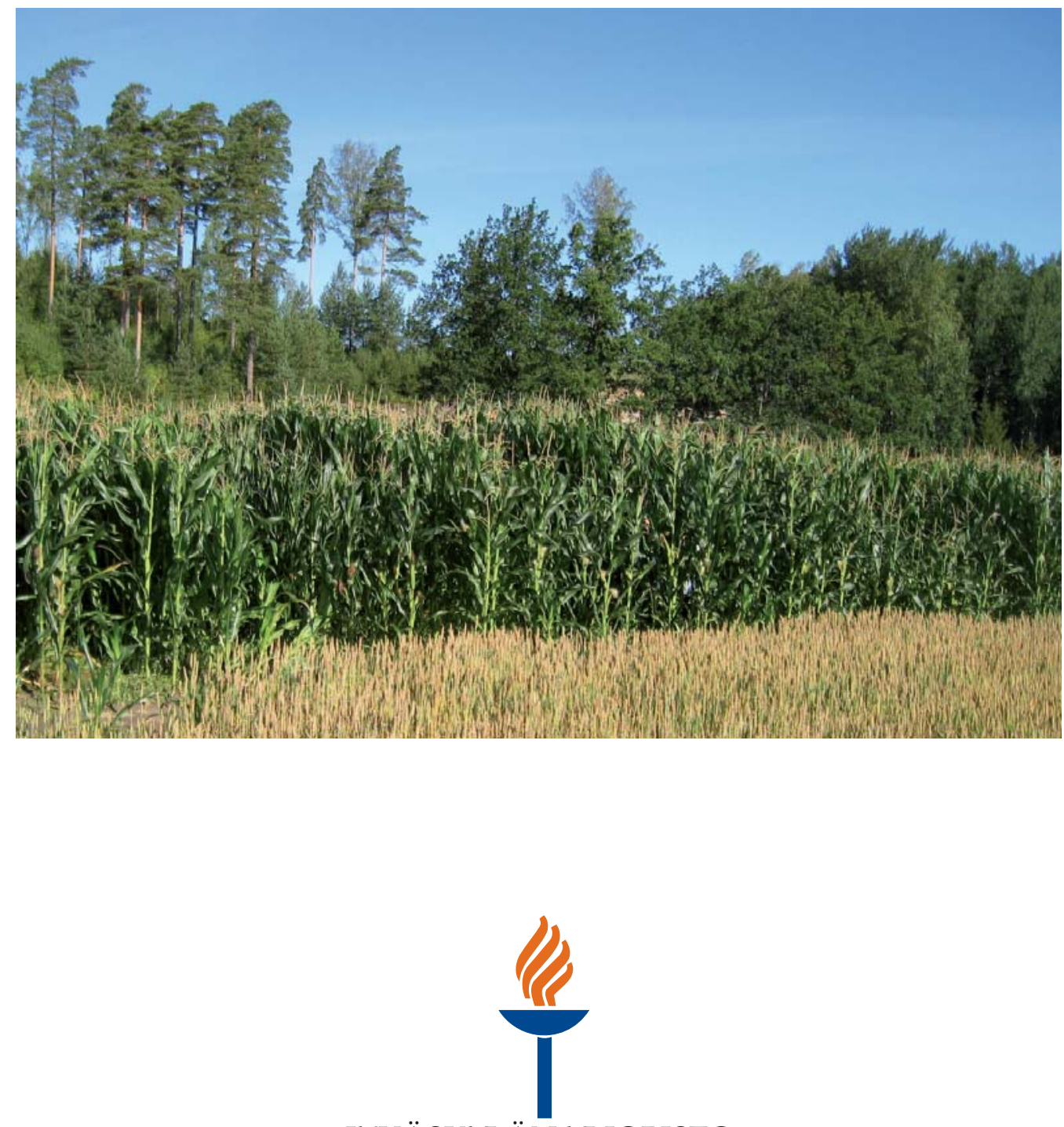


\section{Mari Seppälä}

\section{Biogas Production from High-Yielding Energy Crops in Boreal Conditions}

Esitetään Jyväskylän yliopiston matemaattis-luonnontieteellisen tiedekunnan suostumuksella julkisesti tarkastettavaksi yliopiston Ylistönrinteellä salissa YAA303 syyskuun 27. päivänä 2013 kello 12.

Academic dissertation to be publicly discussed, by permission of the Faculty of Mathematics and Science of the University of Jyväskylä, in Ylistönrinne, Hall YAA303, on September 27, 2013 at 12 o' clock noon.

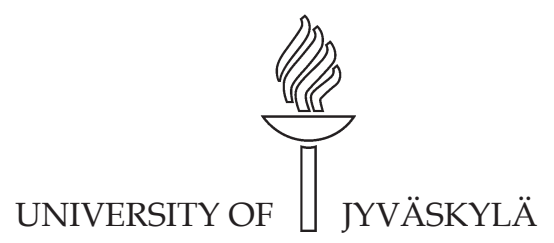

JYVÄSKYLÄ 2013 


\section{Biogas Production from High-Yielding Energy Crops in Boreal Conditions}




\section{Mari Seppälä}

\section{Biogas Production from High-Yielding Energy Crops in Boreal Conditions}

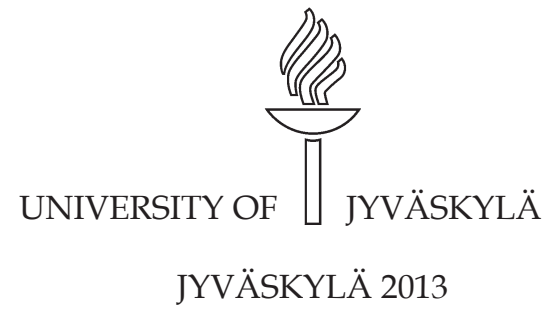


Editors

Jari Haimi, Anssi Lensu

Department of Biological and Environmental Science, University of Jyväskylä Pekka Olsbo, Sini Tuikka

Publishing Unit, University Library of Jyväskylä

Jyväskylä Studies in Biological and Environmental Science

Editorial Board

Jari Haimi, Anssi Lensu, Timo Marjomäki, Varpu Marjomäki

Department of Biological and Environmental Science, University of Jyväskylä

URN:ISBN:978-951-39-5386-7

ISBN 978-951-39-5386-7 (PDF)

ISBN 978-951-39-5385-0 (nid.)

ISSN 1456-9701

Copyright $@ 2013$, by University of Jyväskylä

Jyväskylä University Printing House, Jyväskylä 2013 


\author{
ABSTRACT \\ Seppälä, Mari \\ Biogas production from high-yielding energy crops in boreal conditions \\ Jyväskylä: University of Jyväskylä, 2013, 89 p. \\ (Jyväskylä Studies in Biological and Environmental Science \\ ISSN 1456-9701; 266) \\ ISSN 978-951-39-5385-0 (nid.) \\ ISBN 978-951-39-5386-7 (PDF) \\ Yhteenveto: Biokaasun tuotanto suurisatoisista energiakasveista pohjoisissa \\ olosuhteissa \\ Finnish summary \\ Diss.
}

In this thesis, the methane production potential of traditional and novel energy crops was evaluated in boreal conditions. The highest methane yield per hectare was achieved with maize $\left(4000-9200 \mathrm{~m}^{3} \mathrm{CH}_{4} \mathrm{ha}^{-1} \mathrm{a}^{-1}\right)$ and the second highest with brown knapweed (2 700-6 $\left.100 \mathrm{~m}^{3} \mathrm{CH}_{4} \mathrm{ha}^{-1} \mathrm{a}^{-1}\right)$. Recently, the most feasible energy crop, grass, produced $1200-3600 \mathrm{~m}^{3} \mathrm{CH}_{4} \mathrm{ha}^{-1} \mathrm{a}^{-1}$. The specific methane yields of traditional and novel energy crops varied from $170-500 \mathrm{l} \mathrm{kg}^{-1}$ volatile solid (VS). The highest specific methane yields were obtained with maize, while the novel energy crops were at a lower range. The specific methane yields decreased in the later harvest time with maize and brown knapweed, and the specific methane yield of the grasses decreased from the $1^{\text {st }}$ to $2^{\text {nd }}$ harvests. Maize and brown knapweed produced the highest total solid (TS) yields per hectare 13-23 tTS ha- $^{-1}$, which were high when compared with the TS yields of grasses (6-13 tTS ha-1). The feasibility of maize and brown knapweed in co-digestion with liquid cow manure, in continuously stirred tank reactors (CSTR), was evaluated. According to the CSTR runs, maize and brown knapweed are suitable feeds and have stable processes, producing the highest methane yields (organic loading rate $2 \mathrm{kgVS} \mathrm{m}^{-3} \mathrm{~d}^{-1}$ ), with maize at $2591 \mathrm{kgVS}^{-1}$ and brown knapweed at $254 \mathrm{l} \mathrm{kgVS}^{-1}$. The energy balance (input/output) of the cultivation of the grasses, maize and brown knapweed was calculated in boreal conditions, and it was better when the digestate was used as a fertilizer (1.8-4.8 $\%)$ than using chemical fertilizers (3.7-16.2\%), whose production is the most energy demanding process in cultivation. In conclusion, the methane production of maize, grasses and novel energy crops can produce high methane yields and are suitable feeds for anaerobic digestion. The cultivation managements of maize and novel energy crops for biogas production require further research.

Keywords: Biogas production; co-digestion; grass; maize; novel energy crops; specific methane yield; yield.

Mari Seppälä, University of Jyväskylä, Department of Biological and Environmental Science, P.O. Box 35, FI-40014 University of Jyväskylä, Finland 


\author{
Author's address Mari Seppälä \\ Department of Biological and Environmental Science \\ P.O. Box 35 \\ 40014 University of Jyväskylä \\ Finland \\ mari.seppala@hotmail.com \\ Supervisors \\ Professor Jukka Rintala \\ Department of Chemistry and Bioengineering \\ Tampere University of Technology \\ P.O. Box 541 \\ FI-33101 Tampere \\ Finland \\ University Lecturer Prasad Kaparaju \\ Department of Biological and Environmental Science \\ P.O. Box 35 \\ FI-40014 University of Jyväskylä \\ Finland

\begin{tabular}{|c|c|}
\hline \multirow[t]{2}{*}{ Reviewers } & $\begin{array}{l}\text { Dr. Jerry D. Murphy } \\
\text { Environmental Research Institute } \\
\text { University College Cork } \\
\text { Lee Road } \\
\text { Cork } \\
\text { Ireland }\end{array}$ \\
\hline & $\begin{array}{l}\text { Professor Perttu Virkajärvi } \\
\text { MTT, Animal Production Research } \\
\text { Halolantie } 31 \text { A } \\
\text { FI-71750 Maaninka } \\
\text { Finland }\end{array}$ \\
\hline Opponent & $\begin{array}{l}\text { Professor Liisa Viikari } \\
\text { Department of Food and Environmental Sciences } \\
\text { University of Helsinki } \\
\text { P.O. Box } 27 \\
\text { FI-00014 Helsinki } \\
\text { Finland }\end{array}$ \\
\hline
\end{tabular}




\section{CONTENTS}

\section{LIST OF ORIGINAL PUBLICATIONS}

ABBREVIATIONS

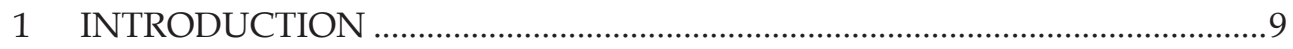

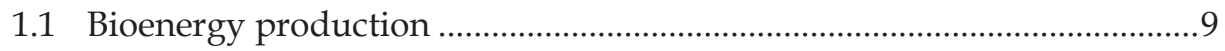

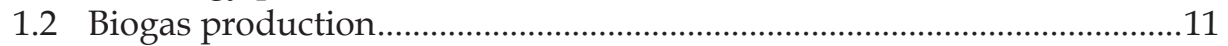

1.2.1 Methane production via the anaerobic digestion process...............11

1.2.2 Composition of energy crops ...........................................................12

1.2.3 Anaerobic co-digestion of energy crops ...........................................14

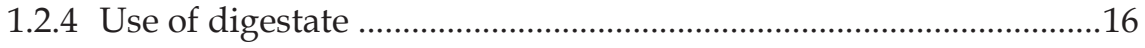

1.3 Energy crops for biogas production .............................................................17

1.3.1 Energy crops and novel energy crops for biogas production in boreal conditions............................................................................17

1.3.2 Energy balance and greenhouse gas emissions of the biogas plant using energy crops .......................................................................2

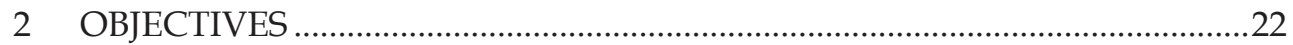

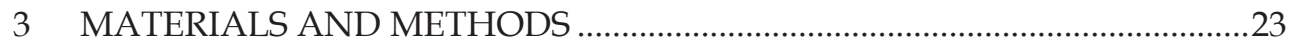

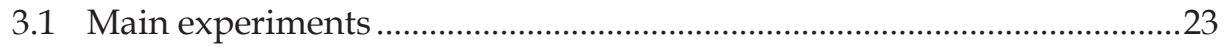

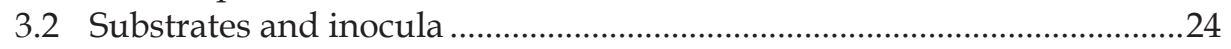

3.2.1 Grass material (I) .........................................................................2.

3.2.2 Maize material (II, III) ...................................................................... 24

3.2.3 Novel energy crops (IV) …………………….................................2

3.2.4 Handling of crop materials .................................................................28

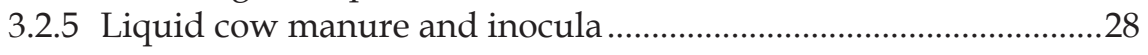

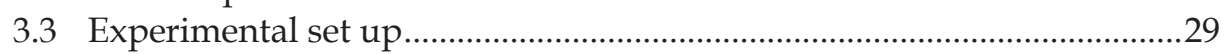

3.3.1 Methane potential assays (I-IV) .......................................................29

3.3.2 Co-digestion experiments (III, IV) ................................................29

3.3.3 Post-methanation assays (III, IV) .......................................................30

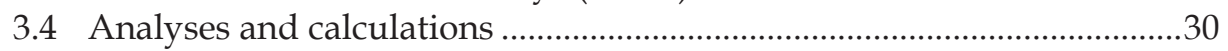

3.5 Energy balance of cultivation energy crops for biogas production .........32

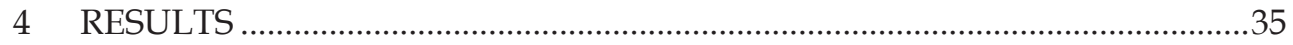

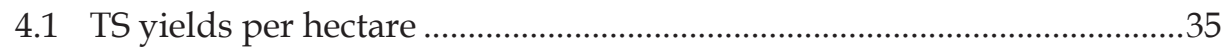

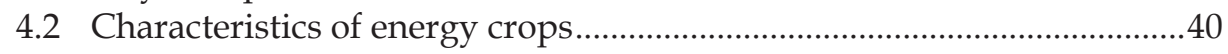

4.3 Specific methane yields.............................................................................4

4.3.1 Specific methane yields of grasses.................................................... 41

4.3.2 Specific methane yields of maize varieties ..........................................42

4.3.3 Specific methane yields of novel energy crops ..................................42

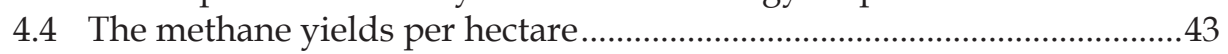


4.5 Co-digestion of maize and brown knapweed with liquid cow manure

4.6 Energy balance of cultivation energy crops for biogas production .........54

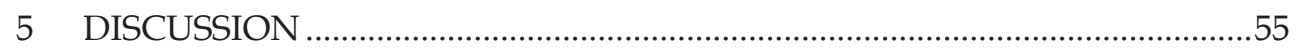

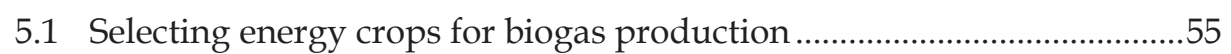

5.2 Methane production of energy crops in boreal conditions .......................60

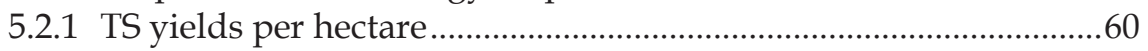

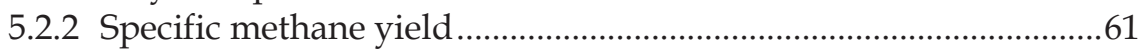

5.2.3 The methane yield per hectare ..............................................................64

5.3 Co-digestion of maize or brown knapweed with liquid cow manure in the CSTR process ........................................................................67

5.3.1 Methane yields and post-methanation potential...............................67

5.3.2 Nutrients and trace elements of the feed and digestate ..................70

5.4 Energy balance of cultivation energy crops for biogas production in

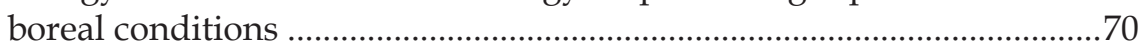

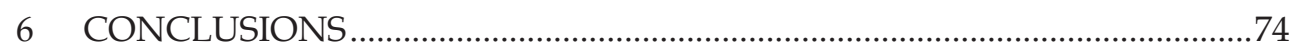

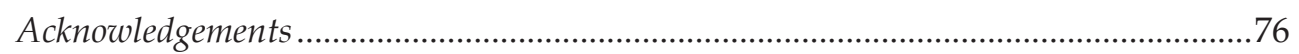

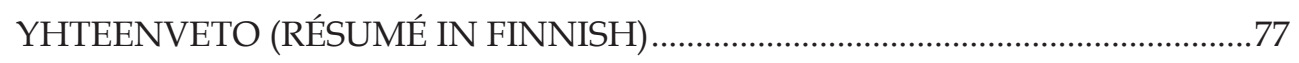

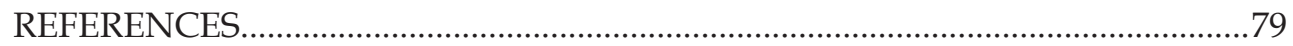




\section{LIST OF ORIGINAL PUBLICATIONS}

The thesis is based on the following original articles, which will be referred to in the text by their Roman numerals I-IV.

I planned the experimental work with my co-authors and did the main part of the experimental work. I wrote the first draft of the all papers and finalized them with my co-authors.

I Seppälä M., Paavola T., Lehtomäki A. \& Rintala J. 2009. Biogas production from boreal herbaceous grasses - Specific methane yield and methane yield per hectare. Bioresource Technology 100: 2952-2958.

II Seppälä M., Pyykkönen V., Laine A. \& Rintala J. 2012. Methane production from maize in Finland - Screening for different maize varieties and plant parts. Biomass and Bioenergy 46: 282-290.

III Seppälä M., Pyykkönen V., Väisänen A. \& Rintala J. 2013. Biomethane production from maize and liquid cow manure - Effect of share of maize, post-methanation potential and digestate characteristics. Fuel 107: 209-216.

IV Seppälä M., Laine A. \& Rintala J. 2013. Screening of novel plants for biogas production in northern conditions. Bioresource Technology 139: 355-362. 


\section{ABBREVIATIONS}

$\begin{array}{ll}\text { ADF } & \text { acid detergent fibre } \\ \text { ANOVA } & \text { analysis of variance } \\ \text { EU } & \text { European Union } \\ \text { CHP } & \text { combined heat and electricity production } \\ \text { CSTR } & \text { continuously stirred tank reactor } \\ \text { DAS } & \text { days after sowing } \\ \text { FAO } & \text { Food and Agriculture Organization } \\ \text { FR } & \text { feeding regime } \\ \text { GHG } & \text { greenhouse gas } \\ \text { ha } & \text { hectare } \\ \text { HRT } & \text { hydraulic retention time } \\ \mathrm{K}_{\text {tot }} & \text { total potassium } \\ \mathrm{N}_{\text {tot }} & \text { total nitrogen } \\ \text { NDF } & \text { neutral detergent fibre } \\ \text { NHH} \\ \text {-N } & \text { ammonium nitrogen } \\ \text { OLR } & \text { organic loading rate } \\ \mathrm{P}_{\text {tot }} & \text { total phosphorus } \\ \text { RCG } & \text { reed canary grass } \\ \text { SCOD } & \text { soluble chemical oxygen demand } \\ \text { SD } & \text { standard deviation } \\ t & \text { metric ton } \\ \text { TS } & \text { total solids } \\ \text { VFA } & \text { volatile fatty acid } \\ \text { VFA } & \text { total volatile fatty acid } \\ \text { VS } & \text { volatile solid } \\ \text { WW } & \text { wet weight } \\ \end{array}$




\section{INTRODUCTION}

\subsection{Bioenergy production}

The targets of renewable energy production are to reduce fossil fuel usage and greenhouse gas (GHG) emissions, increase energy use efficiency and decrease fossil fuel energy import dependency, diversify sources of renewable energy production, and contribute to sustainable development (Resch et al. 2008, Smyth et al. 2009, Singh et al. 2010). The European Union (EU) has set the targets for the use of renewable energy, and the goal to increase the use of renewable energy in vehicles is set by the European Commission Renewable Energy Directive $(2009 / 28 / E C)$ (European Union 2009). In 2020, the share of renewable energy in the whole energy production should be at least $20 \%$, under EU member countries, and 38 \% in Finland (European Union 2009, TEM 2010, TEM 2013). The share of renewable energy in the transportation sector should be $10 \%$ in 2020 in each EU member country (European Union 2009).

Renewable energy consists of solar and wind energy, hydropower, geothermal heat and bioenergy. Bioenergy is produced from biomass, like woodbased fuels, energy crops, manures and organic wastes and residues. Bioenergy can be produced through thermal conversion of energy crops, wood and woodbased fuels, making biodiesel or bioethanol from energy crops and organic wastes, and producing biogas through anaerobic digestion from energy crops, manures and organic wastes.

Anaerobic digestion produces both biogas (consisting of methane, $\mathrm{CH}_{4}, 45$ $70 \%$ and carbon dioxide, $\mathrm{CO}_{2}, 25-50 \%$ ) and digestate, the process residue. Biogas can be used as for combined heat and electricity production (CHP) or upgraded to biomethane to be injected into the gas grid or used as biofuel in transportation (Fig. 1). Interest in producing biogas from crops has increased in recent years, because of available field areas and the higher methane yield of crops than manure, which is traditionally used for biogas production with sewage sludge (Weiland 2010). The number of biogas plants has increased rapidly, for example, in Germany there were 7500 biogas plants, in which the net electricity 
production was $21.6 \mathrm{TWh}^{-1}$ (installed electric power was almost $3200 \mathrm{MW}$ ) in the year 2012 (FNR 2013a,b). Almost all biogas plants in Germany use energy crops as substrates and over $90 \%$ of German biogas plants used maize (Zea mays L.) as a substrate in 2006 (Weiland 2010). The biogas plants utilised approximately 962000 ha of agricultural land area (8.2 \% of the field area) in the year 2012 in Germany (FNR 2013a,b). The field area of the energy crops was 2124500 ha, including rapeseed for biodiesel production (913000 ha) and sugar and starch crops for bioethanol production in Germany in 2012 (243 000 ha) (FNR 2013a). In 2011, the biogas plants in Austria totalled 600, of which 350 were agriculturally orientated (Drosg 2012). In Finland, there are 10 biogas plants on farms and 14 biogas plants were in the planning stages in 2011 (Huttunen \& Kuittinen 2012).

The energy crops can be divided in two groups, sugar and starch crops, and lignocellulosic crops. Sugar and starch crops, like wheat, barley, and rapeseed, can also be used for food and feed production. Using lignocellulosic crops (miscanthus, switchgrass, giant reed, and poplar), agricultural wastes and residues (straws, leaves, stover) and forestry feedstock for bioenergy production, increases the efficiency of sustainable renewable energy production (Christou et al. 2010, Frigon \& Guiot 2010). Lignocellulosic materials consist mainly of three different types of polymers, cellulose, hemicellulose and lignin, which are associated with each other (Hendrick \& Zeeman 2009).

The biogas production chain, through the anaerobic digestion from energy crops, is presented in Fig. 1. Before the biogas process begins, the crop or plant material must be harvested, the particle size reduced and the material stored with a preservative. Energy crops must be stored so that energy can be produced throughout the whole year. Ensiling is a traditional way to store fodder crops for animal feed, which has also proved to be a suitable method for storing energy crops for biogas production (Pakarinen et al. 2008, 2011b). In cultivating plants and crops for biogas production, the nutrient cycle is almost closed, because the digestate can be used as a fertilizer in the fields growing the energy crops, plants and residues for the reactor (Fig. 1). 


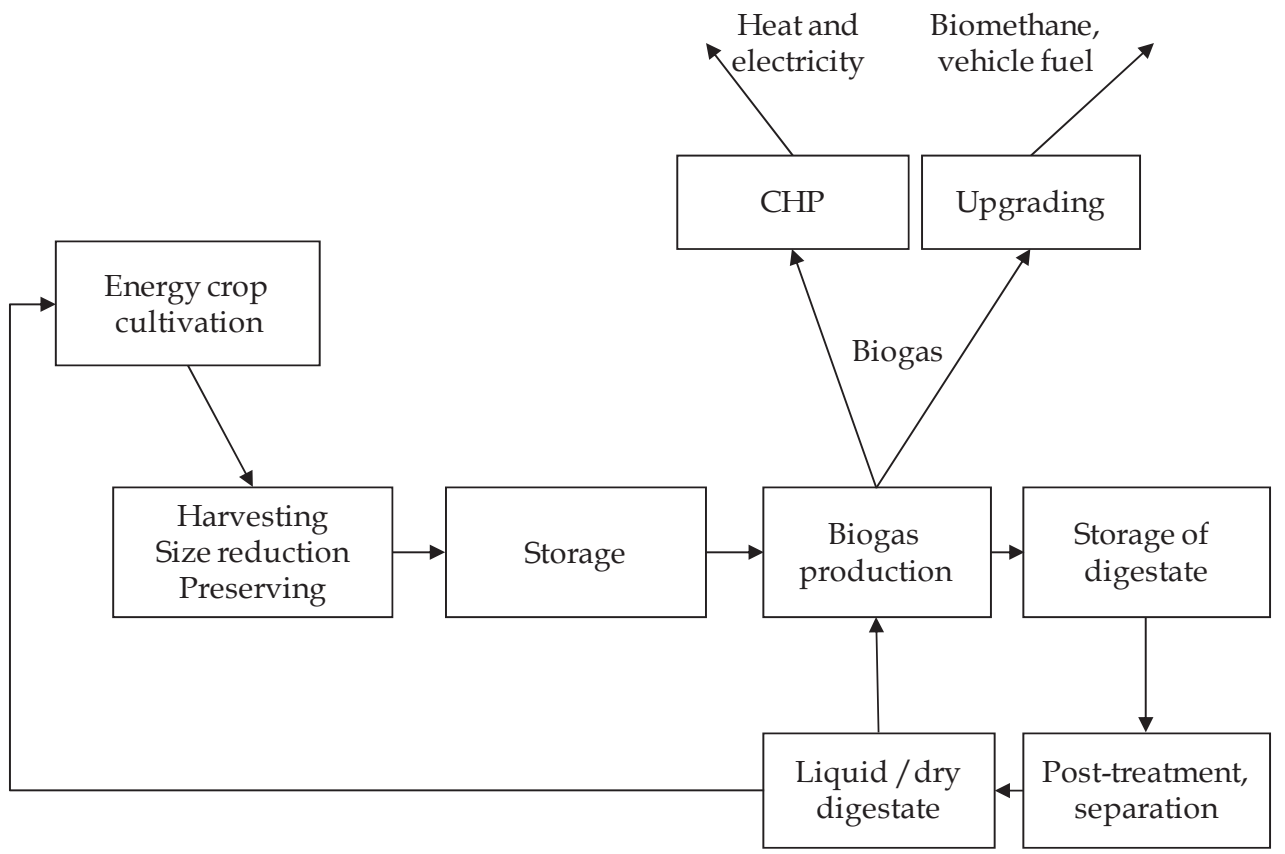

FIGURE 1 Biogas production chain from energy crops and plants producing heat and power, or biomethane for vehicle fuel, using digestate as a fertilizer for crops and plants.

\subsection{Biogas production}

\subsubsection{Methane production via the anaerobic digestion process}

Methane production via the anaerobic digestion of solid substrates is usually divided into four main phases, namely: hydrolysis, acidogenesis, acetogenesis and methanogenesis (Fig. 2). The first phase of the entire process involves feeding the energy crops into the digester. Crops consist of carbohydrates, proteins and fats, which are degraded by enzymes into soluble compounds (short chain sugars, amino acids and fatty acids). The hydrolysis of carbohydrates occurs within a few hours, but with protein and fats it takes a number of days (Deublein \& Steinhauser 2012). Hydrolysis is often the rate limiting phase for anaerobic digestion, in cases when the substrate is in particulate form (Meulupas et al. 2005). Lignocellulose and lignin are degraded slowly and incompletely, but the methane production of lignocellulosic biomass can be enhanced with different pre-treatments (Hendrick \& Zeeman 2009). 


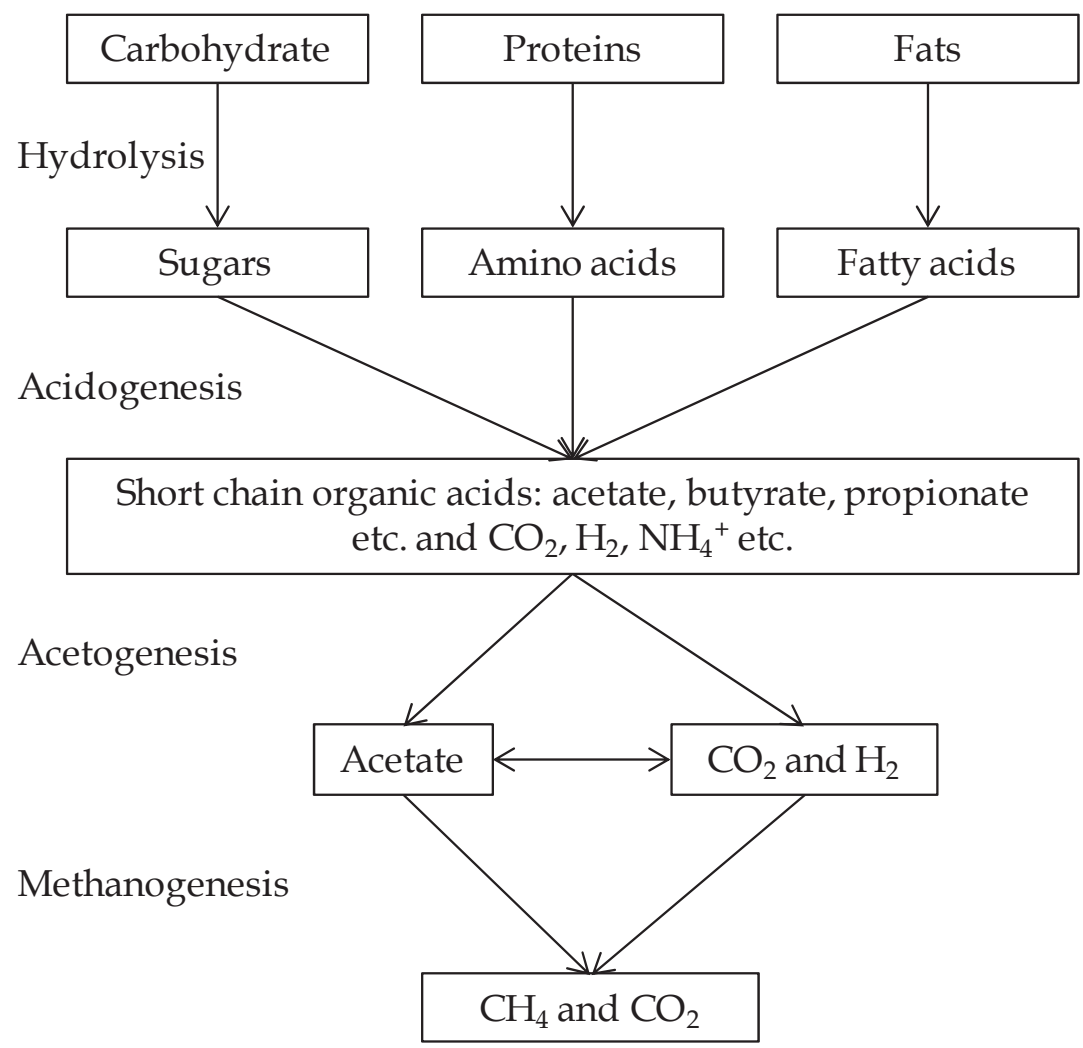

FIGURE 2 Methane production via the anaerobic digestion process from polymeric substrates. (Modified from Madsen et al. 2011, Deublein \& Steinhauser 2012).

In the second phase, acidogenesis, the sugars, amino acids and fatty acids are degraded (oxidized) to short chain organic acids (acetate, butyrate, propionate etc.), hydrogen $\left(\mathrm{H}_{2}\right)$ and $\mathrm{CO}_{2}$ by fermentative bacteria. Due to the variety of starting compounds, this phase is carried out by a diverse group of microorganisms. In acetogenesis, the third phase, the short chain organic acids are oxidized by acetogenic bacteria to acetate, $\mathrm{CO}_{2}$ and $\mathrm{H}_{2}$, which are used as substrates in the methanogenesis phase. In the fourth and final phase, methanogenesis (methane formation) takes place under strictly anaerobic conditions (carbonate respiration). In this way, the carbon in the biomass is converted into $\mathrm{CO}_{2}$ and $\mathrm{CH}_{4}$. When methane formation is distributed, acidification occurs, and approximately $2 / 3$ of the methane produced in an anaerobic digester comes from acetate.

\subsubsection{Composition of energy crops}

Chemical composition affects the biodegradability and specific methane yield of energy crops and plants (Amon et al. 2007b). Plant biomass is mainly composed of cellulose, hemicellulose and lignin, along with smaller amounts of protein, pectin, soluble non-structural materials (sugars, nitrogenous material, 
chlorophyll and waxes) and inorganic minerals (McKendry 2002, Chandra et al. 2012) (Fig. 3). The highest theoretical specific methane yield is calculated to be from lipids, on average, at $9301 \mathrm{~kg}$ volatile solid (VS)-1 (Herrmann \& Rath 2012). The theoretical specific methane yield of protein is, on average, $4741 \mathrm{kgVS}^{-1}$ and for carbohydrates it is $4051 \mathrm{kgVS}^{-1}$ (Herrmann \& Rath 2012). Many factors influence the chemical composition of plants, including harvest time, growth stage, plant type, leaf/stem ratio, growing conditions and fertilization. To achieve a high specific methane yield, crop substrates need to be low in lignin content and have a high content of easily degradable components, such as nonstructural carbohydrates, soluble carbohydrates and soluble cell components (Chynoweth et al. 1993, Amon et al. 2007b, Schittenhelm 2008). An ideal substrate for anaerobic digestion will contain high amounts of degradable carbohydrates (sugars), lipids and proteins, and, at the same time, have a low concentration of lignin and cellulose.

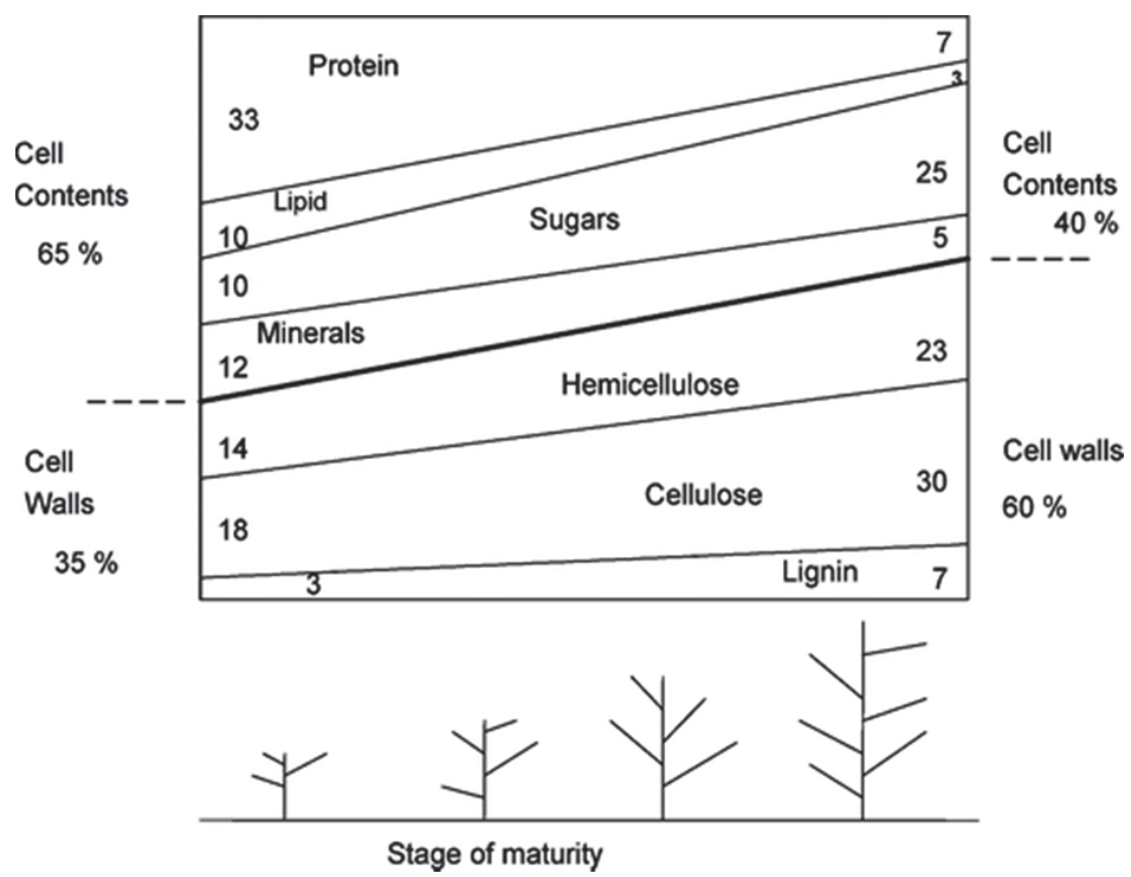

FIGURE 3 Chemical composition of grass with advancing maturity (Holmes 1980).

Typically, cellulose accounts for $40-50 \%$ of the plant material by weight, while hemicellulose accounts for $20-40 \%$. Cellulose is a linear polymer of glucose molecules attached via $\beta$-1,4-linkages, and contains both disorganized, amorphous structures and crystalline (organized) structures, which are considered to be more difficult to degrade. Hemicellulose is a complex carbohydrate structure that consists of different polymers, such as pentose, hexose, sugar acids and xylan, which is the most common hemicellulose component in grass (Hendriks \& Zeeman 2009). Hemicellulose is more soluble 
than cellulose; however, both cellulose and hemicellulose can be anaerobically converted to methane. The rate of degradation, especially of cellulose, strongly depends on its state in the feedstock. If the cellulose is mainly in a crystalline form, the cellulases can attach to it and hydrolysis can occur rapidly, but if the cellulose is lignin-encrusted, the lignin prevents the access of cellulases to the cellulose fibres (Klimiuk et al. 2010). Lignin is, after cellulose and hemicellulose, one of the most abundant polymers in nature, and is present in the cellular wall to provide plants with structural support. It has a high molecular weight and an amorphous heteropolymer consisting of three different phenylpropane units. Lignin is also water-insoluble and optically inactive, all of which make the degradation of lignin very difficult (Hendriks \& Zeeman 2009).

The composition of the plants varied among, the species, developmental stage (Fig. 3), fertilization and storage methods. The \% total solid (TS) of cellulose, hemicellulose and lignin in reed canary grass stems was $40 \%, 30 \%$ and $10 \%$, and $25 \%, 35 \%$ and $4 \%$ in the leaves when harvesting in August (Kandel et al. 2013). The chemical composition of maize 160 days after sowing was $18 \%$ water soluble carbohydrates, $10 \%$ starch, $25 \%$ hemicellulose, $27 \%$ cellulose and 3 \% lignin (Schittenhelm 2008).

Chopping up the harvested plants and crops helps to break down the lignocellulose structures for anaerobic digestion, and may lead to a better digestibility of the fibre fraction of the plants. A high protein concentration, on the other hand, may lead to process failure due to an accumulation of ammonia (Prochnow et al. 2009). Biogas plants can degrade cellulose to a much greater extent than ruminants, partly because the hydraulic retention time in biogas plants is longer, and the population of microorganisms is different than in ruminants.

\subsubsection{Anaerobic co-digestion of energy crops}

Crop and plant biomass from the fields can be digested either alone, or in codigestion with other materials. The biogas process can be either a wet $(\mathrm{TS}<15 \%)$ or dry (TS $>15 \%$ ) process. In the co-digestion of crop biomass and manure, the manure provides a buffering capacity, a wide range of nutrients, and the TS content is low (TS $<10 \%$ ), offering enough water for the process and microbes. This is why most of the biogas plants in the agricultural sector use manure and energy crops in wet processes, mainly in continuously stirred tank reactors (CSTRs). Manure is an easily available resource on farms, but has a low content of VS, and the low biogas yield concluding high investment cost, which does not make the production of biogas from manure economically feasible (Gerin et al. 2008, Weiland 2010). The manure has already passed through the digestive tract of the animal, and most of the energy rich substances, like carbohydrates and proteins, have already been digested. Still, the average share of manure was $37 \%$ TS \% in the biogas plants in Germany (FNR 2009).

Biogas production can be greatly improved by using energy rich cosubstrates, such as energy crops, crop residues, industrial by-products and other biodegradable wastes, in anaerobic digesters. Currently, biogas production from 
energy crops is based mainly on the anaerobic digestion of maize (Amon et al. 2007a,b, Schittenhelm 2008, Weiland 2010), but fodder, sugar beets, grass silages and grain crops have also been used and studied in biogas processes (Amon et al. 2007a,b, Lehtomäki et al. 2008). The co-digestion of animal manure with straw from various cereals and fodder crops (Somayaji \& Khanna 1994, Lehtomäki et al. 2007), with energy crops (Kaparaju et al. 2002, Lehtomäki et al. 2007, Giuliano et al. 2013) and with maize (Fujita et al. 1980, Cornell et al. 2008, 2011) has been reported. Additionally, some challenges have been identified with the anaerobic processes of grass. Grass tends to float upon the surface in the digester, leading to increased stirring expenses and the longer grass particles wrap around moving devices, which can cause failures and problems in biogas plants (Prochnow et al. 2009).

The efficient and reliable process technology and energy production per unit requires the use of high organic loading rate (OLR) and short hydraulic retention time (HRT). There has been little research into the co-digestion of feedstock with a high share of the energy crops. One research study was done with energy crops when the share of the crop was 40-60\% of the VS of the feedstock (Lehtomäki et al. 2007). Co-digestion with maize and manure has been carried out using different proportions of maize, and using various HRTs and OLRs (Cornell et al. 2008, 2011), but the post-methanation potential of the digestate was not measured in any of these studies (Cornell et al. 2008, 2011).

The post-methanation potential is important because it describes the methane potential of the digestate, and some of the energy yield which would be lost from the methane yield of the digestate. The amount of the post-methanation potential of the digestate mainly depends on the organic matter content and quality of digestate, and the operation conditions of the biogas plant (Menardo et al. 2011). It has been shown that it is possible to increase OLR in conventional biogas plants, which use manure and energy crops (Comino et al. 2010, Menardo et al. 2011). If the biogas plant has a high OLR and a short HRT, the digestate will still contain a considerable amount of undigested organic matter, and a significant amount of methane would be lost to the atmosphere. Covering the digestate storage is economically attractive, because large amounts of energy can be collected and sold (Menardo et al. 2011).

In order to maximize the yield of the produced methane, necessary nutrients and trace elements must be present in the reactor, which allows the use of higher OLRs and lower HRTs to obtain a higher methane production (Lebuhn et al. 2008, Schattauer et al. 2011). Low methane yields, acidification and process instability in crop mono-digestion lead to the application of low OLRs and long HRTs (Lebuhn et al. 2008). To achieve the high rates of methane production, trace elements are needed so that the micro-organisms are supplied with essential nutrients (Lebuhn et al. 2008, Schattauer et al. 2011). The lack of trace elements has been demonstrated, generally occuring in biogas plants which use only one substrate (mono-digestion), like energy crops (maize, grass silage) or waste (Lebuhn et al. 2008). The anaerobic digestion and microbial growth is dependent on the availability and/or optimal supply of nutrients and trace elements (Demirel \& Scherer 2011). 
One important process requirement is carbon/nitrogen $(\mathrm{C} / \mathrm{N})$ ratio. $\mathrm{A} C / \mathrm{N}$ ratio from 20 to 30 is considered optimum for anaerobic digestion process (Demirel \& Scherer 2011). Substrates with a C/N ratio that is too low lead to increase ammonia production and the inhibition of methane production. If the $\mathrm{C} / \mathrm{N}$ ratio is high, methanogens will rapidly consume the $\mathrm{N}$ for their protein requirements, and will no longer react with the left-over carbon to produce methane. In previous studies, the $\mathrm{C} / \mathrm{N}$ ratio of maize was between 24 and 51, with an increase towards maturity (Amon et al. 2007b), while in grasses it was between 15 and 22 (Lehtomäki et al. 2008). Macronutrients, such as, N, phosphorus $(\mathrm{P})$, and sulphur $(\mathrm{S})$, have been reported to act as buffering agents in the process, and trace elements, such iron $(\mathrm{Fe})$, nickel $(\mathrm{Ni})$, cobalt $(\mathrm{Co})$, molybdenum (Mo), selenium (Se), zinc ( $\mathrm{Zn})$ and copper (Cu), have an effect on the enzymes in the anaerobic digestion process (Demirel \& Scherer 2011, Nges \& Björnsson 2012).

A deficiency in the trace elements, including $\mathrm{Fe}, \mathrm{Co}, \mathrm{Ni}$, tungsten $(\mathrm{W})$ and Mo, has been shown to cause a reduction in the microbial degradation chain, while adding these nutrients has been shown to improve the performance of the anaerobic digestion of the energy crops (Hinken et al. 2008, Pobeheim et al. 2010, Nges et al. 2012). Adding trace elements to the biogas process has been shown to increase the methane production of the process (Nges et al. 2012, Nges \& Björnsson 2012, Vintiloiu et al. 2012). The requirements for a better nutrient balance can be achieved by the co-digestion of energy crops with manure, which contains more trace elements (Cavinato et al. 2010), and with a large variation of feedstock, including different variations of organic wastes, which seems to improve the abundance of trace elements (Schattauer et al. 2011).

\subsubsection{Use of digestate}

Biogas production is an almost closed nutrient cycle, when the residue from anaerobic digestion, digestate, is used to fertilize energy crop fields (Fig. 1). After the biogas processes, the digestate is transferred to storage tanks where the degradation process is finished. The most common way is to use digestate as a fertilizer in fields, but it can also be dehydrted and separated into liquid and solid phases. Typically, nitrogen is associated with the liquid portion, and 45-80 $\%$ of the $\mathrm{N}$ is present as ammonium nitrate. Most of the phosphorus is allocated into the solid portion (Möller \& Müller 2012). Digestate is often more viscous, homogeneous and less odorous than the original feedstock, making it easier to handle and spread. The economic and ecological benefits of using digestate as a fertilizer are high when compared with the fertilization of animal manure that is supplied with additional synthetic fertilizers (Vaneeckhaute et al. 2013).

Anaerobic digestion is known to inactivate weed seeds, plant pathogens and pests, and it decreases the amount of phytotoxic compounds present (Alburquerque et al. 2012). Digestate is a mixture of partially degraded organic material, microbial biomass and inorganic compounds, while it contains the same quantities of macronutrients $(\mathrm{N}, \mathrm{P}$ and $\mathrm{K})$ and trace elements as the original feedstock. During anaerobic digestion, some of the organic nitrogen supplied in 
the feed is converted into ammonium, which is readily available to crops. The digestate may have phytotoxic effects, but there are contradictory results in the previous research (Möller \& Müller 2012). The digestate can be directly applied to agricultural fields, and it should be applied at root level or injected into the soil to minimize the risk of ammonia emissions and gaseous loses by the nitrification of the ammonium to nitrate in the atmosphere (Möller \& Müller 2012, Quakernack et al. 2012). By using the digestate, instead of liquid animal manure as a fertilizer, crop growth and yield rates have been increased (or at least kept at the same level), the $\mathrm{N}$ availability to the crops has increased, and digestate handling and allocation are easier than fertilizing with manure (Möller \& Müller 2012, Quakernack et al. 2012). There have been no differences shown in the $\mathrm{P}, \mathrm{S}$ and heavy metal availability and solubility, or the $\mathrm{pH}$, with liquid cow manure and digestate (Möller \& Müller 2012).

\subsection{Energy crops for biogas production}

\subsubsection{Energy crops and novel energy crops for biogas production in boreal conditions}

The length of the growing season varies from north to south, and in the Nordic countries, such as Finland (with a growing season of 5-6 months, and heat summation of $900-1300{ }^{\circ} \mathrm{C}$ degree days), crops with a short growing season must be chosen. Food crops and energy crops must have a good tolerance to snow, low temperatures and long photoperiod. Perennial grasses (e.g., timothy, Phleum pratense L., meadow fescue, Festuca pratensis Huds.) are the most efficient producers of biomass in boreal conditions (Hyytiäinen et al. 1999). Perennial grasses are commonly cultivated as forage in boreal conditions and grasses have the advantage of being familiar to farmers and suitable for harvesting and storing with existing methods and machinery. Because grasses are bred for animal feed, they are often characterized by good digestibility. The per hectare digestibility (D-value) and TS yields of grasses have been studied carefully to ensure optimal harvest time for animal feed, with regard to optimal digestibility and high TS yield per hectare (Fig. 4) (Rinne et al. 2010). Grasses take up nutrients efficiently, and soil is covered in autumn and winter by grasses, which decrease erosion and nutrient leaching (Hyytiäinen et al. 1999). In addition, grasses often represent the cheapest biomass feedstock to produce (McEniry et al. 2011). The botanical composition of the grassland, environmental factors (soil fertility, precipitation) and cultivation factors (fertilization, harvest date) can have a significant impact on herbage chemical composition, specific methane yield and TS yield per hectare.

The biogas production of grasses has been considered to be one way to produce indigenous biofuel, biomethane, with environmental and economic consideration in Ireland, where the grasses are cultivated in over $90 \%$ of the field areas (Murphy \& Power 2009, Smyth et al. 2009, Korres et al. 2010, Smyth et al. 
2010). According to Prochnow et al. (2009), in developed countries, the production of biogas from surplus grassland has high potential for bioenergy to contribute to maintaining biodiversity, and at the same time create an economic incentive for farmers.

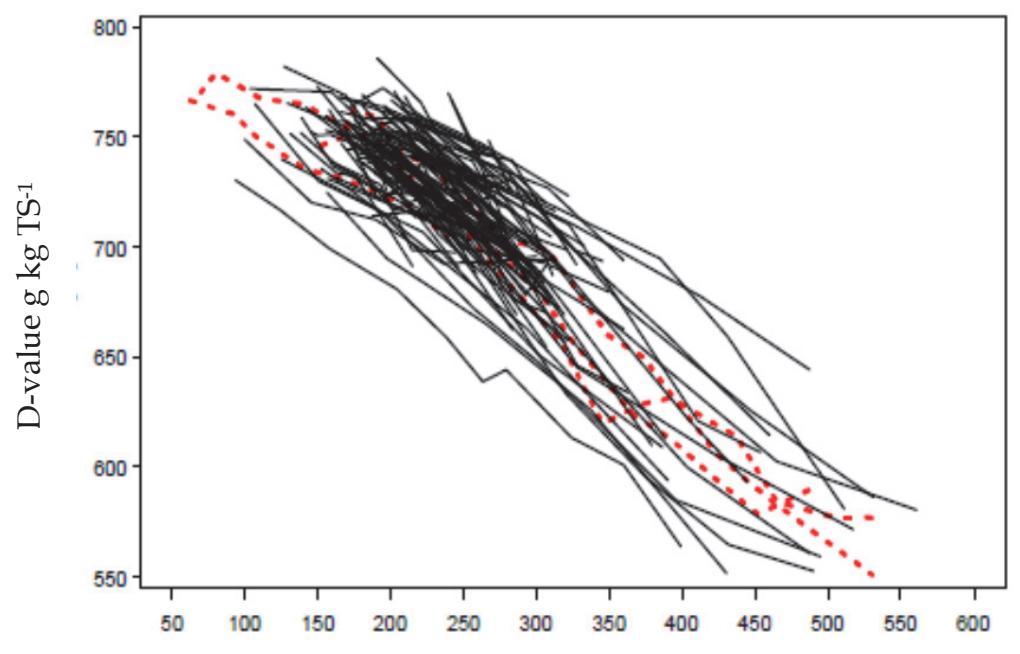

Heat summation ${ }^{\circ} \mathrm{C}$ degree days

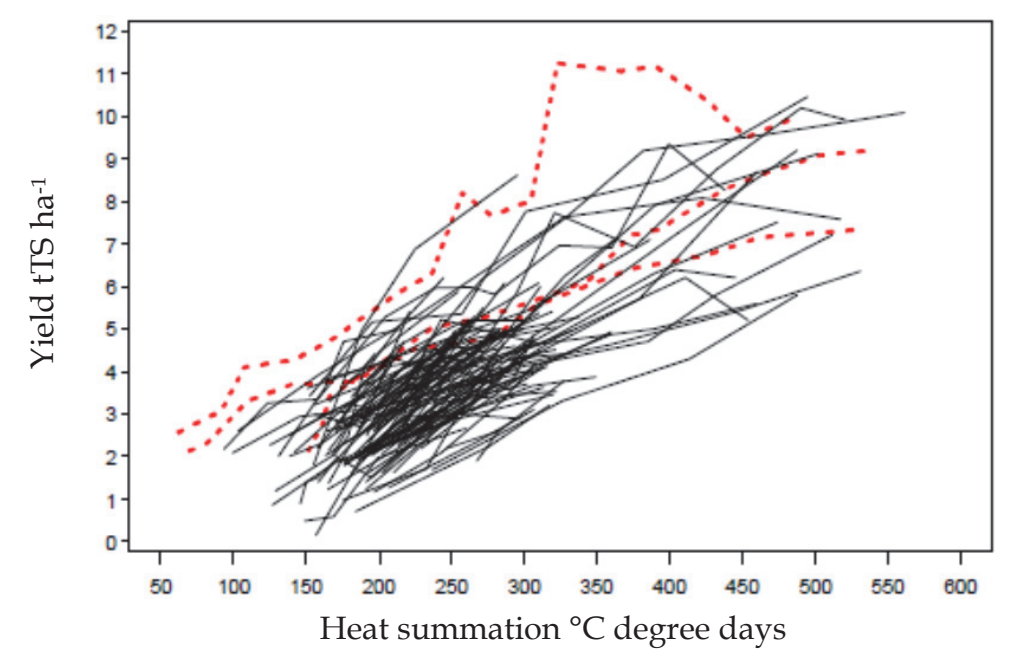

FIGURE 4 The D-value development $\left(\mathrm{g} \mathrm{kgTS}^{-1}\right)$ and the accumulation of the biomass yield (tTS ha-1) during the growing season (heat summation ${ }^{\circ} \mathrm{C}$ degree days). The broken line shows the average value from the long-term experiments in the research centre of MTT Agrifood Research Finland in Jokioinen, and the lines are the values from a one year experiment series in Finland (Rinne et al. 2010). 
Grasslands remove $\mathrm{CO}_{2}$ from the atmosphere, and the $\mathrm{C}$ accumulation in various grass species has been reported to been 2.45-4.43 tC ha-1 (Saggar et al. 1997), and the amount of $\mathrm{C}$ sequestered by grassland soil was 0.6-2 $\mathrm{tC} \mathrm{ha}^{-1} \mathrm{a}^{-1}$ (Byrne et al. 2007). In other studies, the minimum amount of $0.6 \mathrm{tC} \mathrm{ha}^{-1} \mathrm{a}^{-1}$ was reported as the potential soil carbon sequestration rate for perennial ryegrass, permanent crops and bioenergy crops under European agricultural conditions (Freibauer et al. 2004, Jones \& Donnelly 2004). Perennial grasses allocate more carbon to the root structure than annual grasses; furthermore, perennial grasslands with low input and high diversity of different species have also been reported to provide greater GHG reduction, soil and root carbon sequestration, and more usable energy than corn for bioethanol and soybeans for biodiesel (Tilman et al. 2006).

The rise in temperature, resulting from climate change, can benefit crop production by lengthening the growing season and increasing the heat summation (IPCC 2007). In the coming decades, the weather conditions and growing season in Finland may approach those currently found in Denmark (Hakala \& Peltonen-Sainio 2008). Due to the warmer growing seasons, the interest in the cultivation of higher yielding crop species has increased. Tests in the first decade of the twenty-first century have shown that maize and crop species, and varieties from Central Europe, have succeeded above the norm in warmer growing seasons in Finland (Hakala \& Peltonen-Sainio 2008).

Maize has been perceived a good energy crop for biogas process and it is the most popular feedstock for biogas plants in Germany and Austria (Amon et al 2007 a,b, Weiland 2010). The research on maize cultivation for biogas production has been concentrated in Central Europe (Amon et al 2007 a,b, Schittenhelm 2009, Bruni et al. 2010, Herrmann \& Rath 2012), because it produces the highest net energy yield per hectare when compared with other energy crops like sunflower, grass and whole crop grain silage (Comino et al. 2010, Weiland 2010). Silage maize is a key component of ruminant diets in Central Europe due to its high yield and energy content: for this reason, maize is characterized by good digestibility. The digestibility and nutritional value of the maize stover has been studied, modified and improved (Tolera et al. 1998, 1999, Kruse et al. 2008). Cell wall concentration, composition and degradability are thought to limit forage digestibility (Jensen et al. 2005) and influence anaerobic digestion. Maize is considered to be a chill-sensitive species with a relatively high temperature optimum for germination, development, and dry matter accumulation. In climates characterized by a cool and humid spring, adaptation has been partially successful due to late planting, and breeding for early-maturing maize hybrids. An improvement in tolerance for cooler conditions would support maize cultivation in boreal conditions, and nowadays, maize breeders have developed new biogas maize varieties that are tall, late maturing, and the TS yields per hectare of these are over $30 \mathrm{t} \mathrm{ha}^{-1}$ (Kreps 2010). The cultivation of the maize in boreal conditions have to be researched, because shorter growing season and longer photoperiod than Central Europe have an effect of the yields, the growth habit and the amount of plant parts.

The cultivation and use of non-food plants are certainly more sustainable options for bioenergy production than using food crops, which can also be used 
as food and for feed production. There is a need to find novel energy crops for bioenergy production, which can produce high TS yields and methane yields per hectare. These novel energy crops could be found among weeds, wild plants or fodder plants, which have not been used for bioenergy or biogas production previously. Weeds and wild plants usually need a lower fertilization input, they use nitrogen efficiently, and they can grow in poorer conditions than crops for food and feed production (Nissinen et al. 2010). Annual and perennial plants and weeds can generally be cultivated on fallow and marginal lands, which cannot be used to cultivate food or feed crops, such as fields with poor growing conditions, old peat bogs and land close to roads.

The novel energy crops for biogas production in northern conditions could be also screened among $\mathrm{C}_{4}$ plants, which grow best in the tropics and subtropics (below latitudes of $45^{\circ}$ ), have a good water use efficiency, grow in the high temperatures and produce high TS yields in warm conditions (Mahmood \& Honermeier 2012). $C_{4}$ plants cannot produce feed or food in northern conditions, because the growing season is too short. The quantity of plants and crops increases the diversity of the fields when cultivating other crops like traditional grasses, cereals, maize and sugar beets.

Gunaseelan (1997) reviewed specific methane yields from fruit and vegetables, grasses, woody biomass, terrestrial weeds, marine biomass and freshwater biomass, and he reported that weeds were a potential biomass source for bioenergy production (Gunaseelan, 1997). Subramanian and Sampathrajan (1999) studied the physical and chemical properties of 26 weed species and found promising species for biogas production in India. Many perennial and annual plants have been studied for combustion and biofuel production, including amaranth (Amaranthus L.) (Viglasky et al. 2009), common reed (Phragmites australis) (Kuhlman et al. 2012) and hemp (Cannabis sativa Linnaeus) (Prade et al. 2011). Biogas production assays were done for many crops, crop residues and weeds some years ago (Gunaseelan 1997, Subramanian \& Sampathrajan 1999, Lehtomäki et al. 2008), but laboratory scale experiments using novel energy crops for anaerobic digestion and co-digestion with manure have not been undertaken. It is important that the energy crops can produce high methane yields, and that they can be used in the biogas process.

\subsubsection{Energy balance and greenhouse gas emissions of the biogas plant using energy crops}

The energy balance of the crop based energy system is dependent on the energy consumption of the biomass cultivation, as well as the energy consumption of the process. The energy requirements of cultivation can be divided into direct and indirect energy inputs. The direct energy inputs are those which directly involve the use of fuel in the operation, for example, diesel fuel used in tractors for cultivating and harvesting energy crops. The indirect energy inputs are the energy consumed in the manufacture and delivery of the products used in the energy crop cultivation, such as fertilizers, herbicides, preservative manufacturing and machinery, and the equipment used in cultivation (Smyth et al. 2009).The opera- 
tion of the biogas plant (heating and electricity demand) generally consumes the most energy in the biogas process (from the cultivation of the feedstock to the use of biogas), corresponding to approximately $40-80 \%$ of the energy demand (Berglund \& Börjesson 2006, Smyth et al. 2009, Pöschl et al. 2010). In maize and grass cultivation, the most energy demanding process is the manufacture of the chemical fertilizer (Smyth et al. 2009, Pöschl et al. 2010). In the cultivation of energy crops for the biogas process, the digestate can be used as a fertilizer, and the high energy input of the manufacturing fertilizers can be avoided (Bachmaier et al. 2010). The energy balance of different crops varies among crop species, cultivation managements, growing conditions and climatic conditions. In previous studies for Irish conditions, the net energy yields from the cultivation of grass (67-78 GJ ha-1 $\mathrm{a}^{-1}$ ) (Smyth et al. 2009) for biogas production were higher than rapeseed biodiesel (25 GJ ha-1 a-1) (Thamsiriroj \& Murphy 2009) and wheat ethanol (4 GJ ha-1 $\mathrm{a}^{-1}$ ) (Murphy \& Power 2008).

The Renewable Energy Directive states that the GHG savings should be at least $35 \%$, as defined by using fossil fuels as a reference. From the beginning of the year 2017, the savings must be at least $50 \%$, and from 2018 at least $60 \%$ for the biofuels and bioliquids produced (European Parliament 2009). If biogas is produced from co-digesting maize and manure, the GHG savings have been 92 $\%$, when compared to fossil fuel (Boulamanti et al. 2013). The sustainability of energy crop cultivation can be increased to minimize agronomic inputs like fertilization (Fazio \& Monti 2011). Using digestate as a fertilizer, the GHG emissions decrease, because high GHG emissions occur in manufacturing nitrogen and phosphorus fertilizers (Bachmaier et al. 2010). Perennial crops have substantially higher environmental benefits than annual crops, and a significant amount of emitted $\mathrm{CO}_{2}$ can be avoided through the cultivation of perennial grasses (Fazio \& Monti 2011). 


\section{OBJECTIVES}

The main objective of this thesis was to evaluate the methane yield of grasses, maize and novel energy crops through the anaerobic digestion process in boreal conditions. The sub-objectives were:

- To determine the specific methane yields of different grass species cultivated under boreal conditions, as well as how harvesting time affects the methane yields per ha (I).

- To evaluate how the harvest time and maize variety affect the methane yield, dry matter yield per hectare and proportion of the various plant parts (stem, leaves and cobs) in boreal conditions (II).

- To investigate the methane yield from the co-digestion of maize and liquid cow manure in CSTRs, with an increasing share of maize in the feedstock. The post-methanation potential and nutrient and trace element concentration of the digestate were also determined (III).

- To determine the methane yields and TS yields per hectare of novel energy crops, and from the most promising novel energy crop, brown knapweed (Centaurea jacea L.), the effect of harvest time on the specific methane yield and its methane production in a CSTR trial with liquid cow manure (IV).

- To compare the energy balance of energy crop cultivation to the biogas production. 


\section{MATERIALS AND METHODS}

\subsection{Main experiments}

The methane production experiments of this thesis consist of both batch experiments and CSTRs. The main experiments of the thesis are summarized in Table 1.

TABLE 1 The main experiments in the thesis showing the substrates, objectives, model and volume of the system.

\begin{tabular}{|c|c|c|c|c|}
\hline Substrate & Objective & $\begin{array}{l}\text { System } \\
\text { (Volume) }\end{array}$ & Details & Paper \\
\hline $\begin{array}{l}\text { Grass } \\
\text { species }\end{array}$ & $\begin{array}{l}\text { The specific methane yield, TS yield and } \\
\text { methane yield per hectare of different } \\
\text { grass species } \\
\text { - } \quad \text { The effect of harvest time and year }\end{array}$ & Batch (1 l) & Table 2 & I \\
\hline $\begin{array}{l}\text { Maize } \\
\text { varieties }\end{array}$ & $\begin{array}{l}\text { The harvest time and variety affecting } \\
\text { the methane and TS yield per hectare } \\
\text { - The effects of stems, leaves and cobs }\end{array}$ & Batch (1 l) & Table 3 & II \\
\hline Maize & $\begin{array}{l}\text { The co-digestion with cow manure } \\
\text { - } \quad \text { High share of maize } \\
\text { - } \quad \text { Post-methanation potential } \\
\text { - } \quad \text { Trace elements of feedstock and diges }\end{array}$ & CSTR (5 l) & Table 12 & III \\
\hline $\begin{array}{l}\text { Novel } \\
\text { plants }\end{array}$ & $\begin{array}{l}\text { The specific methane yields, TS and } \\
\text { methane yield per hectare } \\
\text { - The effect of harvest time of brown kn }\end{array}$ & $\begin{array}{l}\text { Batch (1 l) } \\
\text { pweed }\end{array}$ & Table 4 & IV \\
\hline $\begin{array}{l}\text { Brown } \\
\text { knapweed }\end{array}$ & $\begin{array}{l}\text { The suitability of co-digestion with cow } \\
\text { manure }\end{array}$ & CSTR (5 l) & Table 13 & IV \\
\hline
\end{tabular}




\subsection{Substrates and inocula}

\subsubsection{Grass material (I)}

The grass material consisted of 4 grass species (Table 2). Three of these, cocksfoot (Dactylis glomerata L.), tall fescue (Festuca arundinaceae Schreb.) and reed canary grass (RCG) (Phalaris arundinaceae L.) were cultivated in Saarijärvi (N 60 23.248', E $22^{\circ} 33.226^{\prime}$, geographic coordinates in ETRS89, similar to WGS84), in Central Finland and Hahkiala ( $\mathrm{N} \mathrm{61}{ }^{\circ} 8.697^{\prime}$, E $24^{\circ} 35.262^{\prime}$ ) in southern Finland. The fourth, timothy was cultivated in Hahkiala. All of the grasses were fertilized and harvested during the growing season in both Saarijärvi and Hahkiala during years 2005-2007 (Table 2).

The yield of the grasses in Saarijärvi was determined by taking 4-7 samples from an area of $0.25 \mathrm{~m}^{2}$ and weighing them. The grass material was cut using a mowing machine. The grass materials in Hahkiala were harvested with a Haldrup 1500 plot harvester (J. Haldrup a/s, Løgstør, Denmark), which determined the yield by weighing the harvested biomass. A detailed description of the cultivation and materials are in paper I.

\subsubsection{Maize material (II, III)}

The maize cultivation trials were conducted during 2007 and 2008 at the research centre of MTT Agrifood Research Finland in Piikkiö in southern Finland (N 60 23.248', E 22 $33.226^{\prime}$ ) and on the Kalmari biogas farm in Laukaa in Central Finland ( $\mathrm{N} 62^{\circ} 19.389^{\prime}$, E $\left.25^{\circ} 52.415^{\prime}\right)$. The maize varieties had the maturity index FAO (Food and Agriculture organization) of 160-270 (Table 3). In Piikkiö, the maize varieties (Francisco, Amara, Marcello, Ronaldinio, Amadeo and Sampaio) were sown at two different times, in 2007 on the 17th (A) and 29th (B) of May, and in 2008 (maize varieties Amara, Ronaldinio, Amadeo, Valdez, XA7251 and KXA7254) at only one sowing time, on the 19th of May. The maize varieties were fertilized with $180 \mathrm{~kg}$ of N, $13.5 \mathrm{~kg}$ of $\mathrm{P}$ and $36 \mathrm{~kg}$ of $\mathrm{K}$ per hectare in 2007 and $118 \mathrm{~kg} \mathrm{~N}, 9 \mathrm{~kg}$ P and $14 \mathrm{~kg}$ K per hectare in 2008 in Piikkiö. In Laukaa, the maize varieties were cultivated in a 2 ha ( 1 ha Cerruti and 1 ha MAS09A) plot, and in a 3 ha (Revolver) plot in the years 2007 and 2008, respectively. The maize was sown on the 24th of May in 2007 and the 26th of May in 2008. The fertilization (80 $\mathrm{kg} \mathrm{N} \mathrm{ha-1)}$ ) was made from the digestate of the farm biogas plant treated cow manure and energy crops in 2007, and with digestate and chemically produced fertilizer, for a total of $80 \mathrm{~kg} \mathrm{~N} \mathrm{ha}^{-1}$ in 2008.

The maize from sowing time A was harvested twice (the 2nd of September, 108 days after sowing, DAS, and 22nd of October, 159 DAS) and the maize from sowing time B was harvested only once (the 2nd of September, 96 DAS) in Piikkiö in 2007 (Table 3). The maize was harvested on the 30th of August (98 DAS) in 2007 and the 25th of August (91 DAS) in 2008 in Laukaa. In 2008, the maize was harvested only once (the 1st of September, 93 DAS) in Piikkiö, because of early frost damage. During each harvest time, a total of 10 maize plants (from 
all replicates) were harvested and weighed to determine the yield. The maize was harvested at a $10 \mathrm{~cm}$ stubble height. In 2007, the different plant parts were taken separately from all maize plants of the Francisco, Amara, Marcello, Cerruti and MAS09 maize varieties. The stem (including leaf sheets and panicle), leaves (only leave blades), and cob (including the husk of the cob) were weighed. The maize variety Valdez (harvested in 2008), (middle late ripening, FAO 290) was used for the CSTR experiments (III).

TABLE 2 Cultivation site, harvest time, codes (referred to in the text), fertilization of grass species and determined TS and VS content \% of the wet weight (WW) in the grass species in this study (I).

\begin{tabular}{|c|c|c|c|c|c|c|}
\hline Grass species & $\begin{array}{l}\text { Cultivation } \\
\text { site }\end{array}$ & $\begin{array}{l}\text { Harvest } \\
\text { time }\end{array}$ & Code & $\begin{array}{l}\text { Fertilization } \\
\text { kg N-P-K ha-1 }\end{array}$ & $\begin{array}{c}\text { TS } \\
\% \\
\text { WW } \\
\end{array}$ & $\begin{array}{c}\text { VS } \\
\% \\
\text { WW } \\
\end{array}$ \\
\hline Cocksfoot & Saarijärvi & 12.9 .2005 & CF SA 05 & $27-5-8^{a}$ & 18.9 & 16.5 \\
\hline Cocksfoot & Saarijärvi & 21.6.2006 & CF SA 06 & $60-0-45$ & 39.0 & 34.6 \\
\hline Cocksfoot & Hahkiala & 17.7.2006 & CF HA $062^{\text {nd }}$ & $88-12-32$ & 33.0 & 29.6 \\
\hline Cocksfoot & Hahkiala & 13.9.2006 & CF HA $063^{\text {rd }}$ & $88-12-32$ & 22.4 & 18.2 \\
\hline Cocksfoot & Saarijärvi & 20.6.2007 & CF SA $071^{\text {st }}$ & $52-8-13$ & 23.3 & 21.0 \\
\hline Cocksfoot & Saarijärvi & 20.8.2007 & CF SA $072^{\text {nd }}$ & $60-0-45$ & 17.4 & 15.9 \\
\hline Tall fescue & Saarijärvi & 12.9.2005 & TF SA 05 & $27-5-8^{a}$ & 21.9 & 19.6 \\
\hline Tall fescue & Saarijärvi & 21.6.2006 & TF SA 06 & $60-0-45$ & 43.7 & 39.2 \\
\hline Tall fescue & Hahkiala & 17.7.2006 & TF HA $062^{\text {nd }}$ & $88-12$ & 32.6 & 29.5 \\
\hline Tall fescue & Hahkiala & 13.9.2006 & TF HA $063^{\text {rd }}$ & $88-12-32$ & 24.1 & 21.7 \\
\hline Tall fescue & Saarijärvi & 20.6.2007 & TF SA $071^{\text {st }}$ & $52-8-13$ & 22.7 & 20.7 \\
\hline Tall fescue & Saarijärvi & 20.8.2007 & TF SA $072^{\text {nd }}$ & $60-0-45$ & 17.4 & 15.9 \\
\hline Timothy & Hahkiala & 13.6.2006 & TIM HA $061^{\text {st }}$ & $110-15-40$ & 22.5 & 20.9 \\
\hline Timothy & Hahkiala & 2.8 .2006 & TIM HA $062^{\text {nd }}$ & $88-12-32$ & 36.5 & 34.0 \\
\hline Timothy & Hahkiala & 17.7.2006 & TIM HA3 $062^{\text {nd }}$ & $88-12-32$ & 35.4 & 32.8 \\
\hline Timothy & Hahkiala & 13.9.2006 & TIM HA3 $063^{\text {rd }}$ & $88-12-32$ & 19.5 & 17.8 \\
\hline RCG & Saarijärvi & 22.6.2005 & RCG SA $051^{\text {st }}$ & $27-5-8^{a}$ & 21.5 & 19.8 \\
\hline RCG & Saarijärvi & 19.8.2005 & RCG SA $052^{\text {nd }}$ & - & 22.6 & 20.4 \\
\hline RCG & Saarijärvi & 21.6.2006 & RCG SA 06 a & $60-0-45$ & 40.8 & 36.6 \\
\hline RCG & Saarijärvi & 10.7 .2006 & RCG SA 06 b & $56-0-42$ & 26.8 & 24.7 \\
\hline RCG & Saarijärvi & 20.6.2007 & RCG SA $071^{\text {st }}$ & $52-8-13$ & 25.3 & 22.0 \\
\hline RCG & Saarijärvi & 20.8.2007 & RCG SA $072^{\text {nd }}$ & $60-0-45$ & 20.0 & 18.6 \\
\hline RCG & Hahkiala & 24.9.2007 & RCG HA 07 & $80-12-32$ & 40.4 & 33.0 \\
\hline
\end{tabular}

aAlso liquid cow manure fertilization $24 \mathrm{~kg} \mathrm{~N} \mathrm{ha}^{-1}$ and $18 \mathrm{~kg} \mathrm{P} \mathrm{ha}^{-1}$. 
TABLE 3 The maturity index, sowing, harvesting and growing time, heat summation, precipitation and TS and VS contents of the maize varieties used (II).

\begin{tabular}{lcccccccc}
\hline \hline $\begin{array}{l}\text { Maize } \\
\text { variety }\end{array}$ & $\begin{array}{c}\text { Maturity } \\
\text { index }\end{array}$ & $\begin{array}{c}\text { Sowing/ } \\
\text { harvest } \\
\text { time }\end{array}$ & $\begin{array}{c}\text { Growing } \\
\text { time }\end{array}$ & $\begin{array}{c}\text { Heat } \\
\text { summation }\end{array}$ & Precipitation & TS & VS & VS/TS \\
days & $\begin{array}{c}{ }^{\circ} \text { C degree } \\
\text { days }\end{array}$ & $\mathrm{mm}^{\mathrm{b}}$ & $\%$ & $\%$ & $\%$ \\
\hline
\end{tabular}

Maize varieties in Laukaa in 2007

$\begin{array}{llllllll}\text { Cerruti } & 210 & 98 & 986 & 315 & 17.1 & 16.3 & 95 \\ \text { MAS09A } & 160 & 98 & 986 & 315 & 15.8 & 14.6 & 92\end{array}$

Maize varieties in Piikkiö in 2007

$\begin{array}{lcccccccc}\text { Francisco } & 270 & \text { A1 } & 108 & 1181 & 292 & 18.6 & 17.5 & 94 \\ \text { Francisco } & & \text { A2 } & 158 & 1419 & 370 & 27.8 & 26.0 & 94 \\ \text { Francisco } & & \text { B } & 96 & 1085 & 281 & 20.1 & 18.8 & 94 \\ \text { Amara } & 260 & \text { A1 } & 108 & 1181 & 292 & 21.2 & 19.9 & 94 \\ \text { Amara } & & \text { A2 } & 158 & 1419 & 370 & 28.0 & 26.6 & 95 \\ \text { Amara } & & \text { B } & 96 & 1085 & 281 & 19.9 & 18.7 & 94 \\ \text { Marcello } & 260 & \text { A1 } & 108 & 1181 & 292 & 19.5 & 18.4 & 94 \\ \text { Marcello } & & \text { A2 } & 158 & 1419 & 370 & 28.3 & 26.3 & 93 \\ \text { Marcello } & & \text { B } & 96 & 1085 & 281 & 18.7 & 17.7 & 95 \\ \text { Ronaldinio } & 240 & \text { A1 } & 108 & 1181 & 292 & 20.7 & 19.7 & 95 \\ \text { Ronaldinio } & & \text { B } & 96 & 1085 & 281 & 21.3 & 20.2 & 95 \\ \text { Amadeo } & 220 & \text { A1 } & 108 & 1181 & 292 & 22.2 & 21.4 & 96 \\ \text { Amadeo } & & \text { B } & 96 & 1085 & 281 & 21.5 & 20.5 & 95 \\ \text { Sampaio } & 230 & \text { A1 } & 108 & 1181 & 292 & 24.2 & 23.2 & 96 \\ \text { Sampaio } & & \text { B } & 96 & 1085 & 281 & 20.3 & 19.2 & 95\end{array}$

Maize varieties in Piikkiö in 2008

\begin{tabular}{|c|c|c|c|c|c|}
\hline Amara & 260 & 105 & 1045 & 339 & 17.6 \\
\hline Ronaldinio & 240 & & & & 16.8 \\
\hline Amadeo & 220 & & & & 15.7 \\
\hline Valdez & 290 & & & & 16.4 \\
\hline XA 7251 & $>300$ & & & & 15.7 \\
\hline KXA 7254 & $>300$ & & & & 15.6 \\
\hline
\end{tabular}

Maize variety in Laukaa in 2008

\begin{tabular}{lllllll} 
Revolver $\quad 160$ & 91 & 769 & 344 & 13.6 & 12.5 & 92 \\
\hline \hline a A sowing time 17.5.2007 & & & &
\end{tabular}

B sowing time 29.5.2007

1 harvest time 2.9.2007

2 harvest time 22.10.2007

b In Finland the heat summation is calculated the temperature over 5 degree Celsius.

c Includes the irrigation in Piikkiö. 


\subsubsection{Novel energy crops (IV)}

Nine different plants, including wild plant, weed, tall annuals (3) and perennials (4), were cultivated at the research centre of MTT Agrifood Research Finland in Piikkiö (N 60 23.248', E $22^{\circ} 33.226^{\prime}$ ) during years 2007-2010. The sowing and harvest time, and fertilization rate, are presented in Table 4 . The Jerusalem artichoke (Helianthus tuberosuVL.) (no tubes) and sunflower (Helianthus annuus L.) were harvested in September in 2007. Brown knapweed was harvested at two different harvest times in June (A07) and August (B07) in 2007. However, in 2008 brown knapweed was harvested four times (A-D08) (Table 4) to measure the optimal harvest time for biogas production. Brown knapweed was harvested about $15 \mathrm{~cm}$ above the ground, and a rosette of leaves was left to grow and produce the yield again. Sorghum (Sorghum Sudanese Stapf.) ( $\mathrm{C}_{4}$ plant) and Japanese millet (EchinochlRa crusgalli L.) ( $C_{4}$ plant) were harvested only once in September 2008 (Table 4). In 2010, giant knotweed (Fallopia sachalinensis F. Schmidt), giant goldenrod (Solidago gigantean Aiton), hemp-agrimony (Eupatorium cannabinum L.) and amaranth (Amaranthus cruentus var. Oeschberg L.) ( $\mathrm{C}_{4}$ plant) were cultivated, and harvesting was done in August. The experimental plots of the plants were harvested at a $10 \mathrm{~cm}$ height, and collected by mowing machinery (Haldrup). The harvest plot was $1.375 \mathrm{~m} \times 7 \mathrm{~m}$. The fresh weight of the plant material was weighed (True test). Detailed descriptions of the materials are in the original paper IV.

TABLE 4 The sowing and harvest times, fertilization, TS and VS content of potential novel energy crops for biogas production (IV).

\begin{tabular}{|c|c|c|c|c|c|c|c|c|}
\hline Novel energy crop & & $\begin{array}{l}\text { Ann./ } \\
\text { Peren. }\end{array}$ & $\begin{array}{c}\text { Sowing } \\
\text { time }\end{array}$ & $\begin{array}{c}\text { Harvest } \\
\text { time }\end{array}$ & $\begin{array}{c}\text { Fertilization } \\
\text { N-P-K } \\
\text { kg ha-1 }\end{array}$ & $\begin{array}{c}\text { TS } \\
\% \\
\text { WW }\end{array}$ & $\begin{array}{c}\mathrm{VS} \\
\% \\
\mathrm{WW}\end{array}$ & $\begin{array}{c}\mathrm{VS} / \mathrm{TS} \\
\%\end{array}$ \\
\hline Jerusalem artichoke & & Peren. & 2007 & 2.9 .2007 & $7-2-8$ & 33.1 & 29.7 & 0.90 \\
\hline Sunflower & & Ann. & 2007 & 2.9.2007 & $21-7-27$ & 14.7 & 13.0 & 0.88 \\
\hline \multirow[t]{6}{*}{ Brown knapweed } & A07a & Peren. & 2006 & 14.6.2007 & $30-2-4$ & 17.7 & 16.0 & 0.90 \\
\hline & B07 & & 2006 & 14.8.2007 & $30-2-4$ & 34.3 & 31.8 & 0.93 \\
\hline & A08 & & 7.6.2007 & 16.6.2008 & $30-2-4$ & 18.1 & 16.2 & 0.90 \\
\hline & B08 & & 7.6.2007 & 7.7.2008 & $30-2-4$ & 23.8 & 21.8 & 0.91 \\
\hline & $\mathrm{C} 08$ & & 7.6.2007 & 5.8 .2008 & $30-2-4$ & 30.0 & 27.6 & 0.92 \\
\hline & D08 & & 7.6.2007 & 1.9 .2008 & $30-2-4$ & 42.9 & 39.4 & 0.92 \\
\hline Sorghum & & Ann. & 26.5.2008 & 1.9 .2008 & $120-9-14$ & 15.0 & 13.6 & 0.90 \\
\hline Japanese millet & & Ann. & 26.5.2008 & 1.9 .2008 & $120-9-14$ & 17.4 & 15.1 & 0.87 \\
\hline Giant knotweed & & Peren. & 2008 & 24.8.2010 & $60-5-7$ & 30.8 & 28.1 & 0.91 \\
\hline Giant goldenrod & & Peren. & 2007 & 24.8.2010 & $60-5-7$ & 39.0 & 36.6 & 0.94 \\
\hline Hemp-agrimony & & Peren. & 2008 & 24.8.2010 & $60-5-7$ & 27.2 & 24.7 & 0.91 \\
\hline Amaranth & & Peren. & 2010 & 24.8.2010 & $60-5-7$ & 18.0 & 14.4 & 0.80 \\
\hline
\end{tabular}

aA, B, C, D are different harvest times in year 2007 and 2008.

Ann. $=$ Annual

Peren. $=$ Perennial 


\subsubsection{Handling of crop materials}

After harvesting, the grass material was taken to the laboratory and chopped into particles of ca. $1 \mathrm{~cm}$ with scissors (grasses in Saarijärvi) and stored at $4{ }^{\circ} \mathrm{C}$ in a nitrogen atmosphere until used in the methane potential assays and analysis (I). The grass materials from Hahkiala (I) were also chopped into particles of ca. $1 \mathrm{~cm}$ and oven-dried $\left(60^{\circ} \mathrm{C}, 24 \mathrm{~h}\right)$ after each harvest. The methane potential assays of the grass samples from Hahkiala were performed using oven-dried material.

After harvesting, the maize and novel energy crop materials were cut using a chopper (SD 180 E, Wolf Garten, Germany), and then cut with scissors to a ca. 1 $\mathrm{cm}$ particle size in the laboratory, and stored at $4{ }^{\circ} \mathrm{C}$ in a nitrogen atmosphere until used in the methane potential assays and analysis (II-IV). The maize (variety Valdez; III) and brown knapweed (harvested 7.7.2008; IV) from the CSTR trials was frozen and stored at $-20^{\circ} \mathrm{C}$ in plastic bags in portions equivalent to three to four days' worth of feedstock. After thawing, the particles were further reduced using scissors to a particle size of about $0.5 \mathrm{~cm}$ to assist the syringe feeding. The feed mixtures for the reactor studies were prepared daily.

\subsubsection{Liquid cow manure and inocula}

The inocula used to inoculate the methane potential assays (I-IV) and reactor experiments (III, IV) was obtained from a mesophilic farm digester (in Laukaa) processing liquid cow manure, energy crops and industrial by-products from a candy factory (Table 5). The liquid cow manure for the CSTR trials was obtained from a dairy farm in central Finland (in Laukaa) (Table 6).

TABLE 5 Characteristics of the inocula used in the batch and CSTR experiments (average values).

\begin{tabular}{lccccc}
\hline \hline Paper & $\begin{array}{c}\text { TS } \\
\% \text { WW }\end{array}$ & $\begin{array}{c}\text { VS } \\
\% \text { WW }\end{array}$ & $\begin{array}{c}\mathrm{N}_{\text {tot }} \\
\mathrm{g} \mathrm{l}^{-1}\end{array}$ & $\begin{array}{c}\mathrm{NH}_{4}-\mathrm{N} \\
\mathrm{g} \mathrm{l}^{-1}\end{array}$ & $\begin{array}{c}\text { SCOD } \\
\mathrm{g} \mathrm{l}^{-1}\end{array}$ \\
\hline $\mathrm{I}$ & 6.1 & 4.8 & 3.2 & 1.1 & 11.0 \\
II & 5.7 & 4.7 & 2.3 & 0.7 & 13.0 \\
III & 5.0 & 3.9 & 2.5 & n.a. & 12.0 \\
IV & 5.4 & 4.3 & 2.4 & 0.7 & 12.5 \\
\hline \hline
\end{tabular}

n.a. not analysed 
TABLE 6 The characteristics of the inocula, liquid cow manure, maize (Valdes variety) and brown knapweed in the CSTR trials (III, IV). Specific methane yields are given as the mean \pm standard deviation (SD).

\begin{tabular}{|c|c|c|c|c|c|c|c|c|}
\hline \multirow[t]{2}{*}{ Substrate } & TS & VS & $\mathrm{N}_{\text {tot }}$ & $\mathrm{NH}_{4}-\mathrm{N}$ & SCOD & \multicolumn{3}{|c|}{ Specific methane yield } \\
\hline & WW & WW & $\mathrm{g} \mathrm{l}^{-1}$ & $\mathrm{~g} \mathrm{l}^{-1}$ & $\mathrm{~g} \mathrm{l}^{-1}$ & $1 \mathrm{kgVS}^{-1}$ & $1 \mathrm{kgTS}^{-1}$ & $1 \mathrm{kgWW}^{-1}$ \\
\hline Inoculum & 5.0 & 3.9 & 2.5 & n.a. & 12.0 & 81 & 104 & 4 \\
\hline Maize $^{\mathrm{a}}$ & 16.4 & 15.2 & $15^{\mathrm{b}}$ & $0.15^{\mathrm{b}}$ & $134^{b}$ & $360 \pm 8$ & $334 \pm 7$ & $55 \pm 1$ \\
\hline Brown knapweed ${ }^{a}$ & 23.8 & 21.8 & 11.2 & $0.27 \mathrm{~b}$ & $177.1^{b}$ & $329 \pm 41$ & 301 & 72 \\
\hline Manure Ia & 5.7 & 4.7 & 2.3 & 0.76 & 13.1 & $212 \pm 18$ & $172 \pm 16$ & $10 \pm 2$ \\
\hline Manure II & 5.0 & 4.3 & 1.5 & 0.45 & 8.6 & n.a. & n.a. & n.a. \\
\hline
\end{tabular}

Cow manure I was used in feedstock during days 1-66, and cow manure II during days 67-136.

aMethane production of inoculum subtracted.

${ }^{\mathrm{b}} \mathrm{mg}$ gTS $^{-1}$

n.a. not analysed

\subsection{Experimental set up}

\subsubsection{Methane potential assays (I-IV)}

The methane potential assays were performed as triplicate experiments in 11 glass bottles at $35 \pm 1{ }^{\circ} \mathrm{C}$, where $250-350 \mathrm{ml}$ of the inoculum was added to each bottle, followed by the addition of the substrate at a $\mathrm{VS}_{\text {substrate }} / \mathrm{VS}_{\text {inoculum }}$ ratio of 1. Bottles with inoculum only were incubated as the controls. All bottles were filled to a liquid volume of $750 \mathrm{ml}$ with distilled or tap water, and $4 \mathrm{~g} \mathrm{l}^{-1}$ sodium bicarbonate $\left(\mathrm{NaHCO}_{3}\right)$ was added as a buffer. The contents of the bottles were flushed with $\mathrm{N}_{2}$-gas for $3 \mathrm{~min}$ before closing to remove residual oxygen. The bottles were sealed with butyl rubber stoppers, and gas collection tubing was made from a PVC-based material with plasticizer (Masterflex Tygon ${ }^{\circledR}$ fuel \& lubricant). The produced gas was collected in aluminium gas bags, and the methane content and gas production were measured two to three times a week. The contents of the bottles were manually mixed before each gas measurement. Assays with inoculum only were carried out to subtract the methane potential of the inoculum from that of the substrates. The gas production of the bottles was monitored for 60-120 days.

\subsubsection{Co-digestion experiments (III, IV)}

The reactor experiments were carried out in three parallel CSTRs. The reactors (referred to as R1, R2 and R3) were constructed of glass, each with a total volume of 51 and a liquid volume of 4 , stirred continuously at $300 \mathrm{rpm}$ (Heidolph MR 
3000 , Germany) and incubated at $35 \pm 1{ }^{\circ} \mathrm{C}$. The reactors were inoculated on day 0 with 41 of inoculums, and when the methane concentration of the produced biogas rose to $50 \%$, the addition of the feedstock was begun. The feedstocks were cow manure (R1), brown knapweed and cow manure (R1), and maize and cow manure in different shares and OLR (R2 and R3) (Table 6). The reactors were fed with a syringe once a day, 5 days per week, and the equivalent volume of the digestate was removed from the reactor. In reactor R3, the liquid fraction of the digestate was recirculated back to the reactor along with the daily feed, so that the HRT would be long enough. The liquid fraction was obtained by centrifuging (for $10 \mathrm{~min}$, at $350 \mathrm{rpm}$ ) the removed digestate. The biogas was collected in aluminium gas bags via silicone tubes, and the gas in the tubes was sampled through glass septa. The applied feedstock mixtures were prepared daily.

\subsubsection{Post-methanation assays (III, IV)}

The post-methanation potentials of the digestates in the co-digestion experiments with cow manure and maize, or brown knapweed, were measured in batch experiments in triplicate $120 \mathrm{ml}$ serum vials incubated at $35 \pm 1{ }^{\circ} \mathrm{C}$. The digestate $(40 \mathrm{~g})$ was added to the vials which were then sealed with butyl rubber stoppers and aluminium crimps. The contents of the vials were flushed with $\mathrm{N}_{2}$ gas for $3 \mathrm{~min}$ to remove residual oxygen. The post-methanation assays were incubated for a total of 125-136 days.

\subsection{Analyses and calculations}

TS and VS were analysed according to Finnish standard methods SFS 3008 (Finnish Standard Association 1990), and the $\mathrm{pH}$ was measured with a Metrohm $774 \mathrm{pH}$-meter (Metrohm, Switzerland). The soluble chemical oxygen demand (SCOD) was analysed according to SFS 5504 (Finnish Standard Association 2002a). Ammonium nitrogen $\left(\mathrm{NH}_{4}-\mathrm{N}\right)$ and total nitrogen $\left(\mathrm{N}_{\text {tot }}\right)$ were determined according to the Tecator application note (Perstorp Analytical Tecator 1995) with a Kjeltec system 1002 distilling unit (Tecator). The energy crop samples for $\mathrm{NH}_{4}-\mathrm{N}$ and SCOD were extracted according to SFS-EN 12457-4 (Finnish Standard Association 2002b) and were filtered with GF 50 glass-fibre filter papers (Schleicer \& Schuell). The detailed descriptions of the analyses are in the articles I-IV.

The digestate and feedstock samples for the trace element analysis (III) were first dried $\left(24 \mathrm{~h}, 105^{\circ} \mathrm{C}\right)$, milled in a rotor mill (Pulverisette 14, Fritsch, Germany) and stored at $22{ }^{\circ} \mathrm{C}$ until analysed. The concentration of the trace elements was measured using a Perkin-Elmer (Norwalk, CT, USA) Optima 4300 DV ICP-OES using the following default parameters of the instrument: nebulizer flow 0.5-1.0 1 min $^{-1}$, auxiliary gas flow $0.21 \mathrm{~min}^{-1}$, plasma gas flow $151 \mathrm{~min}^{-1}$ and plasma power of 1300 or $1400 \mathrm{~W}$ (Väisänen et al. 2008). 
The volatile fatty acid (VFA) (III, IV) content was analysed with a gas chromatograph equipped with a flame-ionization detector (Perkin Elmer Autosystem XL GC, HP-INNOWax-column, $30 \mathrm{~m} \times 0.32 \mathrm{~mm} \times 25 \mu \mathrm{m})$. The operating conditions were: oven temperature $100-160{ }^{\circ} \mathrm{C}\left(25^{\circ} \mathrm{C} \mathrm{min}-1\right)$, and injection port and detector $225^{\circ} \mathrm{C}$. Helium was used as the carrier gas.

Gas samples (I-IV) were taken through stoppers from the gas phase with a pressure-locked glass syringe (Supelco, Pressure-Lok® Series A-2 Syringe, Bellefonte, USA). The methane content of the biogas was measured using a gas chromatograph (Perkin Elmer Arnel Clarus 500, Alumina column $30 \mathrm{~m} \times 0.53$ $\mathrm{mm})$ with a flame-ionisation detector. The operating temperature conditions were: oven $100{ }^{\circ} \mathrm{C}$, detector $225^{\circ} \mathrm{C}$, and injection port $250{ }^{\circ} \mathrm{C}$. Argon was used as a carrier gas $\left(14 \mathrm{ml} \mathrm{min}{ }^{-1}\right)$. The volume of the produced biogas was measured by water displacement.

The specific methane yields were calculated as $1 \mathrm{kgVS}^{-1}, 1 \mathrm{kgTS}^{-1}$ and $1 \mathrm{~kg}$ $W^{-1}$, with the $\mathrm{CH}_{4}$ production of the inoculum subtracted. The methane yields of the post-methanation potential $\left(1 \mathrm{kgVS}_{\mathrm{feed}^{-1}}, 1 \mathrm{kgTS}_{\mathrm{feed}}{ }^{-1}, 1 \mathrm{kgWW}^{-1}\right)$ assays were calculated per VS and TS, per feed of the CSTR reactor. Potential methane yields and energy yields (MWh $\mathrm{CH}_{4}, 1 \mathrm{~m}^{3} \mathrm{CH}_{4}$ corresponds to $10 \mathrm{kWh}$ ) (Lide \& Frederikse 1996) per hectare were calculated using the TS yield per hectare and the specific methane yield of each crop (I, II, IV). All methane yields were converted to normal conditions: $273 \mathrm{~K}$ and $101.3 \mathrm{kPa}$.

The statistical analysis of the results from the specific methane yields (I, II), TS yields per hectare (I, II), methane yields per hectare (II) and maize characteristic (II) were done using the statistical program SPSS version 16.0 for Windows (SPSS 2008), and from the specific methane yield and characteristics of the novel energy crops (IV) and the Pearson's correlation coefficient for the methane yields per hectare of grasses were done using the statistical program IBM SPSS statistic 19 (SPSS 2010). First, the normality of the variable values was checked with Shapiro-Wilk normality test, next the analysis of variance (ANOVA) or t-test was carried out, and then a Bonferroni test was employed for testing the statistical significance of the mean differences, if needed. The Pearson's correlation analysis was used to evaluate the dependence of methane yields per hectare and specific methane yields or TS yields per hectare of grasses. The significance of the mean differences was measured at the probability level of $5 \%(p=0.05)$.

The HRT and OLR in the reactor (III, IV) experiments were calculated for five feeding days per week; however, for practical (weekly) values, the two unfed days during the weekends should be considered. Values for the gas production and digestate characteristics are presented as averages over the final two weeks of the feeding period. 


\subsection{Energy balance of cultivation energy crops for biogas production}

The energy balance (input/output ratio) of the cultivation of grass, maize and brown knapweed for biogas production was calculated under boreal conditions. The energy balances are considered to be the primary energy of the cultivation inputs (fertilization, herbicides, lime, preservative and seed) and the consumption of the primary energy (diesel) used for cultivation management and harvesting (Table 7). The heat and electricity consumption of the biogas plant have not been considered, nor have the manufacturing or repair of the machines and buildings. The energy balances are calculated for two different fertilization strategies: one is for the chemical fertilizers used (Y3 NPK 20-3-8, Kemira GrowHow, Helsinki), and the other is for the digestate for the biogas plant for fertilization. The digestate was assumed to contain the nutrient average concentration of the CSTR experiments $\left(\mathrm{N}_{\text {tot }} 2.2 \mathrm{~kg} \mathrm{t}^{-1}, \mathrm{P} 0.42 \mathrm{~kg} \mathrm{t}^{-1}\right.$ and $\mathrm{K} 3.36 \mathrm{~kg}$ $\left.\mathrm{t}^{-1}\right)$ (III, IV).

The grass is cultivated on a five year cropping system, and it was sown (25 $\mathrm{kg} \mathrm{ha}^{-1}$ ) under grain, which is a typical way to establish grassland in Finland. The grain yield was used for food or feed, but the sowing and ploughing methods are allocated for grass cultivation. The TS yield of the grass was $7.4 \mathrm{tTS} \mathrm{ha}^{-1}$ (TS $26 \%$ WW and VS $23 \%$ WW) (I) and the specific methane yield of the grass was 3001 $\mathrm{kgTS}^{-1}(\mathrm{I})$. The grass was harvested two times per growing season (Table 7). In the spring, and after the first harvesting, it was fertilized with either chemical fertilizer or digestate from the biogas plant (total $170 \mathrm{~kg} \mathrm{~N} \mathrm{ha}^{-1}$ ) according to the nitrate directive (Finlex 2000) and limits of agri-environmental regulation (MAVI 2009). After the fifth harvest year, the grass will be spread with glyphosate (1400 $\mathrm{g} \mathrm{ha}^{-1}$ ) before ploughing.

Maize is an annual crop, and it was sown $\left(20 \mathrm{~kg} \mathrm{ha}^{-1}\right)$ every year. The TS yield per hectare was $12 \mathrm{tTS} \mathrm{ha}^{-1}$ (TS \% 20 and VS \% 18.5), and the specific methane yield was $3251 \mathrm{kgTS}^{-1}$ (II). The maize was harvested once at the end of the growing season in late August. The herbicides $\left(1000 \mathrm{~g} \mathrm{ha}^{-1}\right)$ were spread once during the growing season, and the ploughing and sowing must be done every year (Table 7). Maize was fertilized at a total of $90 \mathrm{~kg} \mathrm{~N} \mathrm{ha}^{-1}$, according to the limits of agri-environmental regulation (MAVI 2009), with either chemical fertilizer or digestate from the biogas plant.

Brown knapweed is a wild plant and a novel energy crop for biogas production. It can be cultivated several years in the same field, and was cultivated in an 8 year crop rotation (Table 7). It was sown (20 kg ha-1) in spring and harvested once in the growing season in August. The TS yield per hectare

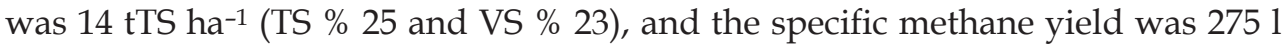
kgTS$^{-1}$ (IV). The brown knapweed field was spread three times during the eight year crop rotation with herbicides $\left(1000 \mathrm{~g} \mathrm{ha}^{-1}\right)$. The fertilization rate of brown knapweed was $50 \mathrm{~kg} \mathrm{~N} \mathrm{ha}^{-1}$, using either chemical fertilizer or digestate from the biogas plant. 
TABLE 7 Diesel $\left(\mathrm{l} \mathrm{ha}^{-1}\right)$ and energy consumption of cultivation management (MJ ha-1 $\mathrm{a}^{-1}$ ) and number of times the cultivation management must be done per year $\left(\mathrm{a}^{-1}\right)$ for grass, maize and brown knapweed.

\begin{tabular}{|c|c|c|c|c|c|c|c|c|}
\hline \multirow[t]{2}{*}{ Operation } & \multirow[b]{2}{*}{$1 \mathrm{ha}^{-1}$} & \multicolumn{2}{|c|}{ Grass } & \multicolumn{2}{|c|}{ Maize } & \multicolumn{2}{|c|}{$\begin{array}{c}\text { Brown } \\
\text { knapweed }\end{array}$} & \multirow[t]{2}{*}{ Ref. } \\
\hline & & $a^{-1}$ & $\begin{array}{c}\text { MJ } \\
\text { ha }^{-1} \mathrm{a}^{-1}\end{array}$ & $a^{-1}$ & $\begin{array}{c}\text { MJ } \\
\text { ha }^{-1} a^{-1}\end{array}$ & & 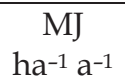 & \\
\hline Ploughing & 24 & 0.2 & 199 & 1.0 & 994 & 0.13 & 124 & $\mathrm{a}, \mathrm{b}, \mathrm{c}, \mathrm{d}, \mathrm{e}$ \\
\hline Harrowing (levelling) & 5 & 0.2 & 41 & 1.0 & 207 & 0.13 & 26 & $a, b, c$ \\
\hline Harrowing, $3.8 \mathrm{~m}$ & 5.5 & 0.2 & 46 & 1.0 & 228 & 0.13 & 28 & $\mathrm{a}, \mathrm{c}, \mathrm{d}, \mathrm{e}, \mathrm{f}$ \\
\hline Sowing, $2.5 \mathrm{~m}$ & 3.7 & 0.2 & 31 & - & 0 & 0.13 & 19 & $\mathrm{a}, \mathrm{b}, \mathrm{c}, \mathrm{d}, \mathrm{e}$ \\
\hline Sowing maize & 7 & - & - & 1.0 & 290 & - & - & $\mathrm{b}$ \\
\hline Rolling & 2 & - & - & 1.0 & 83 & 0.13 & 10 & $a, b, d, e$ \\
\hline Liming & 2.5 & 0.2 & 21 & 0.2 & 21 & 0.13 & 13 & $\mathrm{~d}$ \\
\hline Spreading glyphosate & 1.8 & 0.2 & 15 & - & - & 0.13 & 9 & $\mathrm{a}, \mathrm{e}$ \\
\hline Spreading herbicide & 1.5 & 0.2 & 12 & 1.0 & 62 & 0.25 & 16 & $\mathrm{~b}, \mathrm{c}, \mathrm{d}$ \\
\hline Fertilization chemical & 4.8 & 2.0 & 397 & 1.0 & 199 & 1.0 & 199 & $\mathrm{e}$ \\
\hline Fertilization digestate & 7.2 & 2.0 & 596 & 2.0 & 596 & 1.0 & 298 & $\mathrm{~b}$ \\
\hline Cutting & 6 & 2.0 & 497 & 1.0 & 248 & 1.0 & 248 & $\mathrm{a}, \mathrm{c}, \mathrm{e}$ \\
\hline Forage harvesting & 12 & 2.0 & 994 & 1.0 & 497 & 1.0 & 497 & $a, f, g$ \\
\hline
\end{tabular}

Ref. = References

a: Dalgaard et al. (2001)

b: Kelm et al. (2004)

c: Mikkola \& Ahokas (2009)

d: Mäkinen et al. (2006)

e: Palonen \& Oksanen (1993)

f: Smyth et al. (2009)

g: Gerin et al. (2008)

- The cultivation management has not been done to the crop.

The production and distribution of diesel fuel was estimated to represent $16 \%$ of the energy content in the fuel, and therefore $41.4 \mathrm{MJ}$ of primary energy per litre (Edwards et al. 2003). The biomass from the fields is cut, forage harvested and the preservative $\left(2.51 \mathrm{tWW}^{-1}\right)$ added to the harvested biomass. Producing preservatives consumes $3.68 \mathrm{GJ} \mathrm{t}^{-1}$ of primary energy (Grönroos \& Voutilainen 2001). The fields are amended with lime at $4 \mathrm{t} \mathrm{ha}^{-1}$ every fifth year, and the production and transportation of lime consumes $0.5 \mathrm{GJ} \mathrm{t}^{-1}$ of primary energy (Mäkinen et al. 2006). The manufacturing of the herbicides consumes $274 \mathrm{MJ} \mathrm{kg}^{-1}$ of primary energy (Mäkinen et al. 2006, Gerin et al. 2008, Mikkola \& Ahokas 2009, Smyth et al. 2009). The manufacturing and transportation of the fertilizer (Y3 NPK 20-3-8, Kemira GrowHow, Helsinki) used 11.9 GJ t$^{-1}$ of primary energy (Mäkinen et al. 2006). When the digestate is used as a fertilizer, the loading and transportation of the digestate to the field is considered. The loading of the digestate consumes $2.5 \mathrm{MJ} \mathrm{t}^{-1}$ of primary energy and the transportation consumes 
4.9 $\mathrm{MJ} \mathrm{t}^{-1}$ (Berglund \& Börjesson 2006, Smyth et al. 2009). The production of seeds consumes $12 \mathrm{MJ} \mathrm{kg}^{-1}$ of primary energy (Kelm et al. 2004, Smyth et al. 2009). 


\section{RESULTS}

\subsection{TS yields per hectare}

The TS yields of the different grass species were determined for all of the harvest times in 2005-2007 (I). The TS yields of the different grasses were from 1.1 to 13.7 tTS ha-1, and on an average $4.3 \mathrm{tTS} \mathrm{ha}^{-1}$ per harvest (Table 8). The TS yields per hectare per year of the different grasses in Hahkiala $\left(7.2 \mathrm{tTS} \mathrm{ha}^{-1} \mathrm{a}^{-1}\right)$ were higher than those in Saarijärvi $\left(6.3 \mathrm{tTS} \mathrm{ha}^{-1} \mathrm{a}^{-1}\right)$, but the difference was not statistically significant (t-test, $p>0.05$ ). In the first harvest year (2005) the average yield of all of the grasses in Saarijärvi was 3.8 tTS ha-1 $^{-1}$. However, the average TS yields increased from the $1^{\text {st }}$ to $2^{\text {nd }}\left(5.4\right.$ tTS ha $\left.^{-1} \mathrm{a}^{-1}\right)$ and $3^{\text {rd }}\left(9.8\right.$ tTS ha-1 $\left.\mathrm{a}^{-1}\right)$ harvest years. In the third harvest year, 2007, cocksfoot and tall fescue produced the highest TS yields per hectare per annum (11.5 and $\left.11.2 \mathrm{tTS} \mathrm{ha}^{-1} \mathrm{a}^{-1}\right)$, while the TS yield of reed canary grass $\left(6.8 \mathrm{tTS} \mathrm{ha}^{-1} \mathrm{a}^{-1}\right)$ was lower than in the $1^{\text {st }}$ and $2^{\text {nd }}$ harvest years in Saarijärvi.

The TS yields of various maize varieties were determined in 2007 and 2008 (II). The average TS yield was $16.6 \mathrm{tTS} \mathrm{ha}^{-1}$ in Piikkiö and $8.1 \mathrm{tTS} \mathrm{ha}^{-1}$ in Laukaa (t-test, $p<0.05$ ) (Table 9). The average TS yields were $9 \%$ higher at the $2^{\text {nd }}$ harvest time (A2) in 2007 than at the $1^{\text {st }}$ harvest time (A1), but the difference was not statistically significant (Bonferroni, all $p$ values $>0.05$ ). The sowing time (B) did not affect the average TS yields per hectare (ANOVA, all $p$ values $>0.05$ ). Amara produced the highest average TS yields $\left(20.1 \mathrm{tTS} \mathrm{ha}^{-1}\right)$ in 2007, and the TS yield of Amara was the second highest $\left(17.8 \mathrm{t} \mathrm{ha}^{-1}\right)$ after the TS yield of KXA7254 (18.1 tTS ha-1) in 2008. Amadeo and Ronaldinio produced the lowest TS yields (2007: 14.0 and 14.3 tTS ha-1 and 2008: 11.6 and 13.4 tTS ha-1) in both cultivation years in Piikkiö (Table 9).

The average TS yields of various plant parts were determined for Francisco, Amara, Marcello, Cerruti, and MAS09A in 2007 (Table 10; II). The stems, leaves, and cobs produced on average $(n=11) 7.7,2.9$ and 5.6 tTS ha $^{-1}$, respectively (Table 10). The fraction of stems and leaves (vegetative plant fractions) decreased (from 8.6 to 7.3 tTS ha $^{-1}$ with stems and from 3.2 to 2.8 tTS ha- $^{-1}$ with leaves) with 
the increasing maturity of the maize. Furthermore, the amount of cobs increased from 5.3 to $8.6 \mathrm{tTS} \mathrm{ha}^{-1}$ (t-test, $p<0.05$ ) (Table 10). The sowing time (A or B) did not affect the TS yield per hectare of stems, leaves and cobs (ANOVA, all $p$ values $>0.05$ ).

TABLE 8 Specific methane yields, TS yields and characteristics (SCOD, $\mathrm{N}_{\text {tot }}$ and $\mathrm{NH}_{4}-\mathrm{N}$ ) of grasses (I). Specific methane yields are given as mean \pm SD.

\begin{tabular}{|c|c|c|c|c|c|c|c|}
\hline \multirow[t]{2}{*}{ Grass material } & \multicolumn{3}{|c|}{ Specific methane yield } & \multirow{2}{*}{$\begin{array}{c}\text { TS yield } \\
\mathrm{t} \mathrm{ha}^{-1}\end{array}$} & \multirow{2}{*}{$\begin{array}{c}\text { SCOD } \\
\text { mg gTS- }^{-1}\end{array}$} & \multirow{2}{*}{$\begin{array}{c}\mathrm{N}_{\text {tot }} \\
\text { mg gTS-1 }^{-1}\end{array}$} & \multirow{2}{*}{$\begin{array}{l}\mathrm{NH}_{4}-\mathrm{N} \\
\text { mg gTS }^{-1}\end{array}$} \\
\hline & $1 \mathrm{kgVS}^{-1}$ & $1 \mathrm{kgTS}^{-1}$ & $1 \mathrm{kgWW}^{-1}$ & & & & \\
\hline CF SA 05 & $380 \pm 25$ & 330 & 63 & 2.3 & 85 & 21.8 & 0.16 \\
\hline CF SA 06 & $350 \pm 20$ & 310 & 120 & 5.6 & 110 & 33.3 & 0.63 \\
\hline CF HA $062^{\text {nd }}$ & $320 \pm 36$ & 290 & 94 & 2.3 & 171 & 21.0 & 0.13 \\
\hline CF HA $063^{\text {rd }}$ & $310 \pm 14$ & 250 & 56 & 3.2 & 135 & 21.8 & 0.16 \\
\hline CF SA $071^{\text {st }}$ & $360 \pm 14$ & 330 & 76 & 6.4 & 50 & 10.8 & 0.06 \\
\hline CF SA $072^{\text {nd }}$ & $330 \pm 5$ & 300 & 53 & 5.1 & 72 & 19.4 & 0.47 \\
\hline TF SA 05 & $300 \pm 25$ & 270 & 58 & 1.1 & 110 & 21.3 & 0.33 \\
\hline TF SA 06 & $390 \pm 25$ & 350 & 150 & 4.3 & 126 & 36.7 & 0.86 \\
\hline TF HA $062^{\text {nd }}$ & $310 \pm 34$ & 280 & 93 & 3.2 & 168 & 17.5 & 0.16 \\
\hline TF HA $063^{\text {rd }}$ & $310 \pm 23$ & 280 & 67 & 3.5 & 149 & 21.5 & 0.33 \\
\hline TF SA $071^{\text {st }}$ & $360 \pm 24$ & 330 & 74 & 6.0 & 178 & 18.4 & 0.08 \\
\hline TF SA $072^{\text {nd }}$ & $350 \pm 3$ & 320 & 55 & 5.2 & 35 & 14.5 & 0.06 \\
\hline TIM HA $061^{\text {st }}$ & $370 \pm 6$ & 340 & 76 & 3.8 & 165 & 21.1 & 0.14 \\
\hline TIM HA $062^{\text {nd }}$ & $360 \pm 33$ & 330 & 120 & 2.7 & 186 & 17.5 & 0.11 \\
\hline TIM HA3 $062^{\text {nd }}$ & $310 \pm 53$ & 290 & 100 & 1.5 & 171 & 23.1 & 0.18 \\
\hline TIM HA3 $063^{\text {rd }}$ & $310 \pm 51$ & 280 & 55 & 2.1 & 110 & 28.6 & 0.44 \\
\hline RCG SA $051^{\text {st }}$ & $330 \pm 16$ & 300 & 65 & 5.2 & 41 & 24.3 & 0.14 \\
\hline RCG SA $052^{\text {nd }}$ & $250 \pm 12$ & 230 & 52 & 2.9 & 92 & 15.4 & 0.20 \\
\hline RCG SA 06 a & $320 \pm 23$ & 280 & 120 & 4.2 & 92 & 19.7 & 0.96 \\
\hline RCG SA 06 b & $260 \pm 29$ & 240 & 64 & 7.5 & 40 & 11.0 & 0.09 \\
\hline RCG SA $071^{\text {st }}$ & $350 \pm 10$ & 310 & 77 & 3.4 & 46 & 21.4 & 0.25 \\
\hline RCG SA $072^{\text {nd }}$ & $250 \pm 39$ & 240 & 47 & 3.4 & 39 & 17.1 & 0.11 \\
\hline RCG HA 07 & $250 \pm 39$ & 210 & 100 & 13.7 & 123 & 8.1 & 0.14 \\
\hline
\end{tabular}

The TS yields of the novel energy crops were determined in 2006-2010 (IV). The TS yields per hectare varied from 6.5 to $23.4 \mathrm{tTS} \mathrm{ha}^{-1}$. The highest annual TS yields were for brown knapweed at 20.2-23.4 tTS ha-1 (B07, C07) and giant goldenrod at 22.7 tTS ha-1 $^{-1}$ (Table 11). The TS yields of brown knapweed increased from the first harvest $\left(9.4 \mathrm{tTS} \mathrm{ha}^{-1}, \mathrm{~A} 08\right)$ to the third harvest time (23.4 tTS ha-1, C08) in 2008, while in the fourth (last) harvest time (D08), the TS yield decreased (10.9 tTS ha-1). The TS yield of giant knotweed was not measured in 
this study, but the TS yields were 14.6, 24.1 and $27.6 \mathrm{tTS} \mathrm{ha}^{-1}$ (on average $22.1 \mathrm{tTS}$ $\mathrm{ha}^{-1}$ ) (Table 11) for harvests in July, August and September, respectively, at the research centre of MTT Agrifood Research Finland in Piikkiö in 2012. 
TABLE 9 The number of leaves and cobs per maize plant, $\mathrm{N}_{\text {tot }}$ content, TS yield, specific methane yield and methane yields per hectare in maize varieties at different sowing and harvest times in 2007 and 2008 (II). Specific methane yields are given as mean $\pm \mathrm{SD}$.

\begin{tabular}{|c|c|c|c|c|c|c|c|}
\hline \multirow[t]{2}{*}{ Maize variety } & & \multicolumn{2}{|c|}{$\begin{array}{c}\text { Number } \\
\text { of }\end{array}$} & \multirow{2}{*}{$\begin{array}{c}\mathrm{N}_{\text {tot }} \\
\text { mg gTS-1 }^{-1}\end{array}$} & \multirow{2}{*}{$\begin{array}{c}\text { TS yield } \\
\text { t ha-1 }\end{array}$} & \multirow{2}{*}{$\begin{array}{l}\text { Specific } \\
\text { methane } \\
\text { yield } \\
1 \mathrm{kgVS}^{-1}\end{array}$} & \multirow{2}{*}{$\begin{array}{c}\text { Methane } \\
\text { yield }\end{array}$} \\
\hline & & leaves & cobs & & & & \\
\hline \multicolumn{8}{|c|}{ Maize varieties in Laukaa in 2007} \\
\hline Cerruti & & 10.5 & 2.5 & 11.9 & 10.0 & $410 \pm 23$ & 3900 \\
\hline MAS09A & & 10.2 & 2.0 & 13.5 & 7.4 & $420 \pm 19$ & 2800 \\
\hline \multicolumn{8}{|c|}{ Maize varieties in Piikkiö in 2007} \\
\hline \multirow[t]{3}{*}{ Francisco } & $\mathrm{A} 1^{\mathrm{a}}$ & 11.0 & 1.6 & 14.4 & 15.9 & $420 \pm 24$ & 6200 \\
\hline & $\mathrm{A} 2$ & 11.5 & 1.7 & 10.9 & 17.3 & $370 \pm 21$ & 6200 \\
\hline & B & 11.1 & 1.6 & 13.7 & 17.4 & $340 \pm 92$ & 5900 \\
\hline \multirow[t]{3}{*}{ Amara } & A1 & 12.0 & 2.0 & 10.3 & 19.4 & $410 \pm 58$ & 7400 \\
\hline & $\mathrm{A} 2$ & 12.5 & 1.6 & 12.5 & 20.0 & $430 \pm 28$ & 8300 \\
\hline & B & 12.0 & 1.8 & 15.6 & 21.0 & $440 \pm 9$ & 9200 \\
\hline \multirow[t]{3}{*}{ Marcello } & A1 & 11.6 & 2.1 & 15.2 & 16.1 & $380 \pm 89$ & 5700 \\
\hline & $\mathrm{A} 2$ & 11.7 & 2.2 & 11.8 & 18.8 & $460 \pm 75$ & 7500 \\
\hline & B & 12.3 & 1.9 & 14.4 & 14.7 & $420 \pm 32$ & 5800 \\
\hline \multirow[t]{2}{*}{ Ronaldinio } & A1 & 10.7 & 1.5 & 16.5 & 13.1 & $500 \pm 24$ & 6200 \\
\hline & B & 11.3 & 2.4 & 15.5 & 15.6 & $460 \pm 20$ & 6900 \\
\hline \multirow[t]{2}{*}{ Amadeo } & A1 & 10.5 & 1.5 & 16.0 & 14.0 & $440 \pm 74$ & 6000 \\
\hline & B & 10.3 & 1.6 & 18.5 & 14.0 & $430 \pm 50$ & 5700 \\
\hline \multirow[t]{2}{*}{ Sampaio } & A1 & 11.6 & 1.9 & 18.0 & 16.3 & $470 \pm 59$ & 7400 \\
\hline & B & 11.8 & 2.0 & 21.9 & 16.8 & $490 \pm 38$ & 8300 \\
\hline \multicolumn{5}{|c|}{ Average in Piikkiö in 2007} & 16.7 & $430 \pm 41$ & 6800 \\
\hline \multicolumn{8}{|c|}{ Maize varieties in Piikkiö in 2008} \\
\hline Amadeo & & 13.4 & 2.0 & 17.8 & 11.6 & $370 \pm 15$ & 4000 \\
\hline Ronaldinio & & 11.2 & 2.4 & 11.9 & 13.4 & $340 \pm 7$ & 4100 \\
\hline Amara & & 11.2 & 2.0 & 14.3 & 17.8 & $240 \pm 14$ & 3900 \\
\hline Valdez & & 14.6 & 1.6 & 15.2 & 16.7 & $360 \pm 7$ & 5600 \\
\hline XA 7251 & & 13.2 & 1.9 & 19.4 & 15.8 & $330 \pm 32$ & 4800 \\
\hline KXA 7254 & & 13.9 & 2.1 & 14.4 & 18.1 & $300 \pm 12$ & 4900 \\
\hline \multicolumn{5}{|c|}{ Average in Piikkiö in 2008} & 15.5 & $320 \pm 49$ & 4600 \\
\hline \multicolumn{8}{|c|}{ Maize variety in Laukaa in 2008} \\
\hline Revolver & & 10.1 & 0.0 & 21.6 & 6.8 & $330 \pm 130$ & 2100 \\
\hline
\end{tabular}


TABLE 10 The TS (\% WW), $\mathrm{N}_{\text {tot }}$ content $\left(\mathrm{mg} \mathrm{gTS}^{-1}\right)$, specific methane yields $\left(\mathrm{kgVS}^{-1}\right)$ and TS yield ( $\mathrm{t}$ ha $\left.{ }^{-1}\right)$ of various maize parts (stems, leaves, cobs) (II). Specific methane yields are given as mean \pm SD.

\begin{tabular}{|c|c|c|c|c|c|c|c|c|c|c|c|c|c|}
\hline \multirow{2}{*}{\multicolumn{2}{|c|}{ Maize variety }} & \multicolumn{3}{|c|}{\begin{tabular}{c}
\multicolumn{1}{c}{$\mathrm{TS}$} \\
$\% \mathrm{WW}$ \\
\end{tabular}} & \multicolumn{3}{|c|}{$\begin{array}{l}\text { TS yield } \\
\mathrm{t} \mathrm{ha}^{-1}\end{array}$} & \multicolumn{3}{|c|}{$\begin{array}{c}\text { Specific methane yield } \\
1 \mathrm{kgVS}^{-1}\end{array}$} & \multicolumn{3}{|c|}{$\begin{array}{c}\mathrm{N}_{\text {tot }} \\
\text { mg gTS-1 }^{-1}\end{array}$} \\
\hline & & Stems & Leaves & Cobs & Stems & Leaves & Cobs & Stems & Leaves & Cobs & Stems & Leaves & Cobs \\
\hline \multirow[t]{3}{*}{ Francisco } & $\mathrm{A} 1^{\mathrm{a}}$ & 18.7 & 13.5 & 15.8 & 8.0 & 3.1 & 4.7 & $300 \pm 40$ & $320 \pm 110$ & $290 \pm 71$ & 8.0 & 31.1 & 14.7 \\
\hline & $\mathrm{A} 2$ & 21.7 & 86.0 & 28.1 & 6.6 & 2.5 & 8.1 & $320 \pm 37$ & $360 \pm 33$ & $450 \pm 21$ & 4.2 & 21.5 & 13.2 \\
\hline & B & 20.2 & 31.5 & 15.7 & 8.9 & 3.2 & 5.2 & $360 \pm 64$ & $270 \pm 92$ & $330 \pm 48$ & 8.4 & 30.3 & 13.2 \\
\hline \multirow[t]{3}{*}{ Amara } & A1 & 21.6 & 26.0 & 18.0 & 10.4 & 3.7 & 5.3 & $380 \pm 17$ & $270 \pm 98$ & $330 \pm 125$ & 6.0 & 37.9 & 11.0 \\
\hline & $\mathrm{A} 2$ & 21.2 & 82.9 & 30.2 & 8.2 & 3.0 & 8.8 & $440 \pm 30$ & $310 \pm 32$ & $420 \pm 36$ & 9.7 & 20.1 & 12.5 \\
\hline & B & 20.1 & 27.4 & 16.4 & 10.3 & 4.0 & 6.5 & $390 \pm 35$ & $370 \pm 49$ & $480 \pm 29$ & 9.2 & 39.6 & 12.0 \\
\hline \multirow[t]{3}{*}{ Marcello } & A1 & 19.4 & 23.4 & 18.0 & 7.3 & 2.7 & 6.0 & $410 \pm 14$ & $400 \pm 15$ & $420 \pm 28$ & 9.4 & 34.1 & 11.1 \\
\hline & A2 & 21.0 & 81.0 & 30.8 & 7.2 & 2.7 & 8.9 & $310 \pm 32$ & $360 \pm 20$ & $410 \pm 66$ & 5.6 & 23.8 & 13.1 \\
\hline & B & 19.3 & 23.3 & 15.4 & 7.4 & 2.9 & 4.2 & $370 \pm 24$ & $370 \pm 81$ & $460 \pm 25$ & 8.1 & 30.6 & 14.7 \\
\hline Cerruti & & 20.0 & 20.0 & 12.0 & 5.5 & 1.9 & 2.6 & $360 \pm 35$ & $360 \pm 13$ & $390 \pm 80$ & 6.3 & 21.8 & 17.1 \\
\hline MAS09A & & 16.7 & 18.9 & 10.6 & 4.5 & 1.8 & 1.2 & $400 \pm 51$ & $350 \pm 21$ & $450 \pm 12$ & 7.3 & 22.7 & 22.9 \\
\hline
\end{tabular}


TABLE $11 \quad \mathrm{~N}_{\text {tot }}$ contents, specific methane yields, harvest and methane yields per hectare of novel energy crops in 2007-2010 (IV). Specific methane yields per VS are given as mean $\pm \mathrm{SD}$.

\begin{tabular}{|c|c|c|c|c|c|c|c|}
\hline \multicolumn{2}{|l|}{ Plant species } & \multirow{2}{*}{$\begin{array}{c}\mathrm{N}_{\text {tot }} \\
\mathrm{mg} \mathrm{gTS}^{-1}\end{array}$} & \multirow{2}{*}{$\begin{array}{c}\text { TS } \\
\text { yield } \\
\text { t ha-1 }^{-1}\end{array}$} & \multicolumn{3}{|c|}{ Specific methane yield } & \multirow{2}{*}{$\begin{array}{c}\text { Methane } \\
\text { yield } \\
\mathrm{m}^{3} \mathrm{ha}^{-1}\end{array}$} \\
\hline & & & & $1 \mathrm{kgVS}^{-1}$ & $1 \mathrm{kgTS}^{-1}$ & $1 \mathrm{kgWW}^{-1}$ & \\
\hline \multicolumn{2}{|l|}{ Jerusalem artichoke } & 5.1 & n.d. & $340 \pm 47$ & 310 & 100 & n.d. \\
\hline \multicolumn{2}{|l|}{ Sunflower } & 6.6 & n.d. & $380 \pm 56$ & 340 & 50 & n.d. \\
\hline \multirow[t]{6}{*}{ Brown knapweed } & $\mathrm{A} 07^{\mathrm{a}}$ & n.d. & n.d. & $360 \pm 32$ & 330 & 58 & n.d. \\
\hline & B07 & n.d. & 15.8 & $220 \pm 4$ & 200 & 69 & 3200 \\
\hline & A08 & 19.8 & 9.4 & $320 \pm 53$ & 290 & 53 & 2700 \\
\hline & B08 & 11.2 & 20.2 & $330 \pm 41$ & 300 & 72 & 6100 \\
\hline & $\mathrm{C} 08$ & 10.4 & 23.4 & $280 \pm 18$ & 260 & 78 & 6100 \\
\hline & D08 & 10.7 & 10.9 & $170 \pm 26$ & 180 & 78 & 2000 \\
\hline \multicolumn{2}{|l|}{ Sorghum } & 23.2 & 8.6 & $330 \pm 62$ & 290 & 50 & 2500 \\
\hline \multicolumn{2}{|l|}{ Japanese millet } & 16.9 & 13.9 & $340 \pm 16$ & 310 & 46 & 4300 \\
\hline \multicolumn{2}{|l|}{ Giant knotweed } & 8.9 & $22.1^{b}$ & $170 \pm 25$ & 160 & 48 & 3400 \\
\hline \multicolumn{2}{|l|}{ Giant goldenrod } & 7.2 & 22.7 & $190 \pm 65$ & 170 & 68 & 3900 \\
\hline \multicolumn{2}{|l|}{ Hemp-agrimony } & 11.0 & 6.5 & $210 \pm 7$ & 190 & 51 & 1200 \\
\hline \multicolumn{2}{|l|}{ Amaranth } & 18.5 & 11.3 & $290 \pm 25$ & 240 & 43 & 2700 \\
\hline
\end{tabular}

aA, B, C, D are different harvest times in year 2007 and 2008.

bAverage TS yield in the year 2012 .

n.d. not determined

\subsection{Characteristics of energy crops}

The chemical characteristics of the different grass species and different harvests were determined (Table 2; I). The TS content varied from $17.4 \%$ in cocksfoot (CF SA $072^{\text {nd }}$ ) and tall fescue (TF SA $072^{\text {nd }}$ ) to $43.7 \%$ (TF SA 06). TS content in the second harvest was lower than in the first harvest for almost every grass species and every harvest year. The high TS content of cocksfoot (CF SA 06), tall fescue (TF SA 06) and reed canary grass (RCG SA 06a) in Saarijärvi are apparently the consequence of pre-wilting ( $24 \mathrm{~h}$ on the field) of the grasses. The VS/TS ratio varied from 0.82 to 0.93 , and the total nitrogen content varied from $8.1 \mathrm{mg} \mathrm{gTS}^{-1}$ to $36.7 \mathrm{mg} \mathrm{gTS}^{-1}$ (Table 8).

The TS and VS content and amount of leaves and cobs were determined in both growing seasons from maize material (II). The TS content of all maize varieties increased due to the maize varieties maturing in 2007. The average TS content at harvest time for A1 was $19.8 \%$ and for A2 $28.0 \%$ (Table 3). The TS and VS contents of the maize varieties cultivated in Piikkiö were higher than those of the maize varieties in Laukaa (Cerruti, MAS09A and Revolver). The total nitrogen content varied from 10.3 to $21.9 \mathrm{mg} \mathrm{gTS}^{-1}$. There was an average of 2 cobs per maize plant for all maize varieties (Table 9), and only the Revolver had 
not produced any cobs by the point of harvest (Table 9). The average amount of leaves was 12 leaves per maize plant. The Revolver, Cerruti, and MAS09A (cultivated in Laukaa) had only 10 leaves per plant. Amara, Valdez, KXA7251 and KXA7254 had more than 13 leaves per plant in 2008, which was greater than the other maize varieties (Bonferroni, all $p$ values $<0.05$ ) (Table 9).

The TS and VS content and $\mathrm{N}_{\text {tot }}$ contents were also determined from the different plant parts, stems, leaves and cobs (II). The determined TS concentration in the stems was $20.0 \%$ on average, and it did not change while the plants were maturing (Table 10). The TS content for the leaves was at its highest $(83.3 \%)$ in the second harvest (A2), when the leaves near the ground were already in senescence (Table 10). When the cobs matured, the TS content of the cobs increased from 17.2 to $29.7 \%$. The same increases and decreases also occurred in the VS contents of the various plant parts. The $\mathrm{N}_{\text {tot }}$ content of the various maize parts were, on average, $7.5,28.5$ and $14.1 \mathrm{mg} \mathrm{gTS}^{-1}$ in the stems, leaves and cobs, respectively (Table 10). When the maize species matured (harvest A1 to A2), the $\mathrm{N}_{\text {tot }}$ content decreased in the leaves (Bonferroni, all $p$ values $<0.05$ ) and remained stable in the stems and cobs (Table 10).

The characteristics of nine novel energy crops were determined in 20072010 (IV). The TS content varied from 14.7 to $42.9 \%$, and VS content from 13.0 to $39.4 \%$ (Table 4). The TS content of the brown knapweed more than doubled during the growing season, from 17.7 to $34.3 \%$ TS in 2007 and from 18.1 to 42.9 $\%$ TS in 2008. The increases in the TS and VS contents were significant during the growing season (Bonferroni, all $p$ values $<0.05$ ), with the exception of the first harvests in the growing seasons (A07 and A08) (Bonferroni, all $p$ values $>0.05$ ). SCOD $\left(91.7,177.1,146.0\right.$ and $\left.194.5 \mathrm{mg} \mathrm{gTS}^{-1}\right)$ and $\mathrm{NH}_{4}-\mathrm{N}(0.25,0.27,0.19,0.38 \mathrm{mg}$ gTS $^{-1}$ ) were determined in harvests A08, B08, C08, and D08 in brown knapweed in 2008, respectively. $\mathrm{N}_{\text {tot }}$ content varied from 5.1 to $23.2 \mathrm{mg} \mathrm{gTS}^{-1}$. The highest $\mathrm{N}_{\text {tot }}$ content was for sorghum at $23.2 \mathrm{mg} \mathrm{gTS}^{-1}$ (Table 11). The TS content of giant knotweed was 20.8, 27.2 and $36.6 \%$ TS for the harvests in July, August and September, respectively, at the research centre of MTT Agrifood Research Finland in Piikkiö in 2012.

\subsection{Specific methane yields}

\subsubsection{Specific methane yields of grasses}

The specific methane yields of the different grass species were determined from the $1^{\text {st }}, 2^{\text {nd }}$ and $3^{\text {rd }}$ harvests, depending on cultivation site and grass species (I). The specific methane yields of all grasses and all harvests varied from 250 to 3901 $\mathrm{kgVS}^{-1}$ (Table 8). Average specific methane yields across all harvests of cocksfoot, tall fescue and timothy were, on average, 342, 336 and $3351 \mathrm{kgVS}^{-1}$, respectively (Bonferroni, all $p$ values $>0.05$ ), and for reed canary grass the specific methane yield was lower $\left(300 \mathrm{l} \mathrm{kgVS}^{-1}\right)$ than the others (Bonferroni, all $p$ values < 0.05 ). 
The highest specific methane yield $\left(3901 \mathrm{kgVS}^{-1}\right)$ was achieved with the tall fescue harvest in late June in 2006 (TF SA 06) (Table 8).

The effect of harvest time on the specific methane yields was evaluated in the early flowering stage (generative growth stage, $1^{\text {st }}$ harvest) and the vegetative growth stage (2nd harvest) (I). The average specific methane yield of the $1^{\text {st }}$ harvest of all grasses was higher than in the $2^{\text {nd }}$ harvest (Table 8). When comparing the harvest time only for the reed canary grass and cocksfoot, the specific methane yields were significantly higher in the $1^{\text {st }}$ than in the $2^{\text {nd }}$ harvest (Bonferroni, all $p$ values $<0.05$ ) while the difference was not statistically significant in the timothy and tall fescue (Bonferroni, all $p$ values $>0.05$ ). The specific methane yield of the reed canary grass also decreased when harvested (2006) in the early flowering stage, and flowering stages from different plots (ttest, $p=0.052)$. The specific methane yields of the grass species did not differ between the harvest years (ANOVA, all $p$ values $>0.05$ ).

\subsubsection{Specific methane yields of maize varieties}

The specific methane yields of various maize varieties of different harvest and sowing times were determined in the batch assays in 2007 and 2008 (II). The specific methane yields of the various maize varieties were determined at two harvest times (A1 and A2) and the sowing time (B) in 2007, and at one harvest time in 2008. The specific methane yields of the maize varieties varied from 340 to $500 \mathrm{l} \mathrm{kgVS}^{-1}$ in 2007, and from 240 to $370 \mathrm{l} \mathrm{kgVS}^{-1}$ in 2008 (Table 9). The harvest and sowing time did not affect the specific methane yields (ANOVA, all $p$ values $>0.05$ ).

The specific methane yields were also determined separately from the stem, leaves and cobs in the maize varieties Francisco, Amara, Marcello, Cerruti and MAS09A in the year 2007 (II). The stems, leaves, and cobs produced, on average, 370, 330 and $4201 \mathrm{kgVS}^{-1}$, respectively, when all harvest and sowing times were included (Table 10). The cobs produced more methane than the stems (Bonferroni, all $p$ values < 0.05) and leaves (Bonferroni, all $p$ values < 0.05), however, the harvest and sowing time did not affect the specific methane yields of the various plant parts (ANOVA, all $p$ values $>0.5$ ). The maize variety did not affect the specific methane yield of the various plant parts (ANOVA, all $p$ values $>0.05$ ). The specific methane yields of the various plant parts of the Cerruti and MAS09A varieties in Laukaa did not differ from the specific methane yields of the maize varieties in Piikkiö (ANOVA, all $p$ values $>0.05$ ).

\subsubsection{Specific methane yields of novel energy crops}

The specific methane yields were measured for nine novel energy crops cultivated in Piikkiö during the years 2007-2010 and for different harvest times of brown knapweed (two harvest times in 2007 and four in 2008) (IV). The specific methane yields varied from 170 to $3801 \mathrm{kgVS}^{-1}$ (Table 11). The highest specific methane yields were for sunflower at $3801 \mathrm{kgVS}^{-1}$ and brown knapweed (A07) at $3601 \mathrm{kgVS}^{-1}$ (Table 2), while the lowest yield was for giant knotweed 
(170 $\left.1 \mathrm{kgVS}^{-1}\right)$, which was statistically significant compared to sunflower (Bonferroni, $p=0.007$ ).

The specific methane yield of brown knapweed was measured at four different harvest times during the 2008 growing season. (IV). The specific methane yield of brown knapweed decreased at the beginning of July, from 3301 $\mathrm{kgVS}^{-1}$, to below $2001 \mathrm{kgVS}^{-1}$ at the beginning of September in 2008 (Table 11). The decrease in the specific methane yields was statistically significant in 2007 (ttest, $p=0.002)$, and the specific methane yields in A08 (320 $\left.1 \mathrm{kgVS}^{-1}\right)$ and B08 (330 $\left.1 \mathrm{kgVS}^{-1}\right)$ were higher than D08 (170 $\left.1 \mathrm{kgVS}^{-1}\right)$ (Bonferroni, all $p$ values < 0.05) (Table 11).

\subsection{The methane yields per hectare}

The methane yields per hectare for each harvest were calculated using the TS yields and the specific methane yields of the grass species and harvests (I). The highest methane yield was recorded for reed canary grass in 2007 (RCG HA 07) at $3500 \mathrm{~m}^{3} \mathrm{CH}_{4}$ ha $^{-1}$ (Figure 5). Tall fescue (TF SA $071^{\text {st) }}$ ) and cocksfoot (CF SA 07 $1^{\text {st) }}$ produced, respectively, 2000 and $2100 \mathrm{~m}^{3} \mathrm{CH}_{4}$ ha $^{-1}$ per harvest in Saarijärvi. The methane yield per hectare of the $1^{\text {st }}$ harvest was always higher than the methane yield of the $2^{\text {nd }}$ harvest because of the higher TS yield and specific methane yields of the $1^{\text {st }}$ harvest (Table 8). Due to apparently low TS yields per hectare, the methane yields for some harvests of cocksfoot (CF SA 05, CF HA 06b), tall fescue (TF SA 05) and timothy (TIM HA3 $062^{\text {nd }}$ and $3^{\text {rd }}$ ) remained relatively low $\left(300-700 \mathrm{~m}^{3} \mathrm{CH}_{4} \mathrm{ha}^{-1}\right)$. The methane yields per hectare was dependent on the TS yield per hectare $(r=0.97, p<0.01)$ while there was no correlation between specific methane yields and methane yields per hectare $(\mathrm{r}=$ 0.141 ). When the grasses were harvested three times per year (grasses in Hahkiala), the methane yields per hectare was lower in the $2^{\text {nd }}$ than in the $3^{\text {rd }}$ harvest. 

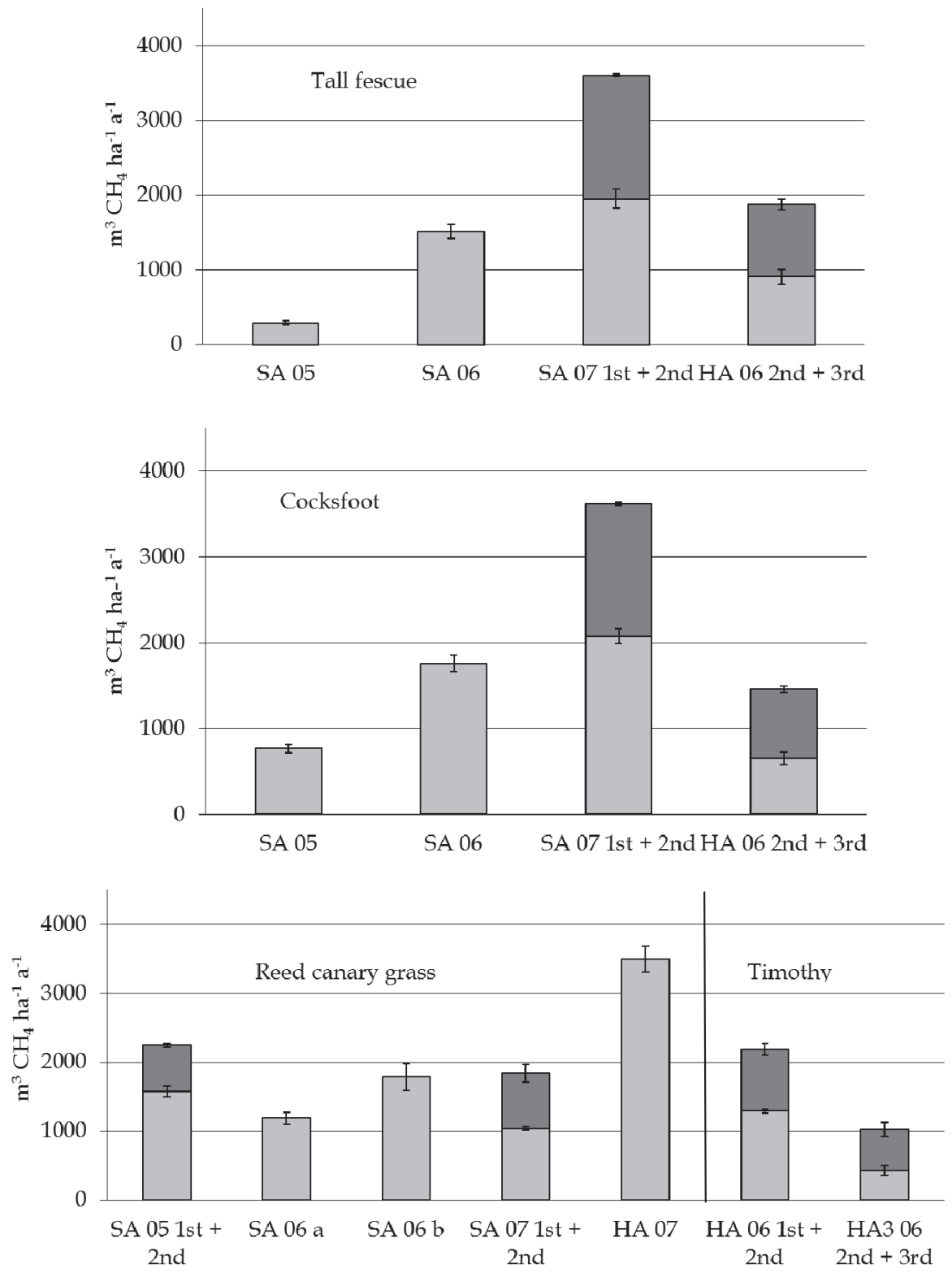

FIGURE 5 The methane yields $\left(\mathrm{m}^{3} \mathrm{CH}_{4}\right.$ ha-1) of tall fescue, cocksfoot, reed canary grass and timothy, per harvest time, and total annual methane yields $\left(\mathrm{m}^{3} \mathrm{CH}_{4} \mathrm{ha}^{-1} \mathrm{a}^{-1}\right)$ in Saarijärvi (SA) and Hahkiala (HA) in years 2005-2007. The error bars are standard deviations. 
Methane yields per hectare were calculated for each grass species (I). In 2007, the highest methane yields for cocksfoot and tall fescue in Saarijärvi, and for reed canary grass in Hahkiala, produced $3500-3600 \mathrm{~m}^{3} \mathrm{CH}_{4}$ ha $^{-1} \mathrm{a}^{-1}$ (Figure 5). Reed canary grass produced the highest methane yield of $2200 \mathrm{~m}^{3} \mathrm{CH}_{4} \mathrm{ha}^{-1} \mathrm{a}^{-1}$ in the first harvesting year in Saarijärvi, while the methane yields in the $2^{\text {nd }}$ and $3^{\text {rd }}$ harvesting years stayed at the same level, due to the fact that the TS yields per hectare did not increase like they did in the case of cocksfoot and tall fescue. If the $1^{\text {st }}$ harvest was collected for other than energy purposes (for example, animal feed), then the tall fescue and cocksfoot (TF HA $062^{\text {nd }}$ and $3^{\text {rd }}$ and CF HA $062^{\text {nd }}$ and $3^{\text {rd }}$ ) would produce $1500-1900 \mathrm{~m}^{3} \mathrm{CH}_{4} \mathrm{ha}^{-1} \mathrm{a}^{-1}$.

The methane yields per hectare were calculated using the specific methane yield and TS yield per hectare of each maize variety and harvest time (II). The methane yields per hectare varied from 2130 to $9170 \mathrm{~m}^{3} \mathrm{CH}_{4} \mathrm{ha}^{-1} \mathrm{a}^{-1}$ (Table 9). The highest methane yields per hectare were, on average, from Amara (9170 $\mathrm{m}^{3} \mathrm{CH}_{4} \mathrm{ha}^{-1} \mathrm{a}^{-1}$ ), which was higher than the methane yields of Francisco, Marcello, Amadeo, MAS09A and Cerruti (Bonferroni, all $p$ values < 0.05) in 2007 (Table 9). The later harvest (A2) produced, on average, more methane per hectare $\left(7300 \mathrm{~m}^{3} \mathrm{CH}_{4} \mathrm{ha}^{-1} \mathrm{a}^{-1}\right)$ than the first harvest (A1) $\left(6400 \mathrm{~m}^{3} \mathrm{CH}_{4} \mathrm{ha}^{-1} \mathrm{a}^{-1}\right)$, but it was not statistically significant (Bonferroni, all $p$ values $>0.05$ ). The maize varieties in Piikkiö produced twice the amount of methane per hectare than the maize varieties in Laukaa in both cultivation years (t-test, all $p$ values $<0.05$ ). The methane yields per hectare were higher in 2007 than in 2008 in Piikkiö (Table 9). In 2008, Valdez had the highest methane yield per hectare $\left(5600 \mathrm{~m}^{3} \mathrm{CH}_{4} \mathrm{ha}^{-1} \mathrm{a}^{-1}\right)$, compared with Amadeo, Ronaldinio, and Amara (Bonferroni, all $p$ values $<0.05$ ).

The stems and cobs produced the highest methane yields per hectare, with a total average of $2900 \mathrm{~m}^{3} \mathrm{CH}_{4} \mathrm{ha}^{-1} \mathrm{a}^{-1}$ and $2300 \mathrm{~m}^{3} \mathrm{CH}_{4} \mathrm{ha}^{-1} \mathrm{a}^{-1}$, which were, proportionally, $48 \%$ and $37 \%$ of the whole plant methane yields per hectare, respectively. The leaves produced, on average, only $860 \mathrm{~m}^{3} \mathrm{CH}_{4} \mathrm{ha}^{-1} \mathrm{a}^{-1}(15 \%$ of the total methane yield per hectare). However, the later harvest time (A2) increased the proportion of methane yields for the cobs from $35 \%$ to $51 \%$, while the proportion of the methane yields of the stems decreased from $50 \%$ to $36 \%$. The methane yields per hectare were lower, calculating for the specific methane yields and TS yields of the plant parts, rather than using the specific methane yield of the whole plant, and the TS yield of the whole plant biomass.

The methane yields per hectare of nine novel energy crops were calculated (IV), and varied from 1200 to $6100 \mathrm{~m}^{3} \mathrm{CH}_{4} \mathrm{ha}^{-1} \mathrm{a}^{-1}$ (Table 11). The highest methane yield was achieved with brown knapweed at $6100 \mathrm{~m}^{3} \mathrm{CH}_{4} \mathrm{ha}^{-1} \mathrm{a}^{-1}$, and harvested in July (B08) and August (C08) in 2008 (Table 11). The second highest methane yield per hectare was achieved with Japanese millet $\left(4300 \mathrm{~m}^{3} \mathrm{CH}_{4} \mathrm{ha}^{-1}\right.$ $\mathrm{a}^{-1}$ ) and giant knotweed (2 300-4 $\left.300 \mathrm{~m}^{3} \mathrm{CH}_{4} \mathrm{ha}^{-1} \mathrm{a}^{-1}\right)$. However, the methane yield per hectare of giant knotweed was low, although it had high TS yields per hectare (on average, $22.1 \mathrm{tTS} \mathrm{ha}^{-1}$ ), because the specific methane yield was low (Table 11). 


\subsection{Co-digestion of maize and brown knapweed with liquid cow manure}

The CSTR experiments, conducted on maize (variety Valdez) (Table 12; III) and brown knapweed (harvested 7.7.2008) (Table 13; IV), were run for 136 days to evaluate the methane potential and the process performance of the co-digestion of brown knapweed and maize, with liquid cow manure, in three parallel CSTR reactors (III, IV). Reactor 1 (R1) was first fed with liquid cow manure only, and the OLR was constant at $2 \mathrm{kgVS} \mathrm{m}^{-3} \mathrm{~d}^{-1}$ (Table 13). Two other reactors (R2 and R3) were first fed with the feedstock containing $20 \%$ (R2) and $50 \%$ (R3) of VS maize (III) (Table 12). The OLR in all of the reactors was, at first, $2 \mathrm{kgVS} \mathrm{m}^{-3} \mathrm{~d}^{-1}$. After 42 days, the R1 began to be fed with liquid cow manure and brown knapweed. The share of brown knapweed was $20 \%$ of the feed VS, and the HRT was 28 days (IV; Table 13). On days 98-140, the share of brown knapweed was increased to $50 \%$ of the feed VS (Table 13). In R2, the share of maize was first increased to $30 \%$, and subsequently to $40 \%$ on day 98 of the feed VS, while maintaining the OLR of $2 \mathrm{~kg} \mathrm{VS} \mathrm{m}^{-3} \mathrm{~d}^{-1}$, HRT 27-30 d (Table 12). In R3, the share of maize was increased from $50 \%$ to $60 \%$ of the feed VS, and the OLR was 2.5 $\mathrm{kgVS} \mathrm{m}^{-3} \mathrm{~d}^{-1}$ on day 42 . After that, on day 84 , the share of maize was increased to $67 \%$ of the feed VS, and the OLR was $3 \mathrm{kgVS} \mathrm{m}^{-3} \mathrm{~d}^{-1}$ with the HRT being 25 days (Table 12).

The share of maize in the feed increased the methane yield in the reactors. With a stable process performance, the highest methane yield $\left(2591 \mathrm{kgVS}^{-1}\right)$ was obtained when the share of the maize in the feed VS was $40 \%$ (R2), and the second highest methane yield was obtained when the proportion of maize in the feed VS was $60 \%$ (234 $\left.1 \mathrm{kgVS}^{-1}\right)$ (Fig. 6, Table 12). With brown knapweed, the highest methane yield was $2541 \mathrm{kgVS}^{-1}$ ( $50 \%$ brown knapweed from feed). For brown knapweed, the methane yields were $94-105 \%$ of the calculated specific methane yield of the feed determined in the batch assays (Table 13), and in maize it was 76-95\%, when the process was stable. The lowest methane yield $(153 \pm 461$ $\mathrm{kgVS}^{-1}$ ) was due to the apparent overloading of R3, when the share of maize was $67 \%$ of the feedstock VS (Table 12). The methane yield of manure (R1) was $193 \pm$ $21 \mathrm{kgVS}^{-1}$. The methane content of the produced biogas was $41-57 \%$ (Table 12 and 13).

The contents of digestate were analysed during the reactor experiments. The VFA, $\mathrm{NH}_{4}-\mathrm{N}$ and SCOD concentrations in the digestate of the reactor remained at low levels (III, IV) (Fig. 6, Table 12, 13), except in the R3 during overloading (maize $67 \%$ ) (III). The $\mathrm{pH}$ of the digestates was about 7.5 during the experiment (Fig. 6, Table 12, 13), but in the R3, the $\mathrm{pH}$ dropped to an average of 6.9 during overloading (III). The SCOD ranged from 8.7 to $12.7 \mathrm{~g} \mathrm{l}^{-1}$, while the total volatile fatty acids (VFA tot) concentrations were generally less than $1100 \mathrm{mg}$ $1^{-1}$, except with maize at $30 \%$ (R2), when the VFA tot concentration was higher (1 $918 \mathrm{mg} \mathrm{l}^{-1}$ ) due to some feeding problems with the syringe while operating the reactor (Fig. 6). Also during the overloading, the VFA tot concentration was high 
$4854 \pm 798 \mathrm{mg} \mathrm{l}^{-1}$, when the $67 \%$ feed VS was maize (Fig. 6, Table 12; III), consisting mainly of acetate (3950 $\left.\mathrm{mg} \mathrm{l}^{-1}\right)$ and propionate $\left(980 \mathrm{mg} \mathrm{l}^{-1}\right)$. During the trials in the three reactors, the $\mathrm{NH}_{4}-\mathrm{N}$ concentration of the digestate varied from 0.53 to $0.87 \mathrm{~g} \mathrm{l}^{-1}$ (Fig. 6), and the $\mathrm{N}_{\text {tot }}$ varied from 1.9 to $2.5 \mathrm{~g} \mathrm{l}^{-1}$, indicating decreasing trends during the trials due to the lower nitrogen content of maize and brown knapweed when compared with manure and the inoculum (Table 6, Fig. 6). TS and VS removals were calculated for all operational conditions in the reactors. TS removal was $16 \%$ and VS removal $21 \%$ of the liquid cow manure reactor (R1). When the maize was increased in the feed (the share of maize at 30 $\%$ in the feed), the TS and VS removals increased to $28 \%$ and $36 \%$, respectively. When the share of brown knapweed was $20 \%$ in the feed, the TS and VS removals were $25 \%$ and $33 \%$, respectively, and increased to $42 \%$ TS and $48 \%$ VS, when the share of brown knapweed was $50 \%$ VS in the feed (Table 12, 13), showing the higher degradation of the plant material than the liquid cow manure. 
TABLE 12 Operational conditions, feedstock and digestate characteristics, and methane and post-methanation production in the CSTR experiments for maize and liquid cow manure (III). Standard deviation is given after \pm .

\begin{tabular}{|c|c|c|c|c|c|c|c|}
\hline \multirow{3}{*}{\multicolumn{2}{|c|}{$\begin{array}{l} \\
\text { Reactor } \\
\text { Feeding regime (FR) }\end{array}$}} & \multicolumn{3}{|c|}{$\begin{array}{c}\text { Cow manure and maize } \\
\text { low feed }\end{array}$} & \multicolumn{3}{|c|}{$\begin{array}{l}\text { Cow manure and maize } \\
\text { high feed }\end{array}$} \\
\hline & & \multicolumn{3}{|c|}{ R2 } & \multicolumn{3}{|c|}{ R3 } \\
\hline & & I & II & III & I & II & III \\
\hline \multicolumn{8}{|c|}{ Share of maize } \\
\hline & $\% \mathrm{VS}$ & 20 & 30 & 40 & 50 & 60 & 67 \\
\hline & $\% \mathrm{WW}$ & 8 & 11 & 17 & 18 & 26 & 35 \\
\hline \multicolumn{8}{|c|}{ Share of recycled digestate } \\
\hline & $\% \mathrm{WW}$ & - & - & - & 29 & 15 & 6 \\
\hline OLR & $\mathrm{kgVS} \mathrm{m}^{-3} \mathrm{~d}^{-1}$ & 2 & 2 & 2 & 2 & 2.5 & 3 \\
\hline HRT & $\mathrm{d}$ & 27 & 28 & 30 & 25 & 25 & 25 \\
\hline Duration & $\mathrm{d}$ & $0-42$ & $43-91$ & $98-140$ & $0-42$ & $43-83$ & $84-126$ \\
\hline \multicolumn{7}{|l|}{ Feedstock } & 8.3 \\
\hline & VS \% & 5.4 & 5.4 & 5.9 & 5 & 6.3 & 7.5 \\
\hline & SCOD g $1^{-1}$ & 14.5 & 11.7 & 11.7 & 14.8 & 13.9 & 14.9 \\
\hline & $\mathrm{NH}_{4}-\mathrm{N} \mathrm{g} \mathrm{l}^{-1}$ & 0.67 & 0.45 & 0.33 & 0.63 & 0.41 & 0.32 \\
\hline & $\mathrm{N}_{\text {tot }} \mathrm{gl}^{-1}$ & 2.4 & 1.6 & 1.7 & 2.2 & 1.8 & 1.9 \\
\hline \multicolumn{8}{|c|}{ Digestate } \\
\hline & TS \% & $5.0 \pm 0.4$ & $4.5 \pm 0.1$ & $4.0 \pm 0.1$ & $4.7 \pm 0.0$ & $4.7 \pm 0.2$ & $4.9 \pm 0.1$ \\
\hline & VS \% & $3.9 \pm 0.4$ & $3.4 \pm 0.1$ & $3.1 \pm 0.1$ & $3.7 \pm 0.1$ & $3.7 \pm 0.2$ & $4.0 \pm 0.1$ \\
\hline & SCOD g $1^{-1}$ & $10.4 \pm 0.4$ & $12.2 \pm 1.0$ & $10.3 \pm 1.0$ & $10.5 \pm 0.8$ & $9.1 \pm 0.7$ & $12.7 \pm 1.0$ \\
\hline & $\mathrm{NH}_{4}-\mathrm{N} \mathrm{g} \mathrm{l}^{-1}$ & $\begin{array}{c}0.81 \pm \\
0.05\end{array}$ & $\begin{array}{c}0.84 \pm \\
0.03\end{array}$ & $\begin{array}{c}0.66 \pm \\
0.03\end{array}$ & $\begin{array}{c}0.79 \pm \\
0.04\end{array}$ & $\begin{array}{c}0.65 \pm \\
0.05\end{array}$ & $\begin{array}{l}0.53 \pm \\
0.05\end{array}$ \\
\hline & $\mathrm{N}_{\text {tot }} \mathrm{gl}^{\mathrm{l}^{-1}}$ & $2.5 \pm 0.1$ & $2.3 \pm 0.1$ & $1.9 \pm 0.1$ & $2.4 \pm 0.0$ & $2.2 \pm 0.1$ & $1.9 \pm 0.1$ \\
\hline & $\mathrm{pH}$ & $7.5 \pm 0.1$ & $7.4 \pm 0.1$ & $7.4 \pm 0.1$ & $7.47 \pm 0.1$ & $7.4 \pm 0.1$ & $6.9 \pm 0.3$ \\
\hline & $\mathrm{VFA}_{\text {tot }} \mathrm{mg} \mathrm{l}^{-1}$ & $\begin{array}{c}69 \pm \\
119\end{array}$ & $\begin{array}{c}1918 \pm \\
568\end{array}$ & $\begin{array}{c}55 \pm \\
22\end{array}$ & $\begin{array}{c}112 \pm \\
165\end{array}$ & $\begin{array}{c}1079 \pm \\
129\end{array}$ & $\begin{array}{c}4854 \pm \\
798\end{array}$ \\
\hline & Soluble $\mathrm{P} \mathrm{g}^{-1}$ & 0.16 & 0.15 & 0.18 & 0.13 & 0.15 & 0.21 \\
\hline & $P_{\text {tot }} \mathrm{g} \mathrm{l}^{-1}$ & 0.51 & 0.46 & 0.37 & 0.44 & 0.38 & 0.35 \\
\hline & $\mathrm{K}_{\text {tot }} \mathrm{g}^{-1}$ & 3.47 & 3.22 & 3.05 & 3.42 & 3.55 & 3.4 \\
\hline & TS removal \% & 22 & 28 & 41 & 18 & 32 & 41 \\
\hline & VS removal \% & 27 & 36 & 48 & 26 & 41 & 47 \\
\hline & $\mathrm{CH}_{4}$ con. $\%$ & $52 \pm 1$ & $44 \pm 6$ & $52 \pm 2$ & $51 \pm 3$ & $48 \pm 2$ & $41 \pm 9$ \\
\hline \multicolumn{8}{|c|}{ Calculated specific $\mathrm{CH}_{4}$ yield } \\
\hline & $1 \mathrm{kgVS}^{-1}$ & 241 & 256 & 271 & 286 & 301 & 311 \\
\hline \multicolumn{8}{|c|}{ Specific $\mathrm{CH}_{4}$ yield of } \\
\hline & $1 \mathrm{kgVS}^{-1}$ & $198 \pm 7$ & $194 \pm 84$ & $259 \pm 6$ & $221 \pm 14$ & $234 \pm 16$ & $153 \pm 46$ \\
\hline & $1 \mathrm{kgWW}^{-1}$ & $\begin{array}{c}10.7 \pm \\
0.4\end{array}$ & $\begin{array}{c}10.5 \pm \\
4.5\end{array}$ & $\begin{array}{c}15.3 \pm \\
0.3\end{array}$ & $\begin{array}{c}11.0 \pm \\
0.7\end{array}$ & $\begin{array}{c}14.6 \pm \\
1.0\end{array}$ & $\begin{array}{c}11.5 \pm \\
3.5\end{array}$ \\
\hline \multicolumn{8}{|c|}{$\%$ of total $\mathrm{CH}_{4}$ potential in substrates } \\
\hline & & 82 & 76 & 95 & 77 & 78 & 49 \\
\hline \multicolumn{8}{|c|}{ Post-methanation potential } \\
\hline & $1 \mathrm{kgVS}_{\text {feed }^{-1}}$ & n.a. & 99 & 75 & n.a. & 101 & 140 \\
\hline & $1 \mathrm{kgTS}_{\text {feed }^{-1}}$ & n.a. & 86 & 66 & n.a. & 92 & 127 \\
\hline & $1 \mathrm{kgWW}_{\text {feed }^{-1}}$ & n.a. & 5 & 4 & n.a. & 6 & 11 \\
\hline \multicolumn{8}{|c|}{ Total methane production (reactor + post-methanation) } \\
\hline & $1 \mathrm{kgVS}_{\text {feed }^{-1}}$ & n.a. & 293 & 334 & n.a. & 335 & 293 \\
\hline
\end{tabular}

n.a. not analysed, $\mathrm{P}_{\text {tot }}$ total phosphorus, $\mathrm{K}_{\text {tot }}$ total potassium. 
TABLE 13 Operational conditions, feedstock and digestate characteristics, and methane and post-methanation production in the CSTR experiments for brown knapweed and liquid cow manure (IV) in R1. Standard deviation is given after \pm .

\begin{tabular}{|c|c|c|c|c|c|}
\hline \multirow{2}{*}{\multicolumn{2}{|c|}{ Feeding regime }} & & \multirow{2}{*}{$\frac{\text { Cow manure }}{\mathrm{I}}$} & \multicolumn{2}{|c|}{$\begin{array}{c}\text { Cow manure and brown } \\
\text { knapweed }\end{array}$} \\
\hline & & & & II & III \\
\hline \multicolumn{2}{|c|}{ Share of crop } & $\% \mathrm{VS}$ & 0 & 20 & 50 \\
\hline \multicolumn{2}{|l|}{ OLR } & $\mathrm{kgVS} \mathrm{m}^{-3} \mathrm{~d}^{-1}$ & 2 & 2 & 2 \\
\hline \multicolumn{2}{|l|}{ HRT } & $\mathrm{d}$ & 23 & 28 & 35 \\
\hline \multicolumn{2}{|l|}{ Duration } & d & $0-42$ & $43-91$ & $98-140$ \\
\hline \multirow[t]{5}{*}{ Feedstock } & TS & $\%$ & 5.7 & 6.2 & 8.1 \\
\hline & VS & $\%$ & 4.7 & 5.3 & 7.1 \\
\hline & SCOD & $\mathrm{g} \mathrm{l}^{-1}$ & 13.1 & 10 & 8.8 \\
\hline & $\mathrm{NH}_{4}-\mathrm{N}$ & $\mathrm{g} \mathrm{l}^{-1}$ & 0.72 & 0.68 & 0.41 \\
\hline & $\mathrm{N}_{\text {tot }}$ & $\mathrm{g} \mathrm{l}^{-1}$ & 2.3 & 2.2 & 1.7 \\
\hline \multirow[t]{10}{*}{ Digestate } & TS & $\%$ & $4.8 \pm 0.2$ & $4.8 \pm 0.2$ & $4.7 \pm 0.1$ \\
\hline & VS & $\%$ & $3.7 \pm 0.3$ & $3.7 \pm 0.3$ & $3.7 \pm 0.0$ \\
\hline & SCOD & $\mathrm{g} \mathrm{l}^{-1}$ & $10.0 \pm 1.0$ & $8.7 \pm 0.9$ & $10.6 \pm 0.7$ \\
\hline & $\mathrm{NH}_{4}-\mathrm{N}$ & $\mathrm{g} \mathrm{l}^{-1}$ & $0.87 \pm 0.04$ & $0.77 \pm 0.05$ & $0.67 \pm 0.02$ \\
\hline & $\mathrm{N}_{\text {tot }}$ & $\mathrm{g} \mathrm{l}^{-1}$ & $2.5 \pm 0.1$ & $2.2 \pm 0.0$ & $2.0 \pm 0.1$ \\
\hline & $\mathrm{pH}$ & & $7.5 \pm 0.1$ & $7.5 \pm 0.03$ & $7.5 \pm 0.1$ \\
\hline & $\mathrm{VFA}_{\text {tot }}$ & $\mathrm{mg} \mathrm{l}^{-1}$ & $60 \pm 104$ & $57 \pm 9$ & $59 \pm 44$ \\
\hline & TS removal & $\%$ & 16 & 25 & 42 \\
\hline & VS removal & $\%$ & 21 & 33 & 48 \\
\hline & $\mathrm{CH}_{4}$ content & $t \quad \%$ & $57 \pm 2$ & $55 \pm 2$ & $49 \pm 3$ \\
\hline \multicolumn{6}{|c|}{ Calculated specific $\mathrm{CH}_{4}$ yield } \\
\hline & & $1 \mathrm{kgVS}^{-1}$ & 212 & 235 & 271 \\
\hline \multirow{2}{*}{\multicolumn{2}{|c|}{ Specific $\mathrm{CH}_{4}$ yield }} & $1 \mathrm{kgVS}-1$ & $193 \pm 2$ & $246 \pm 31$ & $254 \pm 9$ \\
\hline & & $1 \mathrm{kgWW}^{-1}$ & $9.0 \pm 0.1$ & $11.6 \pm 0.2$ & $17.7 \pm 0.2$ \\
\hline \multicolumn{2}{|c|}{$\begin{array}{l}\% \text { of total } \mathrm{CH}_{4} \text { potential } \\
\text { in substrates }\end{array}$} & $\%$ & 91 & 105 & 94 \\
\hline \multirow{3}{*}{\multicolumn{2}{|c|}{$\begin{array}{l}\text { Post-methanation } \\
\text { potential }\end{array}$}} & $1 \mathrm{CH}_{4} \mathrm{~kg} \mathrm{VS}_{\text {feed }^{-1}}$ & n.a. & $80 \pm 3$ & $61 \pm 7$ \\
\hline & & $1 \mathrm{CH}_{4} \mathrm{kgTS}_{\text {feed }^{-1}}$ & n.a. & 68 & 54 \\
\hline & & $1 \mathrm{CH}_{4} \mathrm{kgWW}^{-1}$ & n.a. & 5 & 4 \\
\hline \multicolumn{2}{|c|}{ Total methane production } & $1 \mathrm{CH}_{4} \mathrm{~kg} \mathrm{VS}_{\text {feed }^{-1}}$ & n.a. & 326 & 315 \\
\hline
\end{tabular}

n.a. not analysed 

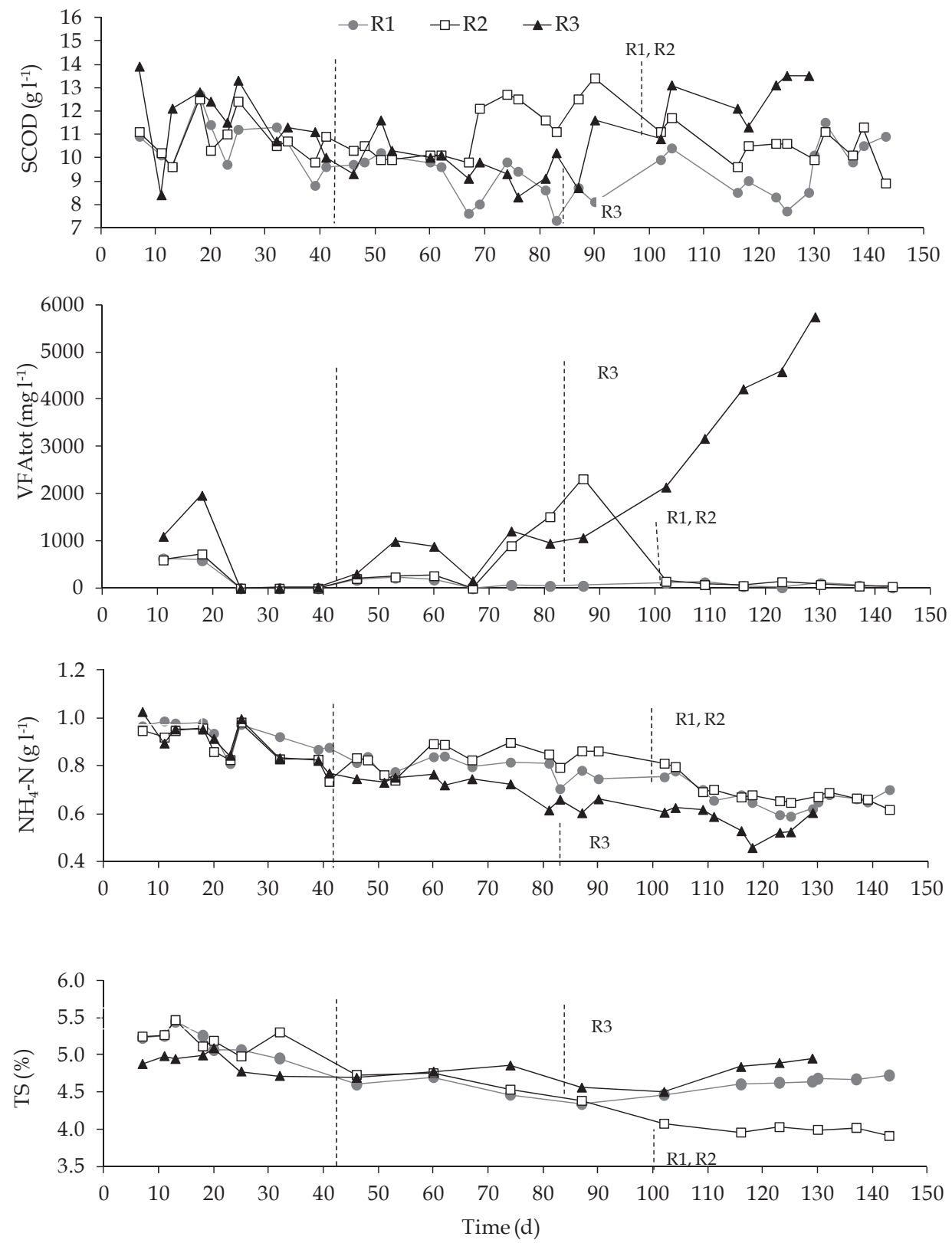

FIGURE 6 The characteristics (SCOD, VFA, $\mathrm{NH}_{4}-\mathrm{N}$, TS \% of digestate) of the digestate in anaerobic digestion of the manure alone, and with brown knapweed, at $20 \%$ and $50 \%$ of feed VS (R1), and the co-digestion of the cow manure with maize at $20 \%, 30 \%$ and $40 \%$ of the feedstock VS (R2), and at $50 \%, 60 \%$ and $67 \%$ of the feedstock VS (R3). The vertical dashed line indicates the change of the share of the crop in the feedstock (III, IV). 
The post-methanation potential of the digestate was determined in batch assays at $35^{\circ} \mathrm{C}$ for the digestates from brown knapweed at $20 \%$ and $50 \%$ of the feed (Table 13; IV), and from maize at 30, 40, 60 and $67 \%$ of the feed (Table 12; III). The post-methanation potentials were with brown knapweed at $611 \mathrm{kgVS}_{\text {feed }^{-1}}$ (20\% of brown knapweed) and $801 \mathrm{kgVS}_{\text {feed }}{ }^{-1}$ (50\% of brown knapweed), and with maize at $75-1401 \mathrm{kgVS}_{\text {feed }}{ }^{-1}$ (Table 12,13). The post-methanation potential of maize was the lowest (maize $40 \%, 75 \pm 11 \mathrm{kgVS}_{\text {feed }}{ }^{-1}$ ), when the methane production in the reactor was the highest $\left(259 \pm 61 \mathrm{kgVS}_{\text {feed }}{ }^{-1}\right)$ and when the methane production in the reactor was low (maize $67 \%, 153 \pm 46 \mathrm{lggVS}_{\text {feed }}{ }^{-1}$ ), the post-methanation potential was high $\left(1401 \mathrm{kgVS}_{\text {feed }}{ }^{-1}\right)$. The post-methanation potential decreased with the increase of HRT and the share of plant biomass in the feed. The post-methanation potentials were $25 \%$ and $19 \%$ of the total methane yields for the $20 \%$ and $50 \%$ of brown knapweed to feed, respectively (the methane yields of the reactor plus post-methanation experiments), and 23$48 \%$ of the total methane yields of maize.

The plant nutrients, trace elements and heavy metals were determined in the feeds (maize, liquid cow manure and inoculum) and in the digestates at the end of each feeding regime in the maize reactors (Table 14; III). Since the maize contained fewer plant nutrients and trace elements than the manure, the concentration of the plant nutrients and trace elements in the digestates decreased when the share of maize in the feed increased (Table 14). The concentrations of cadmium $(\mathrm{Cd})$, lead $(\mathrm{Pb})$ and arsenic $(\mathrm{As})$ were under the detection limit. 
TABLE 14 The concentration of plant nutrients (a) and heavy metals and trace elements (b) of the maize, liquid cow manure, inoculum and digestate from the CSTR experiment with maize (III) and biogas plant in Austria (maize silage and digestate $100 \%$ maize in feedstock) (Pobeheim et al. 2010).

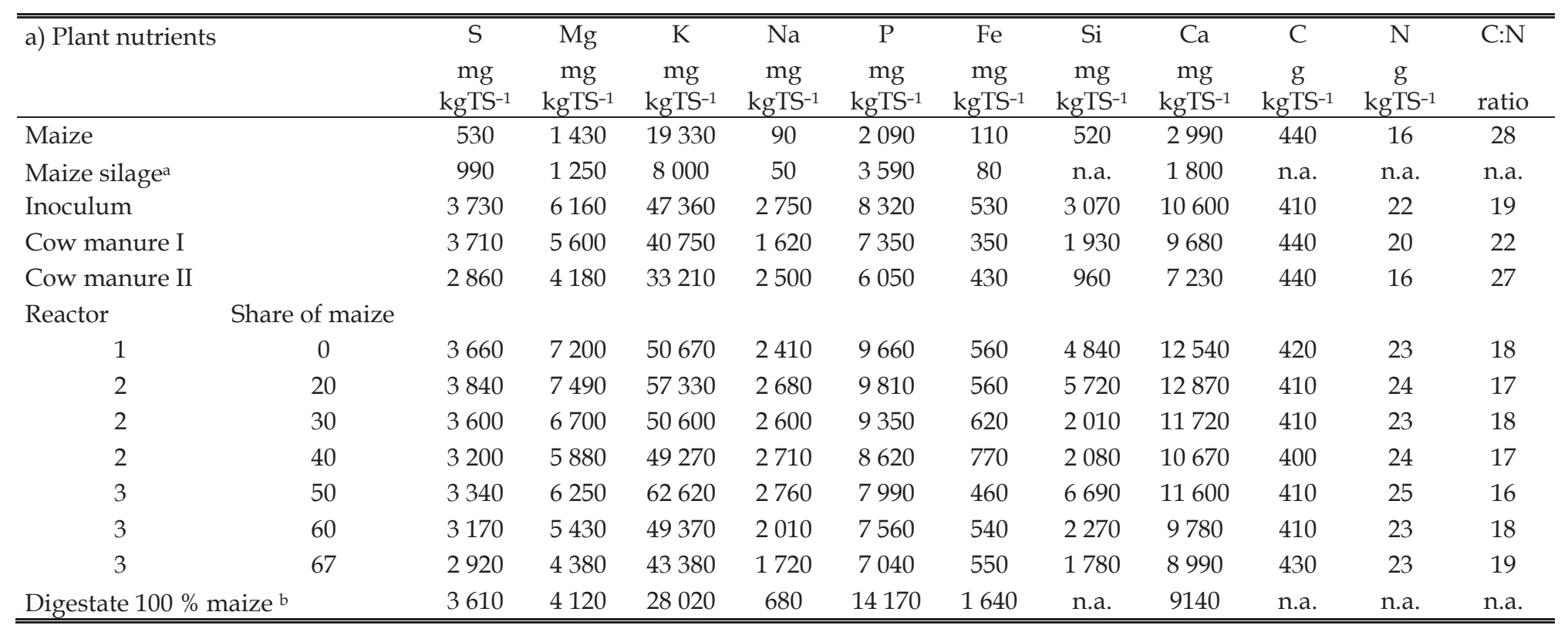


TABLE 14 Continues.

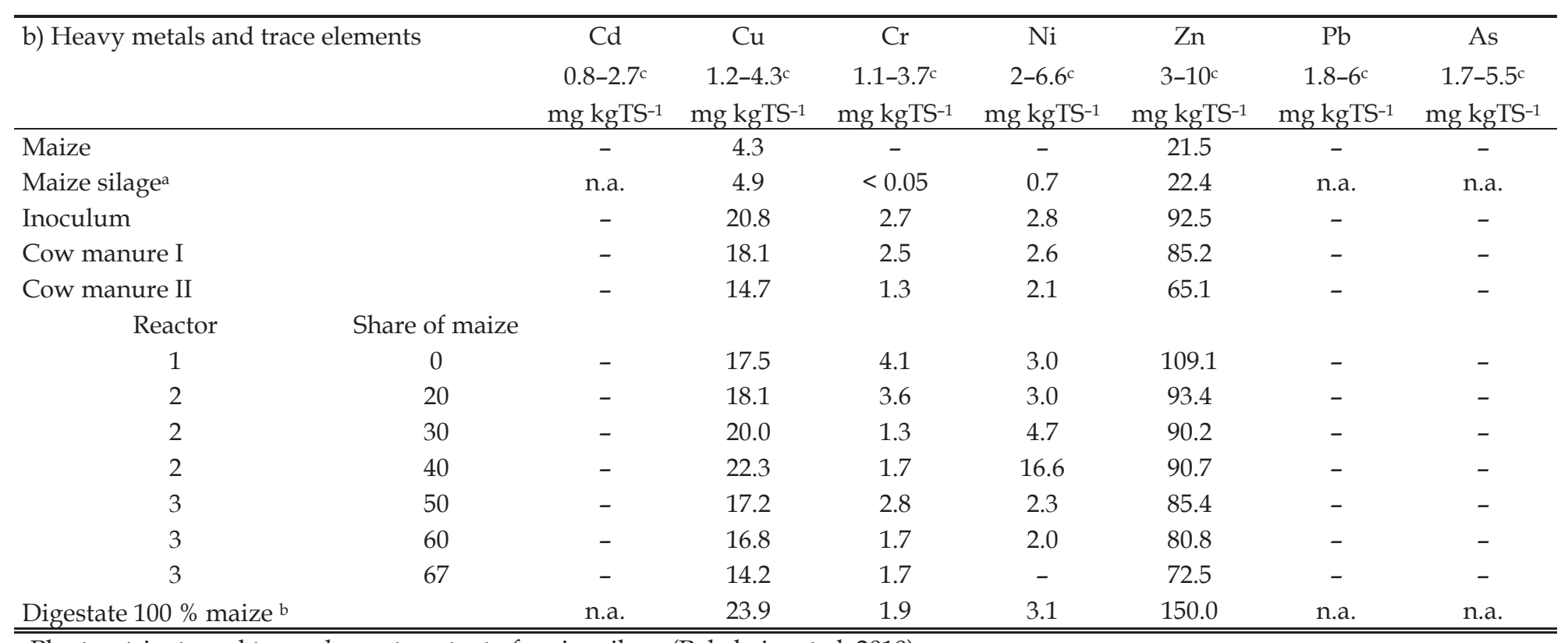

aPlant nutrients and trace element content of maize silage (Pobeheim et al. 2010).

bPlant nutrients and trace element contents of digestate from biogas plant in Austria, feedstock only maize silage (Pobeheim et al. 2010).

c detection limit - definition limit

$-=$ under detection limit

n.a $=$ not analysed 


\subsection{Energy balance of cultivation energy crops for biogas production}

The energy production and consumption for cultivation were calculated for grass, maize and brown knapweed, which produced 2200, 3900 and 3850 $\mathrm{m}^{3} \mathrm{CH}_{4} \mathrm{ha}^{-1}$, respectively, corresponding to a gross energy of $79900 \mathrm{MJ} \mathrm{ha}^{-1}$, $140400 \mathrm{MJ} \mathrm{ha}^{-1}$ and $138600 \mathrm{MJ} \mathrm{ha}^{-1}$, respectively (Table 15). The highest energy input was for manufacturing chemical fertilizers, from 2925 to $9945 \mathrm{MJ} \mathrm{ha}^{-1} \mathrm{a}^{-1}$; however, when using the digestate as fertilizer the energy input (loading and the transportation of digestate to the fields) of the fertilization was only 168-570 MJ $\mathrm{ha}^{-1} \mathrm{a}^{-1}$, depending on the cultivated energy crop (Table 15). When using the digestate for fertilization, the diesel fuel consumption for the maize cultivation and harvesting was over $50 \%$ (3 $\left.225 \mathrm{MJ} \mathrm{ha}^{-1} \mathrm{a}^{-1}\right)$ of the total energy input of the cultivation (sowing and ploughing every year). The energy inputs of diesel fuel for the cultivation and harvesting of perennials were $1290 \mathrm{MJ} \mathrm{ha}^{-1} \mathrm{a}^{-1}$ for brown knapweed and $2450 \mathrm{MJ} \mathrm{ha}^{-1} \mathrm{a}^{-1}$ for grass. The high diesel fuel consumption of grass cultivation was due to two harvests per growing season. Forage harvesting has the second highest diesel fuel consumption per hectare $\left(121 \mathrm{ha}^{-1}\right)$ after ploughing (24 1 ha-1 $^{-1}$ (Table 7).

TABLE 15 The energy consumption of cultivation inputs (MJ ha-1 $\mathrm{a}^{-1}$ ), total energy yield $\left(\mathrm{MJ} \mathrm{ha} \mathrm{a}^{-1} \mathrm{a}^{-1}\right)$ and the input/output -ratio of grass, maize and brown knapweed cultivation, with the fertilization of digestate or chemical fertilizer.

\begin{tabular}{|c|c|c|c|c|c|c|}
\hline \multirow[t]{2}{*}{ Energy input } & \multicolumn{2}{|c|}{ Grass } & \multicolumn{2}{|c|}{ Maize } & \multicolumn{2}{|c|}{ Brown knapweed } \\
\hline & Digestate & Chemical & Digestate & Chemical & Digestate & Chemical \\
\hline Cultivation, diesel & 960 & 762 & 2480 & 2082 & 544 & 445 \\
\hline Harvesting, diesel & 1490 & 1490 & 745 & 745 & 745 & 745 \\
\hline Liming & 400 & 400 & 400 & 400 & 400 & 400 \\
\hline Fertilization & 570 & 9945 & 302 & 5265 & 168 & 2925 \\
\hline Herbicide & 59 & 59 & 295 & 295 & 111 & 111 \\
\hline Preservative & 261 & 261 & 551 & 551 & 515 & 515 \\
\hline Seed & 60 & 60 & 240 & 240 & 30 & 30 \\
\hline Total input, MJ ha ${ }^{-1} \mathrm{a}^{-1}$ & 3802 & 12978 & 5014 & 9579 & 2512 & 5170 \\
\hline Total output MJ ha-1 $\mathrm{a}^{-1}$ & 79920 & 79920 & 140400 & 140400 & 138600 & 138600 \\
\hline input/output & $4.8 \%$ & $16.2 \%$ & $3.6 \%$ & $6.8 \%$ & $1.8 \%$ & $3.7 \%$ \\
\hline
\end{tabular}

The energy balance was calculated to compare the input/output relationship of every crop, and the different fertilization methods. The best (1.8 \%) input/output ratio was the cultivation of brown knapweed by using digestate as a fertilizer, and the worst $(16.2 \%)$ was when cultivating grass with chemical fertilizers (Table 15). The energy balance of using chemical fertilization in cultivation was almost doubled or even higher when compared to the use of digestate as a fertilizer. 


\section{DISCUSSION}

\subsection{Selecting energy crops for biogas production}

The results of the present study showed that cultivating energy crops can achieve high methane yields per hectare from grasses, maize and novel energy crops, like brown knapweed, in boreal conditions. The highest methane yields per hectare were achieved with maize cultivation (4 000-9 $\left.200 \mathrm{~m}^{3} \mathrm{ha}^{-1} \mathrm{a}^{-1}\right)$, and the second highest yields were in brown knapweed cultivation (2 700-6 $\left.100 \mathrm{~m}^{3} \mathrm{ha}^{-1} \mathrm{a}^{-1}\right)$ (Tables 16, 17). These two energy crops produce more methane than other recently tested feasible energy crops, such as grasses, which have been produced in boreal conditions (1 200-3 $600 \mathrm{~m}^{3} \mathrm{ha}^{-1} \mathrm{a}^{-1}$ ). To achieve high methane yields per hectare, the TS yield and specific methane yields of crops have to be high, or they have to compensate each other.

The specific methane yields of maize were the highest at $240-5001 \mathrm{kgVS}^{-1}$. Additionally, the TS yields per hectare were high (11-21 tTS ha-1) in southern Finland, and in the lower range in Central Finland (6.8-10 tTS ha-1). The specific methane yields of the novel energy crops were at the lower range at 170-380 1 $\mathrm{kgVS}^{-1}$, but the TS yields per hectare were high (7-23 tTS ha-1), which also resulted in high specific methane yields per hectare. The specific methane yields of the grasses were 250-390 $1 \mathrm{kgVS}^{-1}$, but the TS yields per hectare were low (6-13 tTS ha-1). In this study, the specific methane yields have been achieved in fresh crop material, which have been reported to be 2-8 \% higher than those achieved in ensilaged plant material, when storage losses (VS) have been considered (Pakarinen et al. 2008, Herrmann et al. 2011). During ensiling and storing, storage losses (VS) occur, which were mainly compensated by increased methane yield per kg VSadded (Table 16) (Herrmann et al. 2011). The high TS yield per hectare (r $=0.97)$ is more important than the specific methane yield, because high TS yields compensate better for the low specific methane yield to achieve high methane yields per hectare. In a previous study, the optimal harvest time for forage to biogas production was later than the normal dates for harvesting forage for milk 
production, since the lower specific methane yield was compensated for by higher TS yield per hectare (Fig. 4) (Gunnarson et al. 2008).

TABLE 16 Screening crops for biogas production among different characteristics and variables in this study and according to previous studies. References are given in parentheses.

\begin{tabular}{|c|c|c|c|c|}
\hline & Grasses & Maize & $\begin{array}{c}\text { Brown } \\
\text { knapweed }\end{array}$ & $\begin{array}{l}\text { Other novel } \\
\text { energy crops }\end{array}$ \\
\hline Methane yield, $\mathrm{m}^{3} \mathrm{ha}^{-1}$ & $1200-3600$ & $4000-9200$ & $2700-6100$ & $1200-4300$ \\
\hline $\begin{array}{l}\text { Specific methane yield, } \\
1 \mathrm{kgVS}^{-1}\end{array}$ & $250-390$ & $240-500$ & $180-360$ & $170-380$ \\
\hline TS yield, $\mathrm{t} \mathrm{ha}^{-1}$ & $6-13$ & $13-21$ & $15-23$ & $7-23$ \\
\hline Annual or perennial & perennial & annual & perennial & annual/perennia \\
\hline Sustainability $(1,2,3,4)$ & High & High & High & - \\
\hline $\begin{array}{l}\text { Input/output balance of } \\
\text { cultivation with digestate } \\
\text { (with chemical fertilizer) }\end{array}$ & $\begin{array}{c}4.3 \% \\
(16.3 \%)\end{array}$ & $\begin{array}{l}3.3 \% \\
(6.8 \%)\end{array}$ & $\begin{array}{l}1.7 \% \\
(3.8 \%)\end{array}$ & n.c. \\
\hline Cultivation zone & $\begin{array}{l}\text { Whole } \\
\text { Finland }\end{array}$ & $\begin{array}{l}\text { Southern } \\
\text { parts in } \\
\text { Finland }\end{array}$ & $\begin{array}{l}\text { Whole } \\
\text { Finland }\end{array}$ & - \\
\hline $\begin{array}{l}\text { Carbon accumulation }(5,6 \text {, } \\
7,8)\end{array}$ & High & Low & High & - \\
\hline Fertilization $(8,9)$ & High & High & Low & Variable \\
\hline Plant protection & Low & High & Moderate & Variable \\
\hline Biodiversity $(8,10)$ & High & - & - & - \\
\hline Frost resistance & High & Low & - & - \\
\hline Familiar to farmers (11) & Yes & No & No & No \\
\hline $\begin{array}{l}\text { Anaerobic digestion } \\
\text { process stability }(8,12,13 \text {, } \\
\text { 14) }\end{array}$ & Moderate & High & High & - \\
\hline $\begin{array}{l}\text { Storage mass losses (VS) } \\
(15,16)\end{array}$ & $2-5 \%$ & $4-8 \%$ & - & - \\
\hline
\end{tabular}

n.c. not calculated in this study

- No information

References: 1: Korres et al. (2010), 2: Gerin et al. (2008), 3: Felten et al. (2013), 4: Fazio \& Monti (2011), 5: Saggar et al. (1997), 6: Freibauer et al. (2004), 7: Jones \& Donelly (2004), 8: Prochnow et al. (2009), 9: MAVI (2009), 10: Khalsa et al. (2012), 11: Murphy \& Power (2009), 12: Lehtomäki et al. (2007), 13: Comino et al. (2010), 14: Thamsiriroj et al. (2012), 15: Pakarinen et al. (2008), 16: Herrmann et al. (2011).

When selecting energy crops for biogas production, the high methane yield per hectare is not the only thing to consider. The energy crops must also be easy to cultivate, harvest and store (mass (VS) losses during storing), tolerant to weeds, 
pests, diseases, drought and frost, and have a good winter hardiness (Table 16). They must be easy to feed into the biogas process and to ensure stable, feasible and efficient anaerobic digestion process. According to the results of this study, maize and brown knapweed have suitable feeds with co-digestion with liquid cow manure. The anaerobic digestion processes (OLR $2 \mathrm{kgVS} \mathrm{m}^{-3} \mathrm{~d}^{-1}$ ) were stable, and the highest methane yields were with maize at $2591 \mathrm{kgVS}^{-1}$ (40\% VS maize in the feed), and with brown knapweed at $2541 \mathrm{kgVS}^{-1}$ (50\% VS in the brown knapweed).

Maize can only be cultivated in southern Finland (cultivation zone I), where the high methane yields per hectare of this study have been achieved (Table 9). In Central Finland, maize cultivation suffered from the low heat summation and the short growing season in this study. Grasses can be cultivated throughout Finland, and are suitable sources of biomass for biogas production in boreal conditions (Table 16), when taking into account the familiarity for the farmers and yield security. The important factors to take into account, when choosing grass species for biogas production, are a high biomass yield per hectare, good digestibility and regrowth ability after the first harvest, like cocksfoot, timothy and tall fescue had in this study.

According to this study with novel energy crops, brown knapweed is the most promising novel energy crop for biogas production in northern conditions. The TS yield (15-23 tTS ha-1) and methane yield (almost $6100 \mathrm{~m}^{3} \mathrm{CH}_{4} \mathrm{ha}^{-1}$ ) per hectare are higher than previously considered grasses in biogas production (Table 17; I, IV). Brown knapweed appears to be flexible at harvest time, as the methane yield per hectare was the same in July and August, even though the specific methane yields decreased (from 330 to $2801 \mathrm{kgVS}^{-1}$ ) during the growing season while the TS yield increased (from 20.2 to $23.4 \mathrm{tTS} \mathrm{ha}^{-1}$ ) (Table 11). Brown knapweed is easy to cultivate and grows tall, and it starts to grow when the soil has thawed in the spring (Nissinen et al. 2010). Field trials with brown knapweed using different fertilization levels were conducted at the MTT Agrifood Research Finland in 2004-2009 (Nissinen et al. 2010).

Among other novel energy crops for biogas production, giant knotweed could be another novel crop for biogas production. Giant knotweed produced $4300 \mathrm{~m}^{3} \mathrm{CH}_{4} \mathrm{ha}^{-1}$, although the specific methane yield was low $\left(170 \mathrm{lkgVS}^{-1}\right)$ due to the late harvest time in this study (Table 11). Giant knotweed has been classified as an invasive weed, but two new cultivars for giant knotweed have been developed, which are not invasive, due to the fact that they have no stolons and no seeds. These two cultivars are IGNISCUM Candy ${ }^{\circledR}$ (for biogas production) and IGNISCUM Basic ${ }^{\circledR}$ (for incineration), which can be grown normally in the fields (Lebzien et al. 2012). IGNISCUM Candy ${ }^{\circledR}$ can be harvested 2-3 times during the growing season (Lebzien et al. 2012), which will increase the specific methane yield, when compared with the specific methane yields achieved in this study. The IGNISCUM species can only be sown from seedlings (micro-propagation), because the seeds of IGNISCUM (if they have any) do not germinate. IGNISCUM has been studied for its suitability for cultivation in Central Europe, and those experiments show that it is able to grow in poor nutrient soils (Veste et al. 2011). The TS yields per hectare, and the specific 
methane yield, can be considered to be almost equal to maize (Lebzien et al. 2012). Furthermore, it is advisable to cultivate poor and marginal lands where conventional cropping systems are not economically profitable, and the growing conditions are not favourable (Veste et al. 2011). Further study will be needed for cultivation management and growing possibilities on giant knotweed throughout Finland.

There are still many potential areas of investigation for the cultivation management of novel energy crops, including what kinds of soil preparation and sowing management should be done, and what are the right fertilization levels and optimal times to harvest. More research will be needed to improve cultivation management, energy balance and sustainability. However, according to this study, the high yielding novel energy crops for biogas production can be found in wild plants, like brown knapweed or weeds, like giant knotweed.

Using different food crops and energy crops for biogas production increases the diversity of the fields in the whole agro ecosystem. Cultivating wheat, barley or sugar beets for ethanol production, or rapeseed for biodiesel production, uses only a few crops for the cultivation of renewable energy sources, but in biogas production, different crops can be cultivated, including perennial grasses, maize, brown knapweed, giant knotweed, helianthus tuberosus, ley crops, and there is also a use for crop residues etc. In addition to designing a regional crop rotation, there can be an alternative to maize monoculture in Central Europe (Herrmann 2013), and cereal monoculture in boreal conditions. The cereals from crop rotation can be utilized as food production and perennial grasses for feed, or for biogas production. The crops and plants which are used for biogas production can also be perennial, with advantages for the soil conditions and structure, increasing the humus and carbon concentration of the soil (Saggar et al. 1997, Freibauer et al. 2004, Jones \& Donelly 2004, Prochnow et al. 2009) and improving the growing conditions for the next year's cereal production (Table 16). These issues must be considered when choosing the guidelines for the sustainable production of renewable energy (Table 16).

The potentially cultivated areas for biogas production consist of fallow land (fallows, nature management fields), which could be dedicated to biomass production without risking food supplies or feed production. The biomass cultivation for biogas production would also be a good alternative for the green manure of organic farming, which could be harvested for the anaerobic digestion process to produce biogas and after which the digestate can be used as a fertilizer in organic fields. The biodiversity of grasslands can increase with low mowing frequencies of only one or two cuts per growing season (Prochnow et al. 2009) (Table 16). On the other hand, grassland cultivation for biogas production may be advantageous to biodiversity when poor yielding fields are not abandoned (Prochnow et al. 2009). 
TABLE 17 The annual biomass yields and methane yields per hectare of selected energy crops reported in previous studies and in this study considering energy crops for biogas production in northern conditions. The energy crops have been distributed into three groups according to their methane yields per hectare.

\begin{tabular}{|c|c|c|c|}
\hline Energy crop & $\begin{array}{c}\text { Biomass } \\
\text { yield } \\
\text { tTS ha-1 }\end{array}$ & $\begin{array}{c}\text { Methane } \\
\text { yield } \\
\mathrm{m}^{3} \mathrm{ha}^{-1} \\
\end{array}$ & Reference \\
\hline \multicolumn{4}{|c|}{ Methane yield less than $3000 \mathrm{~m}^{3} \mathrm{CH}_{4}$ ha-1 } \\
\hline Lupine in Finland & $4-7$ & $1300-2300$ & Lehtomäki et al. (2008) \\
\hline Rhubarb in Finland & $2-4$ & $800-1700$ & Lehtomäki et al. (2008) \\
\hline Grasses in hill site in Austria & $4.2-6.4$ & $1000-1200$ & Amon et al. (2007a) \\
\hline Sorghum & 8.6 & 2500 & IV \\
\hline Hemp-agrimony & 6.5 & 1200 & IV \\
\hline Amaranth & 11.3 & 2700 & IV \\
\hline \multicolumn{4}{|c|}{ Methane yield $3000-5000 \mathrm{~m}^{3} \mathrm{CH}_{4}$ ha- $^{-1}$} \\
\hline Maize in Central Finland & 10 & $2100-3900$ & II \\
\hline Nettle in Finland & $6-10$ & $2200-3600$ & Lehtomäki et al. (2008) \\
\hline Hemp in Finland & 14 & 3066 & Pakarinen et al. (2011a) \\
\hline Faba bean in Finland & 10 & 3390 & Pakarinen et al. (2011a) \\
\hline Sunflower & n.r. & $2500-4600$ & Amon et al. (2007a) \\
\hline Grasses & $6-13$ & $1200-3600$ & I \\
\hline Reed canary grass in Finland & $9-10$ & $3800-4200$ & Lehtomäki et al. (2008) \\
\hline Timothy-clover grass in Finland & $8-11$ & $2900-4000$ & Lehtomäki et al. (2008) \\
\hline Grasses in valley site in Austria & n.r. & $2700-3500$ & Amon et al. (2007a) \\
\hline $\begin{array}{l}\text { Switchgrass in Canada under } \\
\text { cool humid climate }\end{array}$ & $11-12$ & $2900-3400$ & Massé et al. (2010) \\
\hline Giant goldenrod & 22.7 & 4000 & IV \\
\hline Japanese Millet & 13.9 & 4300 & IV \\
\hline Giant knotweed & $14-27$ & $2300-4300$ & IV \\
\hline \multicolumn{4}{|c|}{ Methane yield more than $5000 \mathrm{~m}^{3} \mathrm{CH}_{4}$ ha-1 $^{-1}$} \\
\hline Jerusalem arctichoke in Finland & $9-16$ & $3100-5400$ & Lehtomäki et al. (2008) \\
\hline Sorghum & $9.9-20.8$ & $4500-5800$ & $\begin{array}{l}\text { Mahmood \& Honermeier } \\
\text { (2012) }\end{array}$ \\
\hline Maize in southern Finland & $11-20$ & $4000-9200$ & III \\
\hline Maize in Finland & 15 & 5600 & Pakarinen et al. (2011a) \\
\hline Maize in Denmark & $11-18$ & $3600-6500$ & Bruni et al. (2010) \\
\hline Maize in Slovenia & $24-29$ & $6400-8900$ & Oslaj et al. (2010) \\
\hline Maize in Austria & $20-30$ & $8000-13000$ & Amon et al. (2007) \\
\hline Brown knapweed & $15-23$ & $2700-6100$ & IV \\
\hline
\end{tabular}

n.r. not reported 


\subsection{Methane production of energy crops in boreal conditions}

\subsubsection{TS yields per hectare}

In this study the TS yields of all maize varieties were high in Piikkiö (13-21 tTS ha $^{-1}$ ) (Table 9), and are in the same range as those reported for maize in Denmark (10.6-18.2 tTS ha-1 $^{-1}$ ) (Bruni et al. 2010) (Table 18). In Slovenia, the achieved TS yields were 24-29 tTS ha-1 (Oslaj et al. 2010), and in Austria they were 20-30 tTS ha $^{-1}$ (Amon et al. 2007a,b), which show the better growing conditions in these countries (higher heat summation and longer growing season) compared to Finland (Table 18). The TS yields of maize cultivated in Laukaa produced 6.8-10 tTS ha-1, which resulted from a lower fertilization level in Laukaa $\left(80 \mathrm{~kg} \mathrm{~N} \mathrm{ha}^{-1}\right)$, a shorter growing season, and lower heat summation than in Piikkiö (Table 3). The same reasons could have also caused the lower TS yields in Piikkiö in 2008, because the fertilization level was only $118 \mathrm{kgN} \mathrm{ha}^{-1}$, and the heat summation was $1045^{\circ} \mathrm{C}$ degree days, compared to the heat summation $\left(1085-1419{ }^{\circ} \mathrm{C}\right.$ degree days) and fertilization level (180 kgN ha-1) of 2007 (Table 3). According to the previous cultivation experiments, maize yielded an average of $6.4 \mathrm{tTS}^{\mathrm{ha}} \mathrm{h}^{-1}$ in Maaninka in Central Finland (Table 18) (Niiranen 2008), and 4-8 t TS ha-1 (nitrogen fertilization $100 \mathrm{kgN} \mathrm{ha}^{-1}$ ) in 2010 and 13-18 tTS ha-1 2011 in Central Finland (Saarinen et al. 2012). In previous studies, the variations in the growing seasons and fertilization levels affected the TS yields (Saarinen et al. 2012). In 2007, the heat summation was $10 \%$ higher in Finland than on average. However, the heat summation in 2008 was at the average level (Finnish meteorological institute 2007, 2008). Furthermore, the precipitation, soil type, fertilization and plant management affected maize cultivation and TS yields per hectare. A previous study from northern Germany (characterized by low temperature, high precipitation and clay soils) found that forage grass and cereals grown for the whole crop silage achieved yields in the same range as the maize, but at a higher yield security (Quakernack et al. 2012). The high TS yields per hectare in 2007 were also result of the longer growing time compared with the maize yield in 2008. The growing time for the maize varieties was approximately 100 days in Laukaa and 96-158 days in Piikkiö. The harvest time of the maize in this study was very early, compared with the harvest time for the other studies, when the growing time for maize was 130-195 days (Table 18) (Bruni et al. 2010, Amon et al. 2007b, Schittenhelm 2008).

The TS yields per hectare varied among the grass species and harvest year, from 6 to $13 \mathrm{tTS} \mathrm{ha}^{-1} \mathrm{a}^{-1}$ (Table 8). In this study the different fertilization rates (51$110 \mathrm{kgN} \mathrm{ha}^{-1}$ ) and harvest times were variable and they have an effect to the achieved TS yields. The TS yields of official variety trials (optimal fertilization, harvest times and cultivation methods) were 9-11 tTS ha-1 for timothy and tall fescue in Finland (Kangas et al. 2012). In the second harvest, tall fescue and cocksfoot showed higher TS yields (5.1 and $5.2 \mathrm{tTS} \mathrm{ha}^{-1}$ ) than either timothy (2.7 tTS ha-1) or reed canary grass (2.9 and 3.4 tTS ha- $\left.^{-1}\right)$. In general, tall fescue and cocksfoot have better regrowth ability after the $1^{\text {st }}$ harvest than timothy and reed 
canary grass (Sheldrik 2000). Good regrowth ability means higher TS yields from the $2^{\text {nd }}$ and $3^{\text {rd }}$ harvest. High TS yields can be achieved from grasslands, when grass mixtures are cultivated because the growth rates of the different grass species compensate for each other. In the second harvest year (2006) the growing season had very low rainfall and the second harvest failed because of no growth. This led to low annual methane yields per hectare in Saarijärvi. Reed canary grass achieved high TS yields when harvested after winter and it has been found to be more suitable for combustion than other perennial herbaceous grasses (Pahkala \& Pihala 2000).

In the early growing season, when growing conditions are at their best, the nitrogen uptake of the grasses was even higher than the amount supplied by the fertilizer (Hakkola 1998). Therefore, grasses have a high nitrogen efficiency. Nitrogen fertilization increases the TS yields of grasslands and it has an effect on the species composition (Griffin et al. 2002). The digestate produced by anaerobic digestion is suitable for fertilizing grassland. The spreading of digestates in spring has given the best results to the efficient use of nitrogen for grass dry matter production, and for reducing environmental risks (Matsunaka et al. 2006). The best results of using digestate as fertilizer have been achieved when the digestate was used as a local fertilizing (digestate located below the ground) (Kapuinen et al. 2008).

In this study the highest annual TS yields among novel energy crops were for brown knapweed at 20.2-23.4 $\mathrm{tTS} \mathrm{ha}^{-1}$ (B07, C07) and giant goldenrod at 22.7 tTS ha-1 (Table 11), which were about two-fold higher than the grass yields in Finland, which were 6-13 tTS ha-1 (Table 17; I). The TS yields of brown knapweed increased from the first harvest (A08) to the third harvest (C08) in 2008, while in the fourth (last) harvest, the TS yield (10.9 tTS ha-1) decreased because of the defoliation of leaves. Brown knapweed produced almost 9 tTS ha-1 in northern Finland (Rovaniemi) and up to 20-24 tTS ha-1 in Central Finland (Laukaa) (Nissinen et al. 2010), indicating the potential of high TS yields in northern conditions. Sorghum is a $\mathrm{C}_{4}$ crop, which produces higher TS yields (10-

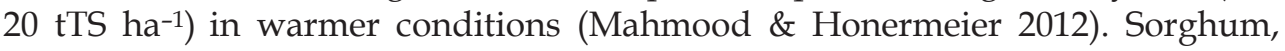
Japanese millet and amaranth are $\mathrm{C}_{4}$ plants which grow best in the tropics and subtropics, but the TS yields (8.5-13.9 tTS ha-1) of these plants in this study was quite high when compared with the yield of grasses in Finland (Table 17; I). Additionally the $\mathrm{N}_{\text {tot }}$ content of brown knapweed (A08) was high at $19.8 \mathrm{mg}$ gTS $^{-1}$ (Table 11), and brown knapweed had taken $\mathrm{N}_{\text {tot }}$ of $186 \mathrm{~kg} \mathrm{ha}^{-1}$. The efficiency of nitrogen use for brown knapweed was high because it received only $30 \mathrm{kgN} \mathrm{ha}^{-1}$

of nitrogen fertilizer (Table 4). The high efficiency of nitrogen use is typical for weeds and wild plants (Nissinen et al. 2010).

\subsubsection{Specific methane yield}

The maize varieties produced the highest specific methane yields (240-500 1 $\mathrm{kgVS}^{-1}$ ) in this study, and are comparable with other reports in the relevant literature (Table 18) (Amon et al. 2007a,b, Shittenhelm 2008, Tatah et al. 2008, Bruni et al. 2010, Oslaj et al. 2010, Pakarinen et al. 2011b, Gao et al. 2012). There 
were no differences in the specific methane yields of the harvest and sowing time (Table 9), whereas the specific methane yields have been found to increase towards maturity (Schittenhelm 2008) (Table 18). In contrast, Amon et al. (2007b) found a general decrease in the specific methane yields towards maturity. The biomass yield increases when the plants mature, but the direction of the specific methane yield is not obvious. According to Amon et al. (2007b), the maize used in their study indicates that the specific methane yields were strongly dependent on maize composition. Nutrients, crude protein, crude fat, cellulose, and hemicellulose proved to have an influence on methane production (Amon et al. 2007a,b, Oslaj et al. 2010), and the biggest increase in the specific methane yield was in relation to the crude protein and crude fat (Amon et al. 2007a,b). In another study, the composition of maize had no any influence on the specific methane yields (Schittenhelm 2008). According to Schittenhelm (2008), the energy maize prototypes, Doge and Mikado, in spite of a significantly greater plant height and higher cellulose and lignin concentration, did not produce lower specific methane yields than the shorter maize hybrids. This may be attributable to the fact that the complexity of the bonding within the cell-wall carbohydrate complex increases towards physiological maturity (Morrison et al. 1998), and that the stover cell-wall fraction of immature energy maize is more easily accessible to microbial fermentation (Schittenhelm 2008).

The various maize plant parts have different specific methane yields, which were the highest in cobs, with an average of $370 \mathrm{l} \mathrm{kgVS}^{-1}$. Furthermore, the specific methane yields of the cobs increased when the maize varieties matured, and the photosynthetic products were transported to the cobs. The cobs are sinks where the photosynthetic products (proteins, fatty acids, starch) and nutrients will be transported from the source organs (stems and leaves). The cobs produce more methane than other plant parts because they contain higher concentrations of easily degradable components, such as starch, fatty acids and protein (Ettle \& Schwarz 2003). The leaves produced an average of $3101 \mathrm{kgVS}^{-1}$, and the stems produced an average of $3401 \mathrm{kgVS}^{-1}$ (Table 10). The results are at the same level as those previously reported for specific methane yields (corn cob mix 3161 $\mathrm{kgVS}^{-1}$, corns only $3091 \mathrm{kgVS}^{-1}$, maize without corn $2741 \mathrm{kgVS}^{-1}$ ) (Amon et al. 2007b). The digestibility and specific methane yields of the stems and leaves decrease when maize matures, because of not easily degradable components such as lignin, neutral detergent fibre (NDF), acid detergent fibre (ADF) and cellulose concentration increase (Darby \& Lauer 2002, Ettle \& Schwarz 2003, Kruse et al. 2008). Lower cell wall concentrations were consistently reported for the hot growing season, compared to the cool growing conditions (Kruse et al. 2008). Stover (includes stems and leaves) fibre content usually continues to increase after silking. This is caused by an accumulation of cell wall material and remobilization of non-structural carbohydrates into the growing cobs (Kruse et al. 2008, Herrmann \& Rath 2012). Nevertheless, the whole-crop-fibre content decreases as a result of starch accumulation in the cob, which overcompensates for the rise in the cell wall content of the stover (Kruse et al. 2008). The digestibility of the stems and leaves has been studied previously in relation to corn maize residues being used for silage (Tolera et al. 1999). Varieties with 
better stover digestibility have been developed, which is good for maize varieties being used in biogas production.

Whole maize crops produced more methane in the batch assays than the stems, leaves and cobs alone, and the specific methane yields per hectare were higher than the methane yields per hectare calculated for the various plant parts. Similar results were achieved earlier from the maize without cobs, corn cob mix and whole maize crops (Amon et al. 2007b). A whole maize crop contains nutrients that are suitable for anaerobic microbes, and the concentration and ratio of nutrients can likely be more conducive to methane production, as in an improved $\mathrm{C} / \mathrm{N}$-ratio. The $\mathrm{C} / \mathrm{N}$ ratio of maize (variety Valdez) was 28 (Table 14), which is optimum for the anaerobic digestion process. This means that, when maize is used for biogas production, the whole maize crop should also be harvested for biogas production, because the specific methane yields per hectare are consequently the highest. The methane yield per hectare decreased in the later harvest of stems and leaves alike. Moreover, the methane yields per hectare of maize without the cobs decreased when the maize was maturing (Amon et al. 2007b).

The specific methane yields of the grass species (250-390 $\left.1 \mathrm{kgVS}^{-1}\right)$ obtained in this study were within the same range as those previously reported for grasses (Kaparaju et al. 2002, Mähnert et al. 2005, Lehtomäki et al. 2008). In this study, the specific methane yields of grasses decreased from the $1^{\text {st }}$ to $2^{\text {nd }}$ harvest, as in an earlier study (Amon et al. 2007a, Massé et al. 2010). With the increase of maturity, the proportion of the cell wall components of the grasses (cellulose, hemicellulose and lignin) increases, whereas the proportion of cell contents decreases (Bruinenberg et al. 2002, McEniry \& O'Kiely 2013) (Fig. 3). When the spikes and panicles begin to appear, the TS yield is almost at its maximum, digestibility is high, and the ratio of leaves to stems is high. The leaves of grasses are more digestible than the stems (Gilliland 1997, Bruinenberg et al. 2002), which contain little protein and have low digestibility (Nissinen 2004). In the generative growth stage, the TS yield increases to over $200 \mathrm{~kg} \mathrm{TS} \mathrm{ha}^{-1}$ per day, however, digestibility (Ito et al. 1997), and the amount of raw protein, decrease by $0.5-1.0$ percentage units per day (Nissinen 2004) (Fig. 4). Postponing the first harvest may increase the methane yield per hectare due to the higher TS yield (McEniry \& O'Kiely 2013). Generally, however, the specific methane yield falls when grasses mature due to the increase in lignin and neutral detergent fibre content (McEniry \& O'Kiely 2013). After the first harvest, the regrowth of grasses is typically leafier, containing less cell wall carbohydrate, however it is less digestible than the corresponding primary growth of grass (Huhtanen et al. 2006, Kuoppala et al. 2008). The lower digestibility of the regrowth grass silage is related to the higher proportion of indigestible NDF in the cell wall, compared with the grass silage harvested from the generative growth stage (Huhtanen et al. 2006). The efficiency of anaerobic digestion can be improved in mixed feedstock, such as the different grass species with legumes, because the neutral detergent fibre content of grasses is usually higher than that of legumes. Also, increasing the proportion of legume species in the mixture, the leaf to stem ratio increases, and the specific methane yields can increase (Nizami et al. 2009, Kandel et al. 
2013). The low specific methane yields of reed canary grass are apparently due to low digestibility, which is the reason why reed canary grass is not a good forage species (Ito et al. 1997, Geber 2002). In the present study, the TS yield and methane yield of reed canary grass decreased during the harvest year. Reed canary grass has also been reported to be less tolerant of frequent cutting than other grasses (Ito et al. 1997).

The specific methane yields of novel energy crops were in the lower or same range as those usually used for biogas production (grasses and maize). The high specific methane yields are due to the fact that certain crops (grasses and maize) have been bred for food and feed, having good digestibility. In this study, the specific methane yield of sunflower $\left(3801 \mathrm{kgVS}^{-1}\right)$ was in the upper range as achieved in the late harvest time 154-335 $1 \mathrm{kgVS}^{-1}$ in Austria (Amon et al. 2007a) and with sorghum (330 $\left.1 \mathrm{kgVS}^{-1}\right)$, in the same range at 230-380 $1 \mathrm{kgVS}^{-1}$ in Germany (Mahmood \& Honermeier 2012). The specific methane yield of wild plant, brown knapweed (on average $2901 \mathrm{kgVS}^{-1}$ ), and weed, giant knotweed $\left(1701 \mathrm{kgVS}^{-1}\right)$, were in the same range as previously reported (104-302 $\left.1 \mathrm{kgVS}^{-1}\right)$ (Triolo et al. 2012). Triolo et al. (2012), who studied wild plants, crops, lawn, and hedge and wood cuttings, found that the specific methane yields of wild plants varied more than the specific methane yields of crops. The high variation in the specific methane yields of the wild plants was due to the large and variable amount of lignocellulose in wild plants (Triolo et al. 2012).

The novel energy crops in this study included the different species of plants (annual or perennial and monocotyledon or dicotyledon), and that is why the specific methane yields varied from species to species. The large variable of specific methane yields was also the result of the growing stage (vegetative or generative) at harvest time. The decrease of the specific methane yield of brown knapweed during the growing season was due to the defoliation of the leaves, and the stems lignified. The specific methane yields of maize (II) and grass (I) have also decreased during the growing season (McEniry \& O'Kiely 2013).

The specific methane yield of giant knotweed was low when compared with previous studies (170-260 $1 \mathrm{kgVS}^{-1}$ ) (Salter 2007, Lehtomäki et al. 2008), which apparently was because it was harvested during the late maturing growth stage, when its digestibility had decreased. Giant knotweed can be harvested two to three times during the growing season, because it produces new stems and leaves after every harvest (Lebzien et al. 2012). Harvesting giant knotweed at an earlier growth stage will see an increase in the specific methane yield, because the plant is more immature than in this study, when giant knotweed was harvested at the end of August. The harvest intensity and harvest time of giant knotweed must be studied more carefully so that higher specific methane yields, TS yields and methane yields per hectare can be achieved in boreal conditions.

\subsubsection{The methane yield per hectare}

The results of the present study show that maize can be cultivated in boreal conditions for biogas production in southern Finland. The methane yields were lower in 2008, apparently due to a shorter growing season, lower heat 
summation and lower fertilization rate than in 2007, and, therefore, the TS yields were also lower. The methane yields achieved in Piikkiö are in the same range as those in previous studies: $5500-6500 \mathrm{~m}^{3} \mathrm{ha}^{-1}$ in Denmark (Bruni et al. 2010) and $6400-8900 \mathrm{~m}^{3} \mathrm{ha}^{-1}$ in Slovenia (Oslaj et al. 2010) (Table 18). The highest maize methane yields 7500-10200 $\mathrm{m}^{3}$ ha-1 $^{-1}$ were reported regarding maize varieties harvested at "wax ripeness" in Austria (Amon et al. 2007a,b). Moreover, high methane yields have also been achieved in Germany (7 400-9 $400 \mathrm{~m}^{3} \mathrm{ha}^{-1}$ ) (Schittenhelm 2008) (Table 18). The high methane yields per hectare (4 000-9 000 $\mathrm{m}^{3} \mathrm{ha}^{-1}$ ) in Finland are due to both the high specific methane yields and the high TS yield per hectare. The significance of the maize variety is not very important in boreal conditions; however variety should be tolerance for cool conditions, because the later maturing maize varieties do not have time to mature due to the shorter growing season. Maize can be harvested to the biogas process at the early maturing stage, when the cobs are not even appeared. Naturally, the significance of the variety is more important in the Central Finland than the southern parts of Finland, where the growing season is longer.

The methane yields per hectare increased when the maize was harvested at a later harvest time (A2) due to the higher TS yields per hectare (Table 9). In Denmark, the methane yield per hectare increased, on average, from 3797 to $6314 \mathrm{~m}^{3} \mathrm{ha}^{-1}$ in late ripening varieties in later harvest (Bruni et al. 2010), but in our study, the colder weather limited the growth of maize, and the methane yield per hectare did not increase as much (only $900 \mathrm{~m}^{3} \mathrm{CH}_{4} \mathrm{ha}^{-1}$ ) in the autumn. Moreover, in other studies, the methane yields per hectare increased when maize was harvested later (Amon et al. 2007a,b, Schittenhelm 2008). The optimum harvest time for maize grown for biogas production is presently under investigation (Amon et al. 2007a,b, Kruse et al. 2008).

Grasses are a suitable source of biomass for biogas production in boreal conditions, producing methane yields that ranged from 1200 to $3600 \mathrm{~m}^{3} \mathrm{ha}^{-1} \mathrm{a}^{-1}$ in different harvesting years (Table 17). Over $3000 \mathrm{~m}^{3} \mathrm{ha}^{-1}$ could be achieved when the TS yields are over $9 \mathrm{tTS} \mathrm{ha}^{-1}$. This is possible if the both grass harvests are fertilized and harvested, like result in official variety trials have shown when the TS yields of grasses can be 9-11 tTS ha-1 (Kangas et al. 2012). No difference was observed in the methane yields per hectare between tall fescue, cocksfoot and timothy in this study. The methane production of grasses has been 800-3 500 $\mathrm{m}^{3} \mathrm{ha}^{-1} \mathrm{a}^{-1}$, depending on the management intensity and the cropping system used in the Alpine region in Austria (Amon et al. 2007a), and in the Ardenne uplands in Belgium (Gerin et al. 2008). According to Kandel et al. (2013), the maximum methane yield per hectare $\left(5430 \mathrm{~m}^{3} \mathrm{ha}^{-1} \mathrm{a}^{-1}\right)$ of reed canary grass can be achieved with two harvests per growing season: the first in the summer and the second in the autumn. Furthermore, the methane yields per hectare were also increased when the amount of different plant species increased in the field (Khalsa et al. 2012).

The highest methane yields per hectare of nine novel energy crops were achieved in this study with brown knapweed $\left(6100 \mathrm{~m}^{3} \mathrm{CH}_{4} \mathrm{ha}^{-1} \mathrm{a}^{-1}\right)$ harvested in July (B08) and August (C08) in 2008 (Table 11), which was at the same level as the methane yield of maize in Denmark (3 600-6 $500 \mathrm{~m}^{3} \mathrm{ha}^{-1} \mathrm{a}^{-1}$ ) (Bruni et al. 
TABLE 18 The maize cultivation, growing time, TS content, TS yield, specific methane yield and methane yield per hectare in previous studies.

\begin{tabular}{|c|c|c|c|c|c|c|c|}
\hline Maize variety & Year & $\begin{array}{l}\text { Maturity } \\
\text { index }\end{array}$ & $\begin{array}{c}\text { Growing } \\
\text { time } \\
\mathrm{d} \\
\end{array}$ & $\begin{array}{l}\text { TS } \\
\% \\
\end{array}$ & $\begin{array}{c}\text { TS } \\
\text { yield } \\
\text { t ha-1 }\end{array}$ & $\begin{array}{l}\text { Specific } \\
\text { methane } \\
\text { yield } \\
1 \mathrm{kgVS}^{-1}\end{array}$ & $\begin{array}{c}\text { Methane } \\
\text { yield } \\
\mathrm{m}^{3} \mathrm{ha}^{-1}\end{array}$ \\
\hline \multicolumn{8}{|c|}{ Maaninka, Central Finland (Niiranen 2008) } \\
\hline Rosalie & 2004 & - & - & - & 4.4 & - & - \\
\hline Cerruti & 2005 & 210 & - & - & 10 & - & - \\
\hline Cerruti & 2006 & 210 & - & - & 5.3 & - & - \\
\hline Cerruti & 2007 & 210 & 110 & - & 7.7 & - & - \\
\hline Amadeo & 2008 & 220 & - & - & 4.7 & - & - \\
\hline \multicolumn{8}{|c|}{ Maaninka, Central Finland (Saarinen et al. 2012) } \\
\hline Kreel & 2010 & - & - & - & 9.6 & - & - \\
\hline Kreel & 2011 & - & - & - & 20.7 & - & - \\
\hline \multicolumn{8}{|c|}{ Ruukki, Central Finland (Saarinen et al. 2012) } \\
\hline Kreel & 2010 & - & - & - & 9.2 & - & - \\
\hline Kreel & 2011 & - & - & - & 17.0 & - & - \\
\hline \multicolumn{8}{|c|}{ Ylistaro, Central Finland (Saarinen et al. 2012) } \\
\hline Kreel & 2010 & - & - & - & 5.1 & - & - \\
\hline Kreel & 2011 & - & - & - & 14.8 & - & - \\
\hline \multicolumn{8}{|c|}{ Braunschweigh, North Germany (Schittenhelm 2008) } \\
\hline \multirow[t]{5}{*}{ Gavott } & 2004 & 250 & 96 & 14 & - & 300 & - \\
\hline & & & 124 & 23 & - & 287 & - \\
\hline & & & 153 & 32 & - & 340 & 7500 \\
\hline & & & 180 & 35 & - & 330 & - \\
\hline & & & 194 & 39 & - & - & - \\
\hline \multirow[t]{5}{*}{ Mikado } & 2004 & 500 & 96 & 11 & - & 310 & - \\
\hline & & & 124 & 18 & - & 335 & - \\
\hline & & & 153 & 21 & - & 320 & - \\
\hline & & & 180 & 24 & - & 350 & 7700 \\
\hline & & & 194 & 35 & - & - & - \\
\hline \multirow[t]{5}{*}{ Doge } & 2004 & 700 & 96 & 11 & - & 330 & - \\
\hline & & & 124 & 17 & - & 295 & - \\
\hline & & & 153 & 19 & - & 360 & - \\
\hline & & & 180 & 22 & - & 419 & 9400 \\
\hline & & & 194 & 26 & - & - & - \\
\hline \multicolumn{8}{|c|}{ Grenaa, Denmark (Bruni et al. 2010) } \\
\hline \multirow[t]{3}{*}{ Banguy } & 2006 & late ripening & 116 & 23 & 10.6 & 360 & $3600 a$ \\
\hline & & & 137 & 32 & 15.5 & 370 & $5500^{a}$ \\
\hline & & & 157 & 39 & 16.7 & 380 & $6100^{a}$ \\
\hline \multirow[t]{3}{*}{ Fantastic } & 2006 & late ripening & 116 & 22 & 11.4 & 340 & $3700^{a}$ \\
\hline & & & 137 & 29 & 16 & 390 & $6100 \mathrm{a}$ \\
\hline & & & 157 & 39 & 17.8 & 380 & $6600^{a}$ \\
\hline \multirow[t]{3}{*}{ Graphic } & 2006 & late ripening & 116 & 22 & 11.5 & 370 & $4100^{a}$ \\
\hline & & & 137 & 29 & 16.3 & 380 & $6000^{a}$ \\
\hline & & & 157 & 38 & 18.2 & 360 & $6300^{a}$ \\
\hline
\end{tabular}


TABLE 18 Continues.

\begin{tabular}{|c|c|c|c|c|c|c|c|}
\hline Maize variety & Year & FAO & $\begin{array}{l}\text { Growing } \\
\text { time } \\
\text { d }\end{array}$ & $\begin{array}{c}\text { TS } \\
\% \\
\end{array}$ & $\begin{array}{c}\text { TS } \\
\text { yield } \\
\text { t ha-1 }^{-1} \\
\end{array}$ & $\begin{array}{l}\text { Specific } \\
\text { methane } \\
1 \mathrm{kgVS}^{-1}\end{array}$ & $\begin{array}{c}\text { Methane } \\
\text { yield } \\
\mathrm{m}^{3} \text { ha }^{-1}\end{array}$ \\
\hline \multicolumn{8}{|c|}{ Slovenia (Oslaj et al. 2010) } \\
\hline PR38F70 & 2007 & $300-400$ & - & - & 26.8 & 310 & 7600 \\
\hline PR38H20 & 2007 & $300-400$ & - & - & 26.1 & 300 & 7100 \\
\hline NKTHERMO & 2007 & $300-400$ & - & - & 27.8 & 250 & 7000 \\
\hline PR37D25 & 2007 & $400-500$ & - & - & 27.7 & 310 & 7600 \\
\hline PR73F73 & 2007 & $400-500$ & - & - & 26.1 & 350 & 8100 \\
\hline PR37M34 & 2007 & $400-500$ & - & - & 29.1 & 340 & 8900 \\
\hline TIXXUS & 2007 & $500-600$ & - & - & 26.4 & 310 & 7400 \\
\hline CODISTAR & 2007 & $500-600$ & - & - & 28.7 & 330 & 8600 \\
\hline PR34N43 & 2007 & $500-600$ & - & - & 24.2 & 300 & 6400 \\
\hline \multicolumn{8}{|c|}{ Beijing, China (Gao et al. 2012) } \\
\hline Milk ripeness & - & - & 79 & - & $8.6^{\mathrm{ab}}$ & 250 & 2200 \\
\hline Wax ripeness & - & - & 97 & - & $14.9 \mathrm{ab}$ & 300 & 4500 \\
\hline Full ripeness & - & - & 106 & - & $24.4^{\mathrm{ab}}$ & 270 & 6500 \\
\hline
\end{tabular}

aCalculated from values in the article

btVS ha-1

- not reported

2010) and in southern Finland (4 000-9 $200 \mathrm{~m}^{3} \mathrm{ha}^{-1} \mathrm{a}^{-1}$ ) (Table 11; II). The methane yields of brown knapweed, Japanese millet, giant knotweed and giant goldenrod were over $4000 \mathrm{~m}^{3} \mathrm{ha}^{-1}$, which was high when compared with the methane yields of grasses (1 200-3 $\left.600 \mathrm{~m}^{3} \mathrm{ha}^{-1} \mathrm{a}^{-1}\right)$ (Table 17). When comparing the methane yield of brown knapweed to the other non-food plants (lupine, nettle, rhubarb, hemp), shown in Table 17, the methane yield of brown knapweed was almost double per hectare. The methane yields per hectare of giant knotweed are in the same range as reported previously, for example, for timothy-clover grasses (2 800-3 $\left.800 \mathrm{~m}^{3} \mathrm{ha}^{-1}\right)$ (Lehtomäki et al. 2008) and hemp (3 $100 \mathrm{~m}^{3} \mathrm{ha}^{-1}$ ) (Pakarinen et al. 2011a) (Table 17).

\subsection{Co-digestion of maize or brown knapweed with liquid cow manure in the CSTR process}

\subsubsection{Methane yields and post-methanation potential}

The present results indicate that anaerobic digestion of liquid cow manure and maize or brown knapweed in CSTRs is feasible at lower than $60 \%$ VS of maize and $50 \%$ VS of brown knapweed in the feed. The highest methane yields of 259 and $2541 \mathrm{kgVS}^{-1}$ in the co-digestion of liquid cow manure with maize (40\% of feed) and brown knapweed (50\% of feed), respectively, corresponded to 94-95 $\%$ of the specific methane yields in the feedstock as determined by the batch 
assays. When the share of brown knapweed was $20 \%$ of the feed VS the methane yield was $105 \%$ of the calculated methane yield of the feedstock (Table 13). This indicates that there have been some synergistic effects of the co-digestion, which could be due to a better $\mathrm{C} / \mathrm{N}$ ratio and nutrient composition. To the best of our knowledge, the CSTR experiments have not been conducted previously with any wild plant, and according to the results of this co-digestion experiment, brown knapweed is suitable for biogas production because of the high methane yield from the reactor, high degradation of VS and the stable concentrations of VFA, SCOD and $\mathrm{pH}$ (Fig. 6, Table 13).

The HRT of this study was 23 days for cow manure, 28 and 35 days for brown knapweed (R1) and 25-30 days in two maize reactors (R2 and R3). This study, as well as other recent studies (Lehtomäki et al. 2007, Comino et al. 2010), suggests that mesophilic biogas reactors can be operated with an HRT of 30 days, which is shorter than that used in full-scale biogas plants. The typical HRT of biogas plants which treat energy crops together with manure is between 60 and 90 days, and the OLR is from 2 to $4 \mathrm{kgVS} \mathrm{m}^{-3} \mathrm{~d}^{-1}$ (Weiland 2006, 2010). The OLR of the reactors in this study was $2-3 \mathrm{~kg} \mathrm{VS} \mathrm{m}^{-3} \mathrm{~d}^{-1}$, and the share of maize used in the feedstock was similar to or lower than that found in previous studies of the same nature (Table 19) (Cornell et al. 2008, 2011, Lindorfer et al. 2008). The highest single OLR $\left(6 \mathrm{kgVS} \mathrm{m}^{-3} \mathrm{~d}^{-1}\right)$ was reported in laboratory scale CSTR with a maize share of $50 \%$, providing a methane yield of $2101 \mathrm{kgVS}^{-1}$ (Table 19). The OLR, however, was not optimal because of a decrease in the methane yield (Cornell et al. 2011). Furthermore, in a full scale digester, the OLR doubled from 2.11 to $4.25 \mathrm{kgVS} \mathrm{m}^{-3} \mathrm{~d}^{-1}$, and stable operation was still achieved at an OLR of 5.5 $\mathrm{kgVS} \mathrm{m}^{-3} \mathrm{~d}^{-1}$ with maize and pig manure (Lindorfer et al. 2008).

In this study, the overloading of reactor (R3) occurred when the share of maize in the feedstock was increased to $67 \%$, and the OLR was $3 \mathrm{kgVS} \mathrm{m}^{-3} \mathrm{~d}^{-1}$. In the co-digestion of crop silage and cow manure, the overloading occurred in the OLR of $7.78 \mathrm{~kg} \mathrm{VS} \mathrm{m}^{-3} \mathrm{~d}^{-1}$, while the share of crop silage in the feedstock was 81 $\%$ VS (Comino et al. 2010); however, the process performed well at an OLR of $5.15 \mathrm{kgVS} \mathrm{m}^{-3} \mathrm{~d}^{-1}$, with the cow manure VS:crop silage VS was at 29:71 (Comino et al. 2010). In the present study, the HRT was 25 days, while in the study by Comino et al. (2010) it was ca. 42 days. In this study, the HRT was too short for efficient degradation, as the amount of non-degraded matter in the digestate increased leading to an increase in the post-methanation potential (Table 12).

The post-methanation potential was $23-48 \%$ of the total methane yields (the methane yields of the reactor plus post-methanation experiments) in this study. Thus it seems that even though the CSTR co-digesting maize and manure can be operated with higher OLRs and shorter HRTs, a significant part of the methane potential of the feedstock may be lost, and in the worst case even emitted into the atmosphere. In previous studies, the post-methanation potential increased when the OLR was raised in the reactor (Lehtomäki et al. 2007), and when the share of energy crops in the feedstock increased (Lindorfer 2007). The measured methane yields of the reactor experiments and post-methanation experiments were about 10 to $20 \%$ higher than the calculated methane yields 
TABLE 19 The co-digestion of the animal manure and maize material in the CSTRs operated within the mesophilic temperature as reported in the literature.

\begin{tabular}{lcccccl}
\hline \hline $\begin{array}{l}\text { Feedstock } \\
\text { (ratio on VS basis) }\end{array}$ & $\begin{array}{c}\text { Reactor } \\
\text { volume } \\
(\mathrm{l})\end{array}$ & $\begin{array}{c}\text { OLR } \\
\mathrm{kgVS} \\
\mathrm{m}^{-3} \mathrm{~d}-1\end{array}$ & $\begin{array}{c}\text { HRT } \\
\text { days }\end{array}$ & $\begin{array}{c}\text { Specific } \mathrm{CH}_{4} \\
\text { vield } \\
\text { l kgVS-1 }\end{array}$ & $\mathrm{CH}_{4}$ & Reference \\
\hline Cow manure, maize (80:20) & 5 & 2 & 27 & 198 & 52 & $(\mathrm{III})$ \\
Cow manure, maize (70:30) & 5 & 2 & 28 & 194 & 44 & (III) \\
Cow manure, maize (60:40) & 5 & 2 & 30 & 259 & 52 & (III) \\
Cow manure, maize (50:50) & 5 & 2 & 25 & 221 & 51 & (III) \\
Cow manure, maize (40:60) & 5 & 2.5 & 25 & 234 & 48 & (III) \\
Cow manure, maize (33:67) & 5 & 3 & 25 & 153 & 41 & $(\mathrm{III})$ \\
Pig manure, corn stover (75:25) & 30 & 3.84 & 16 & 210 & 67 & 1 \\
Cattle slurry, maize (100:0) & 5 & 2 & 33 & 171 & n.r. & 2 \\
Cattle slurry, maize (67:33) & 5 & 3 & 30 & 263 & n.r. & 2 \\
Cattle slurry, maize (50:50) & 5 & 4 & 28 & 304 & n.r. & 2 \\
Cattle slurry, maize (40:60) & 5 & 5 & 26 & 300 & n.r. & 2 \\
Cattle slurry, maize (50:50) & 5 & 3 & 29 & 240 & n.r. & 3 \\
Cattle slurry, maize (50:50) & 5 & 4 & 22 & 220 & n.r. & 3 \\
Cattle slurry, maize (50:50) & 5 & 5 & 18 & 210 & n.r. & 3 \\
Cattle slurry, maize (50:50) & 5 & 6 & 15 & 210 & n.r. & 3 \\
\hline \hline
\end{tabular}

n.r. not reported in the study

References: 1: Fujita et al. (1980), 2: Cornell et al. (2008), 3: Cornell et al. (2011).

from the feedstock in this study. The relatively high post-methanation potential also suggests that degradation of the feedstock was apparently not limited by lack of nutrients, but rather, by the short HRT, when the active bacterial population washed out in the reactor. The longer HRT of the reactor requires a larger volume of the digester, and hence, more capital costs. For energy crop digestion with manure, two-stage digester systems are preferred because of the high gas yield and reduced post-methanation potential. In two stage systems, the first reactor is a high-loaded main reactor, and the second reactor is low-loaded, which treats the digestate from the first reactor (Weiland 2010, Thamsiriroj \& Murphy 2011). Also, the storage tank should be covered to recover the methane.

The recirculation of the digestate back into the reactor (R3) did not increase the specific methane yield. The recycling of the digestate has been shown to improve gas production marginally, because the microbes have been returned to the digester, providing an additional microbial population (Yadvika et al. 2004, Thamsiriroj \& Murphy 2011). By increasing the recirculation of the digestate (only $6 \%$ WW of feedstock), the overloading of R3 may be prevented. Furthermore, too short HRTs (only 25 days) of the reactor might also be one reason for overloading. Cornell et al. (2011) also used a short HRT, only 15-29 days, when the reactors were fed OLR at $3-6 \mathrm{kgVS} \mathrm{m}^{-3} \mathrm{~d}^{-1}(50 \%$ of VS maize and $50 \%$ of VS cattle slurry), but then the methane yields were only $210-2401 \mathrm{kgVS}^{-1}$ (Table 19). The HRT was 33-43 days when the crop silage was fed as $51-71 \%$ of the feedstock VS (Comino et al. 2010). In both studies, there was no indication of overloading or process inhibition. 


\subsubsection{Nutrients and trace elements of the feed and digestate}

Maize had a lower nutrient and trace element concentration than the liquid cow manure in this study. The concentration of the nutrients and trace elements in the digestate decreased when the share of maize in the feedstock increased (Table 14). In an earlier study, the maize silage contained also fewer plant nutrients and trace elements than the digestate (Pobeheim et al. 2010). The lack of trace elements does not occur immediately, but only after a certain operation time (Lebuhn et al. 2008). The lack of trace elements has been reported in the monodigestion of grass-clover (Jarvis et al. 1997), however, especially in the case of the mono-digestion of maize (Lebuhn et al. 2008). Adding the trace elements to the reactor should attain: long-term process stability, and high methane production and operation at a higher OLR (Lebuhn et al. 2008). The co-digestion of maize with liquid cow manure helps to maintain the trace element concentration at a sufficient level of methane production, as manures typically contain a higher concentration of nutrients and trace elements (Angelidaki et al. 2003). On the other hand, as crops contain different concentrations of trace elements, which depend on the concentration of soil nutrients and regional variations in soil (Lindorfer et al. 2011), the need for trace nutrients in biogas plants should be assessed on a case by case basis.

In previous studies, the most limited trace elements in biogas production were reported to be Co, Mo, Se and Ni (Lebuhn et al. 2008, Pobeheim et al. 2011). The Co, Mo and Se were not analysed in the digestates in this study, but the $\mathrm{Ni}$ concentration of the digestate was between 2-16.6 $\mathrm{mg} \mathrm{kgTS}^{-1}$ (Table 14), corresponding to $0.09-0.66 \mathrm{~g} \mathrm{~m}^{-3}$, which was at the lower end of the range compared to optimum $\left(0.012-5 \mathrm{~g} \mathrm{~m}^{-3}\right)$ by Takashima \& Speece (1990). The Ni addition stimulated both the biogas production and the methane content of the biogas in the batch study, where cattle dung was used as a substrate (Demirel \& Scherer 2011). Previous studies have also shown that the appropriate addition of $\mathrm{Ni}$ and Co from the CSTR experiment (model substrate maize silage) provides an opportunity to increase the OLR in the reactor (Jarvis et al. 2007).

\subsection{Energy balance of cultivation energy crops for biogas production in boreal conditions}

The energy balance of the grass, maize and brown knapweed cultivation was calculated, and the input/output were 1.7-16.3\% (Table 15). The best energy balance $(1.7 \%)$ was achieved for the cultivation of brown knapweed because it is a perennial crop, the fertilization demand is low, and harvesting was done only one time during the growing season. In this study, grass showed a worse energy balance than maize due to the higher level of nitrogen fertilization $(170 \mathrm{kgN}$ $\mathrm{ha}^{-1}$ ), lower biomass yield per hectare, and harvesting two times per growing season, compared to maize and brown knapweed (Table 7). If the TS yield per hectare of grasses is considered among the results of the official variety trials 
(2005-2012) (Kangas et al. 2012), the TS yield will be an average of 10 tTS ha-1 $^{-1}$ and the energy balance will decrease in value to $3.6 \%$ (with fertilization digestate) and $12.1 \%$ (with the chemical fertilizer). In that case, the energy balance of maize and grass are the same.

The energy balance of biomass cultivation for biogas production was 1.9-27 $\%$ in previous studies (Table 20). The high difference in the energy balance is due to the biomass yield, the specific methane yield, fertilization used (digestate or chemical fertilizer) and different assumptions of given values. This is why the energy balances are difficult to compare. The energy balances of grasses and ley crops were $7-27 \%$ for grassland cultivation for biogas production, and the results of other studies are presented in Table 20. The worst energy balance (27.0 $\%)$ was achieved, for example, when the grasses were fertilized with chemical fertilizers and harvested four times per growing season (Pöschl et al. 2010). The energy balance was the best when the ley crops were cultivated in organic production without any pesticides, herbicides or chemical fertilization (Fredriksson et al. 2006). The energy balance of the maize cultivation in a previous study, fertilized with digestate was $4.4 \%$ and fertilized with a chemical fertilizer, $13.5 \%$, in Belgium (Table 20) (Gerin et al. 2008). In the cultivation of barley and turnip rape for bioethanol and biodiesel production, the energy balances were $21-28 \%$ and 31-33\%, respectively, when the manufacturing, repair and maintenance of the machines and buildings were considered (Mikkola et al. 2011).

The highest energy demands of the whole biogas production chain (from cultivation to produced biogas) (Fig 1.) are the heat and electricity demand for the heating and mixing of the digester, pumping the digestate, and feeding the reactor (Smyth et al. 2009, Korres et al. 2010). In previous studies, the heat consumption was 17.1-26.9 GJ ha-1 a $\mathrm{a}^{-1}$ (Smyth et al. 2009, Korres et al. 2010) and electricity consumption was 4.4-4.87 GJ ha-1 $\mathrm{a}^{-1}$ (Smyth et al. 2009, Korres et al. 2010). The heat consumption of the biogas plant is higher in boreal conditions because of the colder climate and lower average temperature $\left(4-5^{\circ} \mathrm{C}\right.$ in southern Finland) (Finnish Meteorological Institute 2013) compared with the climate in Germany and Austria (average temperature $9-11^{\circ} \mathrm{C}$ ) (Weather Online 2013). On the other hand, the biogas digesters fed with crops in southern and Central Europe may have to cool down in the summer because of the high reactor temperature, which is a result the of heat provided by metabolic generation (Cropgen 2007, Smyth et al. 2009)

In boreal conditions, the energy balance of the whole biogas production chain from grasses was 22-44 \% (Fredriksson et al. 2006, Berglund \& Börjesson 2006, Tuomisto \& Helenius 2008, Smyth et al. 2009). The energy balance of biogas using grass silage was higher $(46.6 \%)$, than the biogas plant using corn silage $(25.6 \%)$, in conditions in Germany (Pöschl et al. 2010). The energy balance of biogas was better than other biofuels (biodiesel $50 \%$ and bioethanol $80 \%$ ) in boreal conditions, and the greenhouse gas emissions from biogas production were lower than the emissions from biodiesel and bioethanol (Mäkinen et al. 2006, Tuomisto \& Helenius 2008). 
TABLE 20 The energy balance (input/output) of different crops used in bioenergy production in previous studies in Europe.

\begin{tabular}{|c|c|c|c|c|c|}
\hline \multirow[t]{2}{*}{ Crop/plant } & \multirow[t]{2}{*}{ End use } & \multicolumn{2}{|c|}{ Energy balance } & \multirow[t]{2}{*}{ Details } & \multirow[t]{2}{*}{ Ref. } \\
\hline & & $\begin{array}{c}\text { Cultivation } \\
\%\end{array}$ & $\begin{array}{l}\text { Whole chain } \\
\%\end{array}$ & & \\
\hline Maize & Biogas & $5.7^{a}$ & - & Fert. manure & 1 \\
\hline Maize & Biogas & $4.44^{\mathrm{a}}$ & - & Fert. digestate & 1 \\
\hline Maize & Biogas & $13.5^{\mathrm{a}}$ & - & Fert. chemical fert. & 1 \\
\hline Maize & Biogas & n.r. & $18.1^{\mathrm{a}}$ & Fert. chemical fert. & 9 \\
\hline Corn silage & Biogas & $15.5^{\mathrm{a}}$ & 25.6 & - & 4 \\
\hline Grass & Biogas & $7.2^{\mathrm{a}}$ & - & $\begin{array}{l}\text { Fert. digestate, } 4 \text { hasvest } \\
\text { time }\end{array}$ & 1 \\
\hline Grass & Biogas & $8.8^{a}$ & - & $\begin{array}{l}\text { Fert. digestate, } 2 \text { regrowth } \\
\text { harvest }\end{array}$ & 1 \\
\hline Grass & Biogas & $9.3^{\mathrm{a}}$ & - & $\begin{array}{l}\text { Fert. digestate, } 2 \text { harvest } \\
\text { times }\end{array}$ & 1 \\
\hline Ley & Biogas & $1.9^{a}$ & $21.6^{\mathrm{a}}$ & Organic production & 2 \\
\hline Grass & Biogas & 18.7 & 44 & Fert. chemical fert. & 6 \\
\hline Grass & Biogas & 11.5 & 37 & Fert. digestate & 6 \\
\hline Ley crops & Biogas & $8^{a}$ & 37 & Organic production & 5 \\
\hline Ley crops & Biogas & $9 a$ & 38 & Fert. digestate & 5 \\
\hline Grass Silage & Biogas & $27^{a}$ & 46.6 & Fert. chemical fert. & 4 \\
\hline Ley crops & Biogas & $22^{\mathrm{a}}$ & $40^{\mathrm{a}}$ & Fert. digestate & 3 \\
\hline $\begin{array}{l}\text { Leaves of sugar } \\
\text { beet }\end{array}$ & Biogas & 9 a & $27 \mathrm{a}$ & - & 3 \\
\hline Straw & Biogas & $10^{\mathrm{a}}$ & $35^{\mathrm{a}}$ & - & 3 \\
\hline $\begin{array}{l}\text { Whole wheat } \\
\text { plant silage }\end{array}$ & Biogas & $24.5^{\mathrm{a}}$ & 31.8 & Fert. chemical fert. & 4 \\
\hline Straw & Biogas & $4^{a}$ & 10.5 & - & 4 \\
\hline $\begin{array}{l}\text { Reed canary } \\
\text { grass }\end{array}$ & Biogas & $7^{a}$ & 29 & Organic production & 5 \\
\hline $\begin{array}{l}\text { Reed canary } \\
\text { grass }\end{array}$ & Biogas & $8.5^{\mathrm{a}}$ & 32 & Fert. chemical fert. & 5 \\
\hline Hemp & Biogas & $30^{\mathrm{a}}$ & $37 a$ & $\mathrm{CHP}$ & 7 \\
\hline Rapeseed & Biodiesel & - & 21.3 & Fert. chemical fert. & 9 \\
\hline Turnip rape & Biodiesel & $31-33$ & - & $\begin{array}{l}\text { Incl. manufacture/repair } \\
\text { machines/buildings }\end{array}$ & 8 \\
\hline $\begin{array}{l}\text { Winter } \\
\text { rapeseed }\end{array}$ & Biodiesel & $6.2^{\mathrm{a}}$ & $13.2^{\mathrm{a}}$ & Organic production & 2 \\
\hline Winter wheat & Bioethanol & $7.5^{\mathrm{a}}$ & $35.3^{a}$ & Organic production & 2 \\
\hline Barley & Bioethanol & $26-27$ & - & $\begin{array}{l}\text { Inc. manufacture/repair } \\
\text { machines/buildings }\end{array}$ & 8 \\
\hline Miscanthus & Combustion & - & 2.1 & No fert. & 9 \\
\hline Hemp & Combustion & $12.3^{\mathrm{a}}$ & $15^{\mathrm{a}}$ & $\mathrm{CHP}$ & 7 \\
\hline
\end{tabular}

aValue calculated from the article.

- not reported

Ref. = References: 1: Gerin et al. (2009), 2: Fredriksson et al. (2006), 3: Berglund \& Börjesson (2006), 4: Pöschl et al. (2010), 5: Tuomisto \& Helenius (2008), 6: Smyth et al. (2009), 7: Prade et al. (2012), 8: Mikkola et al. (2011), 9: Felten et al. (2013). 
To achieve a better energy balance and high methane yield, it should be determined whether it is reasonable, feasible and economical to harvest grasses two, three of four times per year. If the grasses are harvested three times per year, the specific methane yields remain stable because the harvested grass material has a good digestibility, and the TS yield remains almost the same; however, the energy (fossil fuel) needed to harvest the grasses increases and the net energy yield per hectare decreases. According to Gunnarsson et al. (2008), the harvesting of the grasses for biogas production was optimal (time, costs, capacity) at a later development stage than what is generally considered to be optimal for the harvesting of grasses for milk production. Also, the lowest grass silage production costs were calculated when the grass was harvested two times during the growing season, and the digestate was used as a fertilizer (McEniry et al. 2011). 


\section{CONCLUSIONS}

This thesis shows that biogas production from grasses, maize and novel energy crops can produce high methane yields per hectare in boreal conditions. The highest methane yield per hectare was achieved with maize in southern Finland (4 000-9 $200 \mathrm{~m}^{3} \mathrm{ha}^{-1} \mathrm{a}^{-1}$ ). The second highest methane yield was with brown knapweed harvested in July to August $\left(6100 \mathrm{~m}^{3} \mathrm{ha}^{-1} \mathrm{a}^{-1}\right)$, when the most feasible energy crops, grasses, produced only $1200-3600 \mathrm{~m}^{3} \mathrm{ha}^{-1} \mathrm{a}^{-1}$, obtaining the highest methane yields in the third harvest year.

However, maize cultivation for biogas production appears to be feasible only in southern Finland. The TS yields of maize were 11-21 tTS ha-1 in southern Finland and 6.8-10 tTS ha-1 in Central Finland; however, the cultivation and yield security have high variations, which are due to the different growing seasons. The short growing season and low heat summation limit maize growth in boreal conditions. For this reason, the variety should be tolerance for cool conditions and have an early maturing variety, especially in Central Finland. The significance of the maize variety is apparently not very important in southern Finland; because the later maturing maize varieties do not have time and they do not have to be fully matured, when cultivating maize for biogas process. The maize for biogas production is best harvested as late as possible in boreal conditions, in order to achieve high TS yields and high methane yields per hectare. The highest specific methane yields can be achieved when the whole maize crop is harvested for biogas production, because the whole maize crop contains nutrients that are suitable for anaerobic microbes, and the concentration of nutrients can be more conducive to methane production than using stems, leaves and cobs separately.

According to this study, cocksfoot, tall fescue and timothy are suitable producers of biomass for biogas production in boreal conditions, with no significant difference occurring between the specific methane yields, TS yield and methane yields per hectare of these grass species. Grassland cultivation is the most familiar way to produce biomass in boreal conditions, and the cultivation management, optimal harvest time concerning digestibility and high TS yields have been studied very carefully for feed production in animals. The grasses 
must be harvested two times per growing season, and cultivate grass mixtures, which contain grass species with a high biomass yield and regrowth ability to achieve high methane yields per hectare, and the digestate should be used as a fertilizer.

Brown knapweed was found to be the most promising novel energy crop for biogas production, producing up to $20 \mathrm{tTS} \mathrm{ha}^{-1}$ and $6000 \mathrm{~m}^{3} \mathrm{CH}_{4} \mathrm{ha}^{-1} \mathrm{a}^{-1}$, which is $40-50 \%$ more methane per hectare than the grasses in this study. Giant knotweed is also a promising novel energy crop for biogas production, but the harvest managements in boreal conditions have to be studied to achieve higher specific methane yields than in this study.

According to the results in the CSTR runs, maize and brown knapweed have suitable and feasible feeds for co-digestion with liquid cow manure. The anaerobic digestion processes (OLR $2 \mathrm{kgVS} \mathrm{m}^{3} \mathrm{~d}^{-1}$ ) were stable, and the highest methane yields were with maize (259 $\left.\mathrm{kgVS}^{-1}\right)(40 \%$ VS maize in the feed) and with brown knapweed (254 $\left.1 \mathrm{kgVS}^{-1}\right)$ (50\% VS brown knapweed in the feed). If the biogas process operated with a short HRT and high OLR, the postmethanation potential should be considered. When planning biogas plants, it must be ensured that the process runs at stable conditions, and that the produced methane can be used efficiently. The co-digestion with maize and liquid cow manure can be operated without the addition of trace elements, because the liquid cow manure contains the needed trace elements for stable anaerobic digestion process.

In this thesis, the energy balance (input/output) of the cultivation of maize, grass and brown knapweed was better with the digestate being used as fertilizer $(1.8-4.8 \%)$ than with chemical fertilizers (3.7-16.2 \%), the production of which was the most energy demanding process in the cultivation inputs. When considering the energy balance of the whole biogas process, the cultivation inputs are only 10-20\% of the whole energy input. The energy balance of cultivated feedstock for biogas production is better than the cultivation of rape seed for biodiesel production, or barley for bioethanol production, in boreal conditions.

When selecting traditional and novel energy crops for biogas production, they should be easy to cultivate, harvest and store, tolerant of weeds, pests, diseases, drought and frost, and have good winter hardiness in boreal conditions. The crop and plant biomass cultivation for biogas production is a good alternative in those cultivation areas where cereals are cultivated very intensively, and in monoculture, because the grass cultivation for biogas production improves the structure of the soil, increases the humus and carbon concentration of the soil and improves the growing conditions for the next year of cereal production. The green manure (clover grass) of organic farming could also be harvested for the anaerobic digestion process to produce biogas, after which the digestate could be used as a fertilizer in organic fields. 
Acknowledgements

The research work in this thesis was carried out in the Department of Biological and Environmental Science at the University of Jyväskylä. This work was financially supported by a grant from the University of Jyväskylä and the Department of Biological and Environmental Science, EU 6th Framework Programme, Peltoenergian tehostettu tuotanto (Efficient Production of Bioenergy in the Fields) project (funded by the Ministry of Agriculture and Forestry in Finland), and ENKAT-project (funded by the Rural Development Programme for Mainland Finland).

I gratefully thank my supervisor professor Jukka Rintala for the opportunity to do this research and for his guidance and patience during the writing of this thesis. I would also like to thank my other supervisor University Lecturer Prasad Kaparaju, PhD, for guidance and support through the final steps of this thesis and dissertation. Special thanks to my co-authors, Antti Laine, Annimari Lehtomäki, Teija Paavola, Ville Pyykkönen, and Ari Väisänen for their help with the laboratory work, planning and writing. I would also like to give special thanks to the laboratory technicians, Leena Siitonen and Mervi Koistinen, for their valuable help throughout the years, and to Nipa Pukkila, Suvi Bayr, Hanna Koponen, Viljami Kinnunen, and Ville Pyykkönen for their help with the laboratory work. Many thanks to Agrifood Research Finland (MTT) in Piikkiö, the Institute of Natural Resources, Jyväskylä University of Applied Sciences, Kalmari's biogas farm and K-maatalous experimental farm in Hahkiala for kindly providing the materials for this research. The warmest thank you goes to Suvi, Outi and Jenni, for sharing the troubles and joys of science, motherhood and everyday life. Thanks also go to other co-workers Teija, Saija, Hanne, Marja, Kati, Heli, Marina, Shanthi, Leena and Eeva for enjoyable discussions, inspiring company and help and advice whenever needed. I also wish to thank everyone in the Environmental Science section, and especially, to everyone joining in the coffee breaks, thanks for the discussions and support, those moments encouraged and helped me to finish this thesis.

Finally, I want to thank my family and friends for their support and friendship. Thank you to my parents-in-law, Salme and Antero, you have helped with our sons and at home more than you can know. My warmest thanks go to my parents, Ulla and Kari, for helping and supporting me in all areas of my life. You have made this possible.

Last but not least, I want to thank my beloved husband, Antti for his love, support and encouragement. Kalle and Viljo, my two wonderful and lively sons, you have given me something else to do and think about during this work. 


\section{YHTEENVETO (RÉSUMÉ IN FINNISH)}

\section{Biokaasun tuotanto suurisatoisista energiakasveista pohjoisissa olosuhteissa}

Lisäämällä uusiutuvan energian tuotantoa voidaan vähentää riippuvuutta fossiilisista polttoaineista ja vähentää kasvihuonekaasupäästöjä. Biokaasun tuotanto on yksi tapa tuottaa kotimaista ja uusiutuvaa energiaa. Biokaasua, joka koostuu pääosin metaanista $45-70 \%$ ja hiilidioksidista $25-50 \%$, voidaan tuottaa hapettomissa olosuhteissa energiakasveista, kasvijätteistä ja muista orgaanisista jätteistä. Tuotettu biokaasu voidaan käyttää sähkön- ja lämmöntuotannossa sekä puhdistaa ja paineistaa biometaaniksi joko liikenteen käyttöön tai syötettäväksi suoraan kaasuverkkoon. Biokaasuprosessi tuottaa myös prosessijän̈nnöstä, joka voidaan käyttää hyväksi lannoitteena energiakasvien viljelyssä, jolloin voidaan saavuttaa lähes suljettu ravinnekierto.

Tässä väitöstyössä tutkittiin nurmikasvien, maissin ja uudenlaisten energiakasvien ( $\mathrm{mm}$. luonnonkasveja, rikkakasveja ja $\mathrm{C}_{4}$ kasveja) metaanintuottoa peltohehtaaria kohden. Tutkimuksessa määritettiin erilaisten kasvien metaanintuottopotentiaalit ja kuiva-ainesadot sekä korjuuajan vaikutus nurmikasvien, maissin ja ahdekaunokin metaanintuottopotentiaaleihin ja kuiva-ainesatoihin. Maissin ja ahdekaunokin biokaasuprosessin toimivuutta tutkittiin yhdessä lehmän lietelannan kanssa laboratoriomittakaavan biokaasureaktoreissa. Nurmikasvien, maissin ja ahdekaunokin viljelyn energiataseet laskettiin sekä käyttäen väkilannoitetta että lannoittamalla kasvit biokaasuprosessin jäännöksellä.

Korkeimmat metaanintuottopotentiaalit hehtaaria kohden saatiin maissilla 4 000-9 $200 \mathrm{~m}^{3} \mathrm{ha}^{-1}$ eteläisessä Suomessa. Toiseksi eniten metaania tuotti ahdekaunokki korjattuna heinä-elokuussa $6100 \mathrm{~m}^{3} \mathrm{ha}^{-1}$, kun pohjoisiin olosuh-teisiin kaikkein potentiaalisin energiakasvi, nurmi, tuotti vain $1200-3600 \mathrm{~m}^{3}$ ha $^{-1}$. Maissin viljely biokaasun tuotantoon näyttää olevan mahdollista vain EteläSuomessa (sato 11-21 t kuiva-ainetta (TS) ha ${ }^{-1}$ ), koska satotaso Keski-Suomessa oli vain 6,8-10 tTS ha-1, mikä on samaa tasoa tässä tutkimuksessa saadun nurmen satotason kanssa (6-13 tTS ha-1). Lyhyt kasvukausi ja matala tehoisa lämpösumma rajoittavat maissin kasvua, kun taas nurmet ja ahdekaunokki ovat satovarmoja koko Suomessa. Maissin paras korjuuaika biokaasun tuotantoon on myöhään ennen ensimmäisiä syyspakkasia, jotta mahdollisimman suuri kuivaainesato hehtaaria kohden voidaan saavuttaa, vaikka kasvibiomassan metaanintuottopotentiaali laskee. Tutkimuksen mukaan nurmikasveista timotei, koiranheinä ja ruokonata sopivat paremmin biokaasuntuotantoon kuin ruokohelpi, jonka jälkikasvukyky on heikompaa ja kuiva-ainesadot alenivat kasvuston 1. satovuoden jälkeen. Tässä tutkimuksessa ahdekaunokki saavutti korkeat kuivaainesadot 15-23 tTS ha- ${ }^{-1}$ Etelä-Suomessa ja aikaisemmissa tutkimuksissa korkeita kuiva-ainesatoja on saavutettu koko Suomessa. Ahdekaunokki on luonnonkasvi, joka käyttää typpeä tehokkaasti tuottaen paljon kuiva-ainesatoa. Ahdekaunokki säilytti korkean metaanintuoton hehtaaria kohden kuiva-ainesadon kasvaessa ja metaanintuottopotentiaalin alentuessa kasvukauden edetessä.

Korkein metaanintuottopotentiaali saavutettiin maisseilla 240-500 $1 \mathrm{kgVS}^{-1}$ (orgaanista ainetta kohti) ja toiseksi korkein nurmikasveilla 250-390 $1 \mathrm{kgVS}^{-1}$, ah- 
dekaunokin ja muiden uudenlaisten energiakasvien metaanintuottopotentiaalin jäädessä matalammalle 170-380 1 kgVS-1. Metaanintuottopotentiaali laski kasvukauden edetessä sekä maissilla että ahdekaunokilla. Nurmen ensimmäisen sadon metaanintuottopotentiaali oli korkeampi verrattuna toisen sadon metaanintuottopotentiaaliin.

Useimmat biokaasulaitokset käsittelevät energiakasveja tai orgaanisia jätteitä yhdessä erilaisten lietemäisten jätteiden, kuten lietelannan kanssa. Lietelanta takaa alhaisen kuiva-ainepitoisuuden takia riittävästi vettä mikrobeille, prosessin puskurointikykyä sekä tarvittavat ravinteet tasapainoiselle anaerobiselle hajoamiselle. Maissin ja ahdekaunokin toimivuutta biokaasu-reaktorissa tutkittiin yhdessä lehmän lietelannan kanssa. Suurin metaanintuotto (259 $\left.1 \mathrm{kgVS}^{-1}\right)$ maissireaktoreissa saavutettiin, kun maissin osuus syötteessä oli $40 \%$ reaktoriin syötetystä orgaanisesta aineesta kuormituksen ollessa $2 \mathrm{~kg} \mathrm{VS} \mathrm{m}^{-3} \mathrm{~d}^{-1}$. Ahdekaunokilla suurin metaanintuotto (254 $\left.1 \mathrm{kgVS}^{-1}\right)$ saatiin samalla kuormituksella (2 $\mathrm{kg} \mathrm{VS} \mathrm{m}^{-3}$ $\mathrm{d}^{-1}$ ), kun ahdekaunokin osuus oli 50 \% syötteen orgaanisesta aineesta. Reaktorikokeissa saadut metaanisaannot vastasivat 76-105 \%:sti käsiteltyjen materiaalien metaanintuottopotentiaaleja. Reaktorikokeissa mitattiin myös prosessijäännöksen jälkikaasutuspotentiaali. Jälkikaasutuspotentiaali kasvoi, kun kasvin osuus reaktorin syötteessä kasvoi. Tämän vuoksi prosessijäännös täytyy varastoida ilmatiiviiseen varastointialtaaseen, jotta metaanipäästöt ilmaan voidaan välttää ja jotta kaikki tuotettu energia saadaan talteen. Korkean metaanintuoton takia biokaasuprosessissa täytyy olla riittävät määrät ravinteita ja hivenravinteita mikrobien suorittaman anaerobisen hajoamisen saavuttamiseksi. Tässä tutkimuksessa ei havaittu metaanintuoton alenemista liittyen hivenravinteisiin, koska reaktoreihin lisättiin riittävä määrä lietelantaa mikrobien toiminnan kannalta.

Nurmikasvien, maissin ja ahdekaunokin viljelyn energiatase laskelmissa kasvit tuottivat bruttoenergiaa 79 900, 140400 ja $138600 \mathrm{MJ} \mathrm{ha}^{-1}$, tässä järjestyksessä. Kasvien viljelyssä korkein energiapanos on kemiallisten lannoitteiden käyttö viljelyssä. Sen osuus oli yli $50 \%$ koko viljelyn energian-kulutuksesta. Käyttämällä energiakasvien viljelyssä prosessijäännöstä lannoitteena voidaan lannoitukseen tarvittavaa energiankulutusta pienentää huomattavasti. Energiakasvien viljelyyn kuluva polttoaine on toinen suuri energiapanos. Yksivuotisen maissin viljelyssä jokavuotinen maan kylvömuokkaus kuluttaa energiaa huomattavasti ja monivuotisen nurmen viljelyssä taas kahteen kertaan tapahtuva sadonkorjuu on huomattava energiapanos. Parhain energiatase tässä tutkimuksessa saatiin ahdekaunokin viljelyssä, käyttämällä prosessijäännöstä lannoitteena $(1,8$ \%). Maissin energiatase sekä prosessijäännöksellä (3,6 \%) että kemiallisilla lannoitteilla $(6,8 \%)$ oli parempi kuin nurmenviljelyn (4,8 \% ja 16,2 \%), johtuen nurmelle sallitusta suuremmasta typpilannoitusmäärästä $\left(170 \mathrm{~kg} \mathrm{~N}^{-1}\right)$ kuin maissilla (90 kg N ha-1). Energia-kasvien viljely biokaasuntuotantoon kuluttaa kuitenkin koko tuotantoketjun energiankulutuksesta noin 10-20 \% sähkön ja lämmön kulutuksen ollessa suurin energiapanos biokaasun tuotantoketjussa. 


\section{REFERENCES}

Alburquerque J.A., de la Fuente C., Ferrera-Costa A., Carrasco L., Cegarra J., Abad M. \& Bernal M.P. 2012. Assessment of the fertilizer potential of digestates from farm and agroindustrial residues. Biomass Bioenergy 40: 181189.

Amon T., Amon B., Kryvoruchko V., Machmüller A., Hopfner-Sixt K., Bodiroza V., Hrbek R., Friedel J., Pötsch E., Wagentristl H., Schreiner M. \& Zollitsch W. 2007a. Methane production through anaerobic digestion of various energy crops grown in sustainable crop rotations. Bioresour. Technol. 98: 3204-3212.

Amon T., Amon B., Kryvoruchko V., Zollitsch W., Mayer K. \& Gruber, L. 2007b. Biogas production from maize and dairy cattle manure - Influence of biomass composition on the methane yield. Agric. Ecosyst. Environ. 118: 173182.

Angelidaki I. \& Ellegaard L. 2010. Codigestion of manure and organic wastes in centralized biogas plant. Appl. Biochem. Biotechnol. 109: 95-105.

Bachmaier J., Effenberger M. \& Gronauer A. 2010. Greenhouse gas balance and resource demand of biogas plants in agriculture. Eng. Life Sci. 10: 560-569.

Berglund M. \& Börjesson P. 2006. Assessment of energy performance in the lifecycle of biogas production. Biomass Bioenergy 30: 254-266.

Boulamanti A.K., Maglio S.D., Giuntoli J. \& Agostini A. 2013. Influence of different practices on biogas sustainability. Biomass Bioenergy 53: 149-161.

Bruinenberg M.H., Valk H., Korevaar H. \& Struik P.C. 2002. Factors affecting digestibility of temperate forages from seminatural grasslands: review. Grass Forage Sci. 57: 292-301.

Bruni E., Jensen A.P., Pedersen E.S. \& Angelidaki I. 2010. Anaerobic digestion of maize focusing on variety, harvest time and pretreatment. Appl. Energy 87 (7): 2212-2217.

Byrne K.A., Kiely G. \& Leahy P. 2007. Carbon sequestration determined using farm scale carbon balance and eddy covariance. Agric. Ecosyst. Environ. 121: 357-364.

Cavinato C., Fatone F., Bolzonella D. \& Pavan P. 2010. Thermophilic anaerobic co-digestion of cattle manure with agro-wastes and energy crops: Comparison of pilot and full scale experiences. Bioresour. Technol. 101: 545550.

Chandra R., Takeuchi H. \& Hasegawa T. 2012. Methane production from lignocellulosic agricultural crop waste: A review in context to second generation of biofuel production. Renewable Sustainable Energy Rev. 16: 14621476.

Christou M., Alexopoulou E., Panoutsou C. \& Monti A. 2010. Overview of the markets for energy crops in EU27. Biofuels, Bioprod. Biorefin. 4: 605-619. 
Chynoweth D.P., Turick C.E., Owens J.M., Jerger D.E. \& Peck M.W. 1993. Biochemical methane potential of biomass and waste feedstocks. Biomass Bioenergy 5: 95-111.

Comino E., Rosso M. \& Riggio V. 2010. Investigation of increasing organic loading rate in the co-digestion of energy crops and cow manure mix. Bioresour. Technol. 101: 3013-3019.

Cornell M., Banks C.J. \& Heaven S. 2008. Impact of the addition of maize on the anaerobic digestion of cattle slurry. Vth Seminar on Anaerobic digestion of solid waste and energy crops. Hammamet, Tunis, May 25-28.

Cornell M., Banks C.J. \& Heaven S. 2011. Effect of increasing the organic loading rate on the co-digestion and mono-digestion of cattle slurry and maize. International IWA-symposium on Anaerobic digestion of solid waste and energy crops. Wien, Austria, August 28-September 01.

Cropgen 2007. Assessment of the potential for crop-derived biogas as an energy source in the EU, taking into account technical and environmental issues and socioeconomic impact. University of Southampton. http://www.cropgen. soton.ac.uk/deliverables (accessed on 13.4.2013)

Dalgaard T., Halberg N. \& Porter J.R. 2001. A model for fossil energy use in Danish agriculture used to compare organic and conventional farming. Agric., Ecosyst. Environ. 87: 51-65.

Darby H.M. \& Lauer J.G. 2002. Harvest date and hybrid influence on corn forage yield, quality and preservation. Agron J 94 (3): 559-566.

Demirel B. \& Scherer P. 2011. Trace element requirements of agricultural biogas digesters during biological conversion of renewable biomass to methane. Biomass Bioenergy 35: 992-998.

Deublein D. \& Steinhauser A. 2012. Biogas from Waste and Renewable Resources. An Introduction, Second Revised and Expanded Edition. Wiley-VCH Verlag GmbH \& Co. KGaA, Weinheim.

Drosg B. 2012. Austrian country report. IEA Bioenergy Task 37, November. http://www.iea-biogas.net/_content/publications/member-countryreports.html (accessed on 13.4.2013)

Edwards R., Griesemann J.-C., Larivé J.-F. \& Mahieu V. 2003. Well-to-Wheels Analysis of Future automotive Fuels and Powertrains in the European Context. Jointly carried out by EUCAR, CONCAWE and JRC/IEA. Well-to-Tank Report Version 1, December 2003.

Ettle T. \& Schwarz F.J. 2003. Effect of maize variety harvested at different maturity stages on feeding value and performance of dairy cows. Anim. Res. 52: 337-349.

European union 2009. EU Directive 2009/28/EC of the European Parliament and of the Council of 23 April 2009 on the promotion of the use of energy from renewable sources. http://eur-lex.europa.eu/LexUriServ/LexUriServ.do?uri=CELEX: 32009L0028:EN:NOT (accessed on 13.3.2013)

Fazio S. \& Monti A. 2011. Life cycle assessment of different bioenergy production systems including perennial and annual crops. Biomass Bioenergy 35: 48684878 . 
Felten D., Fröba N., Fries J. \& Emmerling C. 2013. Energy balance and greenhouse gas-mitigation potentials of bioenergy cropping systems (Miscanthus, rapeseed, and maize) based on farming conditions in Western Germany. Renewable Energy 55: 160-174.

Finlex 2000. Valtioneuvoston asetus maataloudesta peräisin olevien nitraattien vesiin pääsyn rajoittamiseksi 931/2000. http://www.finlex.fi/fi/laki/alkup/ 2000/20000931\#Pid1901313 (accessed on 13.3.2013)

Finnish meteorological institute 2007. Thermal growing season 2007 (in Finnish). http://www.fmi.fi/saa/tilastot_168.html (accessed on 16.06.2010)

Finnish meteorological institute 2008. Thermal growing season 2008 (in Finnish). http://www.fmi.fi/saa/tilastot_168.html (accessed on 16.06.2010)

Finnish meteorological institute 2013. The average temperature of year 1981-2010. http:/ / ilmatieteenlaitos.fi/vuositilastot (accessed on 18.05.2013)

Finnish Standard Association 1990. SFS 3008. Determination of total residue and total fixed residue in water, sludge and sediment. Finnish Standard Association, Helsinki, Finland.

Finnish Standard Association 2002a. SFS 5504. Determination of chemical oxygen demand $\left(C O D_{C r}\right)$ in water with closed tube method, oxidation with dichromate. Finnish Standard Association, Helsinki, Finland.

Finnish Standard Association 2002b. SFS-EN 12457-4. Characterization of waste. Leaching. Compliance test for leaching of granular waste materials and sludges. Part: 4 One stage batch test at a liquid to solid ratio of $10 \mathrm{l} / \mathrm{kg}$ for materials with particle size below $10 \mathrm{~mm}$ (without or with size reduction). Finnish Standard Association, Helsinki, Finland.

FNR 2009. Biogas-Messprogramm II - 61 Biogasanlagen im Vergleich. Fachagentur Nachwachsende Rohstoffe. http://www.nachwachsenderohstoffe.de/ (accessed on 13.4.2013)

FNR 2013a. Anbaufläche für nachwachsende Rohstoffe 2012. http://mediathek.fnr.de/grafiken/daten-und-fakten/anbauflache-furnachwachsende-rohstoffe-2012-grafik.html (accessed on 13.4.2013)

FNR 2013b. Entwicklung Biogasanlagen. http://mediathek.fnr.de/grafiken/datenund-fakten/bioenergie/biogas/entwicklung-biogasanlagen.html (accessed on 13.4.2013)

Fredriksson H., Baky A., Bernesson S., Nordberg Å., Norén O. \& Hansson P.-A. 2006. Use of farm produced biofuels on organic farms - evaluation of energy balances and environmental loads for three possible fuels. Agr. Sys. 89: 184-203.

Freibauer A., Rounsevell M.D.A., Smith P. \& Verhagen J. 2004. Carbon sequestration in the agricultural soils of Europe. Geoderma 122: 1-23

Frigon J.-C. \& Guiot S.R. 2010. Biomethane production from starch and lignocellulosic crops: a comparative review. Biofuels, Bioprod. Biorefin. 4: 447-458.

Fujita M., Scharer J.M. \& Moo-Young M. 1980. Effect of corn stover addition on the anaerobic digestion of swine manure. Agric. Wastes 2: 177-184. 
Gao R., Yuan X., Zhu W., Wang X., Chen S., Cheng X. \& Cui Z. 2012. Methane yield through anaerobic digestion for various maize varieties in China. Bioresour. Technol. 118: 611-614.

Geber U. 2002. Cutting frequency and stubble height of reed canary grass (Phalaris arundinaceae L.): Influence on quality and quantity of biomass for biogas production. Grass Forage Sci. 57: 389-394.

Gerin P.A., Vliegen F. \& Jossart J.-M. 2008. Energy and $\mathrm{CO}_{2}$ balance of maize and grass as energy crops for anaerobic digestion. Bioresour. Technol. 99: 26202627.

Gilliland T.J. 1997. Changes induced by defoliation in the yield and digestibility of leaves and stem of perennial ryegrass (Lolium perenne L.) during reproductive development. Eur. J. Agron. 6: 257-264.

Giuliano A., Bolzonella D., Pavan P., Cavinato C. \& Cecchi F. 2013. Co-digestion of livestock effluents, energy crops and agro-waste: Feeding and process optimization in mesophilic and thermophilic conditions. Bioresour. Technol. 128: 612-618.

Griffin T., Giberson E. \& Wiedenhoeft M. 2002. Yield response of long-term mixed grassland swards and nutrient sources and management regimes. Grass Forage Sci. 57: 268-278.

Grönroos J. \& Voutilainen P. 2001. Maatalouden tuotantotavat ja ympäristö, Inventaarioanalyysin tulokset. Suomen ympäristökeskuksen moniste 231. http:// www.ymparisto.fi/ download.asp?contentid=15182 (accessed on 8.5.2013)

Gunaseelan V.N. 1997. Anaerobic digestion of biomass for methane production: a review. Biomass Bioenergy 13: 83-114.

Gunnarsson C., Vågström L. \& Hansson P.-A. 2008. Logistics for forage harvest to biogas production - Timeliness, capacities and costs in a Swedish case study. Biomass Bioenergy 32: 1263-1273.

Hakala K. \& Peltonen-Sainio P. 2008. Tuleeko Suomesta vilja-aitta, kun ilmasto muuttuu? (in Finnish). Maataloustieteen Päivät 2008 (electronic publishing). In: Hopponen A. (ed). Suomen Maataloustieteellisen Seuran tiedotteita no 23. at: http://www.smts.fi (accessed on 13.6.2010)

Hakkola H. 1998. Lannoitus. In: Nurmenviljely. Maaseutukeskusten Liiton julkaisuja. Tieto tuottamaan 77, Satakunnan Painotuote Oy, Kokemäki. (in Finnish)

Hendriks A.T.W.M. \& Zeeman G. 2009. Pretreatments to enhance the digestibility of lignocellulosic biomass. Bioresour. Technol. 100: 10-18.

Herrmann C., Heiermann M. \& Idler C. 2011. Effects of ensiling, silage additives and storage period on methane formation of biogas crops. Bioresour. Technol. 102: 5153-5161.

Herrmann A. \& Rath J. 2012. Biogas production from maize: Current state, challenges and prospects. 1. Methane yield potential. Bioenergy Res. 5: 10271042.

Herrmann A. 2013. Biogas production from maize: Current state, challenges and prospects. 2. Agronomic and environmental aspects. Bioenergy Res. 6: 372387. 
Hinken L., Urban I., Haun E., Urban I., Weichgrebe D. \& Rosenwinkel K.-H. 2008. The valuation of malnutrition in the mono-digestion of maize silage by anaerobic batch tests. Water Sci. Technol. 58 (7): 1453-1459.

Holmes W. 1980. Grass: Its production and utilization. Blackwell Scientific Publications, Oxford, UK.

Huhtanen P., Nousiainen J. \& Rinne M., 2006. Recent developments in forage evaluation with special reference to practical applications. Agric. Food Sci. 15: 293-323.

Huttunen M.J. \& Kuittinen V. 2012. Suomen biokaasulaitosrekisteri n:o 15, tiedot vuodelta 2011. Publications of the University of Eastern Finland, Reports and Studies in Forestry and Natural Science No 8. (Finnish, Abstract in English). http://www.biokaasuyhdistys.net/media/Biokaasulaitosrekisteri2011.pdf (accessed on 14.4.2013)

Hyytiäinen T., Hedman-Partanen R. \& Hiltunen S. 1999. Kasvintuotanto 2. Kirjapaino Oy West point, Rauma. (in Finnish)

IPCC 2007. Summary for Policymakers. In: Parry M.L., Canziani O.F., Palutikof J.P., van der Linden P.J. \& Hanson C.E. (eds), Climate Change 2007: Impacts, Adaptation and Vulnerability. Contribution of Working Group II to the Fourth Assessment Report of the Intergovernmental Panel on Climate Change. Cambridge, United Kingdom, Cambridge University Press, pp. 7-22.

Ito M., Shimazu Y., Yamaguchi H., Ito M. \& Toyoda T. 1997. Seasonal trends of tiller emergence and senescence in several temperate herbage grasses grown under sward conditions. Grassland Sci. 43 (1): 7-13.

Jarvis ̊., Nordberg ̊̊., Jarlsvik T., Mathisen B. \& Svensson B.H. 1997. Improvement of a grass-clover silage-fed biogas process by the addition of cobalt. Biomass Bioenergy 12: 453-460.

Jensen C., Weisbjerg M.R., Nørgaard P. \& Hvelplund T. 2005. Effect of maize silage maturity on site of starch and NDF digestion in lactating dairy cows. Anim. Feed Sci. Technol. 118 (3-4): 279-294.

Jones M.B. \& Donnelly A. 2004. Carbon sequestration in temperate grassland ecosystems and the influence of management, climate and elevated $\mathrm{CO}_{2}$. New Phytologist 164: 423-439.

Kandel T.P., Sutaryo S., Møller H.B., Jørgensen U. \& Lærke P.E. 2013. Chemical composition and methane yield of reed canary grass as influenced by harvesting time and harvest frequency. Bioresour. Technol. 130: 659-666.

Kangas A., Högnäsbacka M., Kujala M., Laine A., Niskanen M., Jauhiainen L. \& Nikander H. 2012. Results of official variety trials 2005-2012. MTT Agrifood Research, Jokioinen, Finland. http://www.mtt.fi/mttraportti/ pdf/mttraportti75.pdf. (accessed on 14.4.2013)

Kaparaju P., Luostarinen S., Kalmari E., Kalmari J. \& Rintala J. 2002. Co-digestion of energy crops and industrial confectionery by-products with cow manure: batch-scale and farm-scale evaluation. Water Sci. Technol. 45: 275-280.

Kapuinen P., Perälä P. \& Regina K. 2008. Mädätyksen vaikutus naudan lietelannan lannoitusominaisuuksiin nurmella. In: Hopponen A. (ed.) Maataloustieteen Päivät 2008 (electronic publishing). Suomen 
Maataloustieteellisen Seuran tiedotteita no 23 (in Finnish). http://www.smts.fi (accessed on 14.4.2010)

Kelm M., Wachendorf M., Trott H., Volkers K. \& Taube F. 2004. Performance and environmental effects of forage production on sandy soils. III. Energy efficiency in forage production from grassland and maize for silage. Grass Forage Sci. 59: 69-67.

Khalsa J., Fricke T., Weigelt A. \& Wachendorf M. 2012. Effects of species richness and functional groups on chemical constituents relevant for methane yields from anaerobic digestion: results from a grassland diversity experiment. Grass Forage Sci. doi: 10.1111/gfs.12028

Klimiuk E., Pokój T., Budzýnski W. \& Dubis B. 2010. Theoretical and observed biogas production from plant biomass of different fibre contents. Bioresour. Technol. 101: 9527-9535.

Korres E., Singh A., Nizami A.S. \& Murphy J.D. 2010. Is grass biomethane a sustainable transport biofuel. Biofuels, Bioprod. Biorefin. 4: 310-325.

Kreps R. 2010. Energy maize breeding -current state. http://www.tll.de/ainfo/ pdf/epfl/epf11_08.pdf (accessed on 15.06.2010)

Kruse S., Herrmann A., Kornher A. \& Taube F. 2008. Evaluation of genotype and environmental variation in fibre content of silage maize using a modelassisted approach. Eur J Agron 28 (3): 210-223.

Kuhlman T., Diogo V. \& Koomen E. 2012. Exploring the potential of reed as a bioenergy crop in the Netherlands. Biomass Bioenergy 55: 41-52.

Kuoppala K., Rinne M., Nousiainen J. \& Huhtanen P. 2008. The effect of cutting time of grass silage in primary growth and regrowth and the interactions between silage quality and concentrate level on milk production of dairy cows. Livest. Sci. 116: 171-182.

Lebuhn M., Liu F., Heuwinkel H. \& Gronauer A. 2008. Biogas production from mono-digestion of maize silage-long term process stability and requirements. Water Sci. Technol. 8: 1645-1651.

Lebzien S., Veste M., Fechner H., Koning L., Mantovani D. \& Freese D. 2012. The giant knotweed (Fallopia sachalinensis var. Igniscum) as a new plant resource for biomass production for bioenergy. Geophysical Res. Abst. 14

Lehtomäki A., Huttunen S. \& Rintala J.A. 2007. Laboratory investigations on codigestion of energy crops and crop residues with cow manure for methane production: Effect of crop to manure ratio. Resour., Conserv. Recycl. 51: 591609.

Lehtomäki A., Viinikainen T.A. \& Rintala J.A. 2008. Screening boreal energy crops and crop residues for methane biofuel production. Biomass Bioenergy 36: 3267-3278.

Lide D.R. \& Frederikse H.P.R. 1996. CRC Handbook of Chemistry and Physics. 77th edition. CRC Press inc. USA.

Lindorfer H., Perez Lopez C., Resch C., Braun R. \& Kirchmayr R. 2007. The impact of increasing energy crop addition on performance and residual methane potential in anaerobic digestion. Water Sci. Technol. 56: 55-63. 
Lindorfer H., Corcoba A., Vasilieva V., Braun R. \& Kirchmayr R. 2008. Doupling the organic loading rate in the co-digestion of energy crops and manure $-\mathrm{A}$ full scale case study. Bioresour. Technol. 99: 1148-1156.

Lindorfer H., Ramhold D. \& Frauz B. 2011. Nutrient and trace element supply in $\mathrm{AD}$ plants and effect of trace element application. International IWAsymposium on Anaerobic digestion of solid waste and energy crops. Wien, Austria August 28- September 01.

Madsen M., Holm-Nielsen J.B. \& Esbensen K.H. 2011. Monitoring of anaerobic digestion processes: A review perspective. Renewable Sustainable Energy Rev. 15: 3141-3155.

Mahmood A. \& Honermeier B. 2012. Chemical composition and methane yield of sorghum cultivars with contrasting row spacing. Field Crops Res. 128: 27-33.

Mähnert P., Heiermann M. \& Linke B. 2005. Batch- and semi-continuous biogas production from different grass species. Agricultural Engineering International: the CIGR Ejournal. Manuscript 05010 Vol. VII.

Mäkinen T., Soimakallio S., Paappanen T., Pahkala K. \& Mikkola H. 2006. Liikenteen biopolttoaineiden ja peltoenergian kasvihuonekaasutaseet ja uudet liiketoimintakonseptit (in Finnish, with English abstract). VTT Report. 141 p.

Massé D., Gilbert Y., Savoie P., Bélanger G., Parent G. \& Babineau D. 2010. Methane yield from switchgrass harvested at different stages of development in Easter Canada. Bioresour. Technol. 101: 9536-9541.

Matsunaka T., Sawamoto T. \& Ishimura H. 2006. Efficient use of digested cattle slurry from biogas plant with respect to nitrogen recycling in grassland. Inter. Congress Series 1293: 242-252.

Mavi 2009. Guide of fertilization considering environmental aid, Opas ympäristötukiehtojen mukaiseen lannoitukseen (in Finnish). http://www.mavi.fi/attachments/mavi/viljelijatuet/hakuoppaatjaohjeet/ ymparistotuenperusjalisatoimenpiteidenoppaat/5FSJ2pUCH/912996_lanno iteopas_LR_vii.pdf (accessed on 21.3.2013)

McEniry J., O'Kiely P., Crosson P., Groom E. \& Murphy J.D. 2011. The effect of feedstock cost on biofuel cost as exemplified by biomethane production from grass silage. Biofuels, Bioprod. Biorefin. 5: 670-682.

McEniry J. \& O'Kiely P. 2013. Anaerobic methane production from five common grassland species at sequential stages of maturity. Bioresour. Technol. 127: 143-150.

McKendry P. 2002. Energy production from biomass (part 1): overview of biomass. Bioresour. Technol. 83: 37-46.

Menardo S., Gioelli F. \& Balsari P. 2011. The methane yield of digestate: Effect of organic loading rate, hydraulic retention time, and plant feeding. Bioresour. Technol. 102: 2348-2351.

Meulepas R.J.A., Nordberg A., Mata-Alvarez J. \& Lens P.N.L. 2005. Methane production from waste water, solid waste and biomass. In: Lens P., Westermann P., Haberbauer M. \& Moreno A. (eds.), Biofuels for fuel cells: Renewable energy from biomass fermentation, IWA Publishing, London, UK, pp. 121-138. 
Mikkola H.J. \& Ahokas J. 2009. Energy ratios in Finnish agricultural production. Agric. Food Sci. 18: 332-346.

Mikkola H., Pahkala K. \& Ahokas J. 2011. Energy consumption in barley and turnip rape cultivation for bioethanol and biodiesel (RME) production. Biomass Bioenergy 35: 505-515.

Möller K. \& Müller T. 2012. Effect of anaerobic digestion on digestate nutrient availability and crop growth: A review. Eng. Life Sci. 12 (3): 242-257.

Morrison T.A., Jung H.G., Buxton D.R. \& Hatfield R.D. 1998. Cell-wall composition of maize internodes of varying maturity. Crop Sci. 38 (2): 455460.

Murphy J.D. \& Power N.M. 2008. How can we improve the energy balance of ethanol production from wheat? Fuel 87 (10-11): 1799-1806.

Murphy J.D. \& Power N.M. 2009. An argument for using biomethane generated from grass as a biofuel in Ireland. Biomass Bioenergy 33: 504-512.

Nges I.A. \& Björnsson L. 2012. High methane yields and stable operation during anaerobic digestion of nutrient-supplemented energy crop mixtures. Biomass Bioenergy 47: 62-70.

Nges I.A., Björn A. \& Björnsson L. 2012. Stable operation during pilot-scale anaerobic digestion of nutrient-supplemented maize/sugar beet silage. Bioresour. Technol. 118: 445-454.

Niiranen R. 2008. MTT Maaningalla tutkitaan maissia (in Finnish). Maaseudun tiede 65. http://www.mtt.fi/maaseuduntiede/pdf/mtt-mt-v65n03s09.pdf. (accessed on 14.6.2010)

Nissinen O. 2004. Lisää satoa säilörehunurmesta (in Finnish). Koetoiminta ja Käytäntö 61: 16.

Nissinen O., Kukkonen A. \& Kalliainen P. 2010. Bioenergiaa ahdekaunokista? (in Finnish). Maaseudun tiede 67. http://www.mtt.fi/maaseuduntiede/ pdf/mtt-mt-v67n01.pdf (accessed on 15.3.2010)

Nizami A-S., Korres N.E. \& Murphy J.D. 2009. Review of the integrated process for the production of grass biomethane. Environ. Sci. Technol. 43: 8496-8508.

Oslaj M., Mursec B. \& Vindis P. 2010. Biogas production from maize hybrids. Biomass Bioenergy 34: 1538-1545.

Pahkala K. \& Pihala M. 2000. Different plant parts as raw material for fuel and pulp production. Ind. Crops Prod. 11: 119-128.

Pakarinen O., Lehtomäki A., Rissanen S. \& Rintala J. 2008. Storing energy crops for methane production: Effects of solids content and biological additive. Bioresour. Technol. 99: 7074-7082.

Pakarinen A., Maijala P., Stoddard F.L., Santanen A., Tuomainen P., Kymäläinen M. \& Viikari L. 2011a. Evaluation of annual bioenergy crops in the boreal zone for biogas and ethanol production. Biomass Bioenergy 35: 3071-3078.

Pakarinen A., Maijala P., Jaakkola S., Stoddard F.L., Kymäläinen M. \& Viikari L. 2011b. Evaluation of preservation methods for improving biogas production and enzymatic conversion yields of annual crops. Biotechnol. Biofuels 4:20.

Palonen J. \& Oksanen E.H. 1993. Labour, machinery and energy data bases in plant production. Työtehoseuran julkaisuja 330. 
Perstorp Analytical Tecator 1995. Determination of nitrogen according to kjeldahl using block digestion and steam distillation. Tecator application note.

Pobeheim H., Munk B., Johansson J. \& Guebitz G.M. 2010. Influence of trace elements on methane formation from a synthetic model substrate for maize silage. Bioresour. Technol. 101: 836-839.

Pobeheim H., Munk B., Lindorfer H. \& Guebitz G.M. 2011. Impact of nickel and cobalt on biogas production and process stability during semi-continuous anaerobic fermentation of a model substrate for maize silage. Water Res. 45: 781-787.

Pöschl M., Ward S. \& Owende P. 2010. Evaluation of energy efficiency of various biogas production and utilization pathways. Appl. Energy 87(11): 3305-3321.

Prade T., Svensson S-E., Andersson A. \& Mattsson J.A. 2011. Biomass and energy yield of industrial hemp grown for biogas and solid fuel. Biomass Bioenergy 35: 3040-3049.

Prochnow A., Heiermann M., Ploechl M., Linka B., Idler C., Amon T. \& Hobbs P.J. 2009. Bioenergy from permanents grassland - a review: 1. Biogas. Bioresour. Technol. 100: 4931-4944.

Quakernack R., Pacholski A., Techow A., Herrmann A., Taube F. \& Kage H. 2012. Ammonia volatilization and yield response of energy crops after fertilization with biogas residues in a coastal marsh of Northern Germany. Agric., Ecosyst. Environ. 160: 66-74.

Resch G., Held A., Faber T., Panzer C., Toro F. \& Haas R. 2008. Potentials and prospects for renewable energies at global scale. Energy Policy 36(11): 40484056.

Rinne M., Pitkänen T., Nyholm R., Nousiainen J. \& Huhtanen P. 2010. Nurmiheinien ensimmäisen sadon sulavuuden ja sadonmäärän mallit nurmirehuntuotannon hallintaan. (in Finnish). In: Hopponen A. (ed.) Maataloustieteen Päivät 2010 (electronic publishing). Suomen Maataloustieteellisen Seuran tiedotteita no 26. http://www.smts.fi (accessed on 15.5.2013)

Saarinen E., Virkajärvi P., Hyrkäs M., Suomela R., Niskanen M., Salo K. \& Huuskonen A. 2012. Maissin soveltuvuus rehukasviksi Keski-Suomessa. In: Huuskonen A. (ed.) Nautatilojen rehukasvivalikoima laajemmaksi? MTT Raportti 77. (In Finnish) http://www.mtt.fi/mttraportti/pdf/ mttraportti77.pdf (accessed on 5.6.2013)

Saggar S., Hedley C. \& Mackey A.D. 1997. Partitioning and translocation of photosyntetically fixed C14 in grazed hill pastures. Biol. Fert. Soils 25: 152158.

Salter A. 2007. Crops for biogas production; yields, suitability and energy balances. 15th European biomass Conference Berlin 8 May 2007. http://www.ieabiogas.net/_download/publications/workshop/5/salter_contribution_berl in07.pdf (accessed 13.8.2012)

Schattauer A., Adboun E., Weiland P., Plöchl M. \& Heiermann M. 2011. Abundance of trace elements in demonstration biogas plants. Biosystems Eng. 108: 57-65. 
Schittenhelm S. 2008. Chemical composition and methane yield of maize hybrids with contrasting maturity. Eur J Agron 29: 72-79.

Sheldrick R.D. 2000. Sward establishment and renovation. In: Hopkins A. (ed.), Grass, Its Production and Utilization. Blackwell Science Ltd, Cornwall, pp. 1330.

Singh A., Smyth B.M. \& Murphy J.D. 2010. A biofuel strategy for Ireland with an emphasis on production of biomethane and minimization of landtake. Renewable Sustainable Energy Rev. 14: 277-288.

Smyth B.M., Murphy J.D. \& O'Brien C.M. 2009. What is the energy balance of grass biomethane in Ireland and other temperate northern European climates? Renewable Sustainable Energy Rev. 13: 2349-2360.

Smyth B.M., Smyth H. \& Murphy J.D. 2010. Can grass biomethane be an economically viable biofuel for the farmer and the consumer? Biofuels, Bioprod. Biorefin. 4 (5): 519-537.

Somayaji D. \& Khanna S. 1994. Biomethanation of rice and wheat straw. W. J. Microbial. Biotechnol. 10: 521-523.

Subramanian P. \& Sampathrajan A. 1999. Physical and chemical characterization of selected weed species for energy production. Bioresour. Technol. 70: 51-54.

Takashima N. \& Speece R.E. 1990. Mineral requirements for methane fermentation. Crit Rev Biotecnol. 19: 465-479.

Tatah E. 2008. The impacts of genotype and harvest time on dry matter, biogas and methane yields of maize (Zea mays L.). (Dissertation) Justus-Liebig -University Giessen.

TEM 2010. Uusiutuvan energian velvoitepaketti vie kohti vähäpäästöistä Suomea. Ministry of employment and economy (Työ- ja elinkeinoministeriö).

TEM 2013. Strategy review will ensure that the 2020 energy and climate targets are achieved. Ministry of employment and economy (Työ- ja elinkeinoministeriö). http://www.tem.fi/?89521_m=109565\&l=en\&s=2471 (accessed on 15.5.2013)

Thamsiriroj T. \& Murphy J.D. 2009. Is it better to import palm oil from Thailand to produce biodiesel in Ireland than to produce biodiesel from indigenous Irish rapeseed? Appl. Energy 86(5): 595-604.

Thamsiriroj T. \& Murphy J.D. 2011. Modelling mono-digestion of grass silage in a 2 stage CSTR using ADM1. Bioresour. Technol. 102: 948-959.

Thamsiriroj T., Nizami A.S. \& Murphy J.D. 2012. Why does mono-digestion of grass silage fail in long term operation? Appl. Energy 95: 64-76.

Tilman D., Hill J. \& Lehman C. 2006. Carbon-negative biofuels from low-input high-diversity grassland biomass. Science 314: 1598-1600.

Tolera A., Sundstøl F. \& Said A.N. 1998. The effect of stage of maturity on yield and quality of maize grain and stover. Anim. Feed Sci. Technol. 75 (2): 15-168.

Tolera A., Berg T. \& Sundstøl F. 1999. The effect of variety on maize grain and crop residue yield and nutritive value of the stover. Anim. Feed Sci. Technol. 79 (3): 165-177.

Triolo J.M., Pedersen L., Qu H. \& Sommer S.G. 2012. Biochemical methane potential and anaerobic biodegradability of non-herbaceous phytomass in biogas production. Bioresour. Technol. 125: 226-232. 
Tuomisto H. \& Helenius J. 2008. Comparison of energy and greenhouse gas balances of biogas with other transport biofuel options based on domestic agricultural biomass in Finland. Agric. Food Sci. 17: 240-251.

Väisänen A., Laatikainen P., Ilander A. \& Renvall S. 2008. Determination of mineral and trace element concentrations in pine needles by ICP-OES: evaluation of different sample pre-treatment methods. Int. J. Environ. Anal. Chem. 88: 1005-1016.

Vaneeckhaute C., Meers E., Ghekiere G., Accoe F. \& Tack F.M.G. 2013. Closing the nutrient cycle by using bio-digestion waste derivatives as synthetic fertilizer substitutes: A field experiment. Biomass Bioenergy 55: 175-189.

Veste M., Mantovani D., Koning L., Lebzien S. \& Freese D. 2011. Improving nutrient and water use efficiency of IGNISCUM® - a new bioenergy crop. In: Böden verstehen - Böden nutzen - Böden fit machen, 3. - 9. September 2011, Berlin. http:// eprints.dbges.de/739/1/IGNISCUM_DBG2011.pdf (accessed at 12.12.2012)

Viglasky J., Andrejcak I., Huska J. \& Suchomel J. 2009. Amaranth (Amaranthus L.) is a potential source of raw material for biofuels production. Agron. Res. 7: 865-873.

Vintiloiu A., Lemmer A., Oechsner H. \& Jungbluth T. 2012. Mineral substances and macronutrients in the anaerobic conversion of biomass: An impact evaluation. Eng. Life Sci. 12: 287-294.

Weather online 2013. Climate in Germany. http://www.weatheronline.co.uk/ (accessed at 12.05.2013)

Weiland P. 2006. Biomass digestion in agriculture: A successful pathway for the energy production and waste treatment in Germany. Eng. Life Sci. 6: 302309.

Weiland P. 2010. Biogas production: current state and perspectives. Appl. Microbiol. Biotechnol. 85: 849-860.

Yadvika S., Sreekrishnan T.R., Kohli S. \& Rana V. 2004. Enhancement of biogas production from solid substrates using different techniques - a review. Bioresour. Technol. 95: 1-10. 